A major purpose of the Technical Information Center is to provide the broadest dissemination possible of information contained in DOE's Research and Development Reports to business, industry, the academic community, and federal, state and local governments.

Although a small portion of this report is not reproducible, it is being made available to expedite the availability of information on the research discussed herein. 


\title{
SCOPING STUDY OF CASKS SHIPPED FROM THE MRS \\ FACILITY TO VARIOUS REPOSITORY SIT ES
}

\author{
J. A. Bucholz \\ Date Issued: August 1986 \\ Computing and Telecommunications Division \\ at \\ Oak Ridge National Laboratory \\ Post Office Box X \\ Oak Ridge, Tennessee 37831
}

MARTIN MARIETTA ENERGY SYSTEMS, INC.

operating the

Oak Ridge Gaseous Diffusion Plant Oak Ridge National Laboratory

Oak Ridge Y-12 Plant Paducah Gaseous Diffusion Plant

under contract No. DE-AC05-840R21400

for the

U.S. Department of Energy

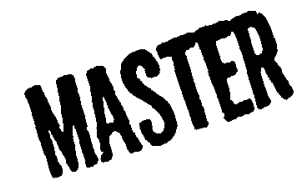


Printed in the United States of America. Available from National Technical Information Service

U.S. Department of Commerce

5285 Port Royal Road. Springfield. Virgınia 22161

N'TIS price codes-Printed Copy: A04: Microfiche A01

This report was prepared as a:l account of work sponsored by an agency of the United States Government. Neither the Unilert States Government nor sny agency thereot, nor a.ny of their employess, manes any warranty. express or implied, or aseumes any legal liability or responsibility for the eccuracy. completeness. Or usefulness of any information, spparatus. product, or process disclosed, or represents that its use would not infringe privately owned rights. Relerence herein to any specific commercial product. process, or service by trade name, irademark. manufacturer, or olmerwise, does not necessarily constitute or imply its endorsement, recommendation, or tavoring by the United Stales Govarnment or eny egency thereof. The views and opinions of acthors expressed herein do not necessarily state or reftect those of the United States Government of any egency thereot. 
TABLE OF CONTENTS

PAGE

LIST OF FIGURES $\ldots \ldots \ldots \ldots \ldots \ldots \ldots \ldots \ldots \ldots \ldots \ldots \ldots \ldots \ldots \ldots \ldots$

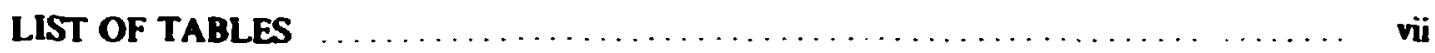

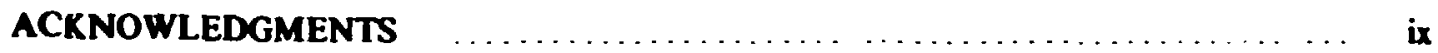

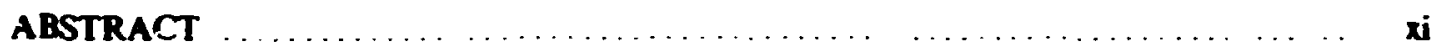

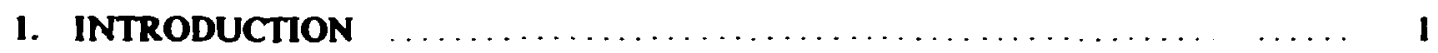

2. DESCRIPTION OF PACKAGES TO BE TRANSPORTED

INSIDE THE SHIPPING CASKS

2.1 SALT REPOSITORY WASTE PACKAGE CONFIGURATIONS

2.2 TUFF REPOSITORY WASTE PACKAGE CONFIGURATIONS

2.3 BASALT REPOSITORY WASTE PACKAGE CONFIGURATIONS

3. GENERIC DESCRIPTION OF CASKS TO BE USED $\ldots \ldots \ldots \ldots \ldots \ldots \ldots \ldots$

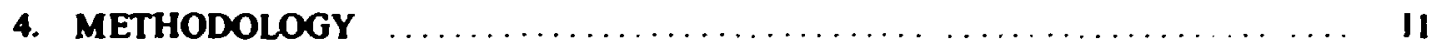

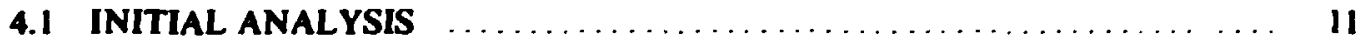

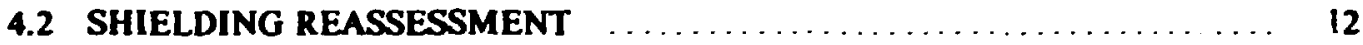

4.3 HEAT TRANSFER CONSIDERATIONS $\ldots \ldots \ldots \ldots \ldots \ldots \ldots \ldots \ldots \ldots$

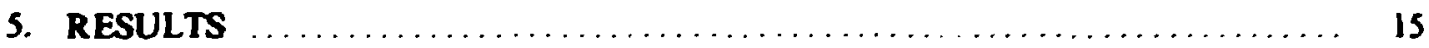

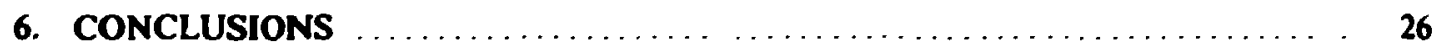

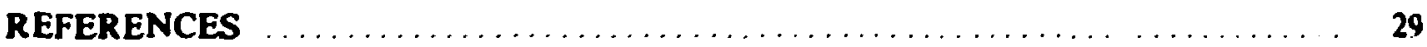

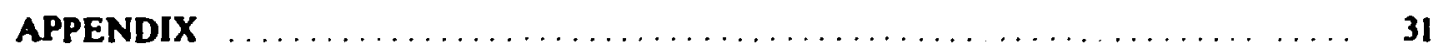




\section{LIST OF FIGURES}

FIGURE

PAGE

1. Salt reference design for a segmented steel canister containing consolidated fuel rods from 12 PWR assemblies or 30 BWR assemblies

2. Thick carbon steel overpact in the Salt reference design

3. Tuff reference design for an crerpack and canister containing consolidated fuel rods from 6 PWR assem jlies

4. Tuff reference desizn for an overpack and canister containing consolidated fuel rods from $14 \mathrm{BWR}$ ascemblies

5. Generic description of a typical shipping cask, as modeled in this study

8

6. Removable aluminum inserts for casks containing $1-12$ cylindrical waste packages

7. A Simplified 2-D KENO IV model of a large U-shielded cask containing 100 consolidated PWR fuel assemblies in 25 thin-walled stcel canisters 


\section{LIST OF TABLES}

TABLE

PAGE

1. Basalt reference designs for thin-walled cartso steel canisters containing consolidated fuel rods from $1,2,3$, or 4 PWR assemblies and/or 2, 4, 7, or 9 BWR assemblies

2. Thicknesses of the main structural components in each type of cask

3. Initial capacities, weights, shield thicknesses, and does rates for 30 representative casks that were selected for more detailed multigroup, 1-D, discrete ordinates shielding analyses

4. Final capacities, weights, shield thicknesses, and dose rates for 30 representative casks tt.: were selected for more detailed multigroup. I-D, discrete ordinates shielding analyses

5. Number of consolidated PWR fuel assemblies that may be shipped in $200,000-1 b$ and $300,000-1 b$ casks

6. Numter of consolidated BWR fuel assemblies that may be shipped in 200,0,0-1b and 300,000-lb casks

7. Gross weight of Salt repository casks vs the number of waste packages

8. Gross weight of Tuff repository casks vs the number of waste packages

9. Gross weight of Basalt repository casks vs the number of waste packages

A.1. Salt reference design; overpack and canister with 12 PWR assemblies/package

A.2. Salt reference design; overpack and canister with 30 BWR assemblies/package

A.3. Salt reference design; bare canister with 12 PWR assemblies/package

A.4. Salt reference design; bare canister with 30 BWR assemblies/package

A.5. Tuff reference design; overpack and canister with 6 PWR assemblies/package

A.6. Tuff reference design; overpack and canister with 14 EWR assemblies/package

A.7. Tuff reference design; bare canister with 6 PWR assemblies/package

A.8. Tuff reference design; bare canister with 14 BWR assemblies/package

A.9. Basalt reference design; overpack only, with 4 PWR ascemblies/package

A.10. Basalt reference design; overpack only, with 9 BWR assemblies/package 
A.11. Basalt reference design; canister only, with I PWR assembly/package $\ldots \ldots \ldots \ldots . \quad 38$

A.12. Basalt reference design; canister only, with 2 BWR assemblies/package . . . . . . . 39

A.13. Basalt reference design; canister ooly, with 2 PWR assemblies; package $\ldots \ldots \ldots \ldots .40$

A.14. Basalt reference design; canister only, with 4 BWR assemblies/package $\ldots \ldots \ldots \ldots$ 4I

A.15. Basalt reference design; canister only, with 3 PWR assemblies/package $\ldots \ldots \ldots \ldots .42$

A.16. Basalt reference design; canister only, with 7 BWR assemt lies/packnge $\ldots \ldots \ldots \ldots .43$

A.17. Basalt reference design; canister only, with 4 PWR assemilies/package $\ldots \ldots \ldots \ldots .44$

A.18. Basalt reference design; canister only, with 9 BWR assemblies/package $\ldots \ldots \ldots \ldots$ 45 


\section{ACKNOWLEDGMENTS}

This study was performed for the Office of Storage and Transportation Systems (OSTS) in the Ofice of Civilian Radioactive Waste Management (OCRWM), U.S. Department of Energy.

The final manuscript was prepared by Lindy Norris of the Computing and Telecommunications Division at Oak Ridge National Lawuratory. 


\begin{abstract}
The objective of this study was to determine the maximum number of specialized repository waste packages that could be shipped from the Monitored Reirievable Storape (MRS) facility in $\mathrm{Pb}$-, Fe-, and U-shielded casks weighing 200,000 or 300,000 lbs. The study acluded 18 different waste packages designed for the Salt. Tuff, and Basalt repositories. Nine of these contained consolidated PWR fuel pins, and nine contained consolidated BWR fuel pins. Discrete ordinates calculations were performed to determine the neutron and gamma shield thicknesses that would ensure a dose rate of $10 \mathrm{millirem} / \mathrm{hr}, 10 \mathrm{ft}$ from the centerline of the cask(s) Over 100 casks of particular interest have been identified, while preliminary design information is also given for 522 castes of potential interest.
\end{abstract}

Relative to the 200,000-1b casks, 50-100\% more fuel may be shipped in the larger $300,000-16$ casks. Placing the spent fuel canisters in overpacks prior to shipment from the MRS will reduce the net payload by $30-50 \%$. The highest-capacity cask/waste package combination studied corresponds to a 300,000-1b U-shielded cask containing 84 consolidated PWR fuel assemblies in 21 canisters, or 171 consolidated BWR fuel assemblies in 19 canisters. Criticality analyses have shown these high-capacity casks to be safely subcritical-even if all the canisters were loaded with unirradiated LWR fuel containing $3.4 \mathrm{wt} \%$ U-235. 


\section{INTRODUCTION}

One of the fundamental purposes for establishing a Monitored Retrievable Storage (MRS) facility is to process spent fuel and repackage it in such a way as to reduce the number of shipments to, and handling requirements at, the chosen repository site.

In order to evaluate the benefits of repackaging the spent fuel at the MRS, it is necessary to determine the net carrying capacity of shipping casks that could be designed for the various types of waste packages used to transfer spent fuel to the repository. Two packaging options exist: (a) the fuel could be disassembled at the MRS, rod-by-rod, and placed in high quality steel canisters; and (b) these canisters might be placed in an overpack before shipment to a repository. Use of overpacks would permit the packages to be placed directly in the geologic repository without any additional processing.

Spent fuel could move from the MRS facility to repositories located in salt, tuff, or basalt formations. Each geologic medium would require a different size canister and a different overpack, if one is to be used. Given the size, weight, and capacity of the canisters and overpacks that would be used for the various repositories, this study employed the Shipping Cask Optimization and Parametric Evaluation (SCOPE) code ${ }^{1}$ to determine the amount of spent fuel that could be shipped in casks weighing 200,000 and 300,000 lbs. The spe.tt fuel was assumed to be ten years old; and the gamma shielding in the casks could be lead, steel, or depleted uranium metal.

\section{DESCRIPTION OF PACKAGES TO BE TRANSPORTED INSIDE THE SHIPPING CASKS}

\subsection{SALT REPOSITORY WASTE PACKAGE CONFI:URATIONS}

Packages fo: the Salt repository may consist of (a) a I-cm-thick carbon steel canister containing spent fuel or (b) a $10-\mathrm{cm}$-thick carbon steel overpack containing a $1-\mathrm{cm}$-thick carbon steel canister with spent fuel. In either case, the thin-walled steel canister has an outside diameter of $62 \mathrm{~cm}$ and an inside diameter of $60 \mathrm{~cm}$. Canisters containing consolidated fuel rods from 12 PWR assemblies are $400 \mathrm{~cm}$ long (including lifting pintle) and weigh $8390 \mathrm{~kg}$ fully loaded, while canisters containing consolidated fuel rods from 30 BWR assemblies are $435 \mathrm{~cm}$ long (including lifting pintle) and weigh $8810 \mathrm{~kg}$ fully loaded. In each case, the canister is internally Hivided into six pie-shaped segments which receive the spent fuel rods (see Fig. 1). The internally segmented canister serves several functions: it facilitates the handling of rods during the consolidation operation; it enhances heat transfer from the center, radially outward; and it enables retrieval of waste after emplacement. The steel overpacks into which the canisters may be placed prior $w$ shipment have an outside diameter of $84.5 \mathrm{~cm}$ and an inside diameter of $64.5 \mathrm{~cm}$. Overpacks containing a canister of PWR spent fuel are $446.5 \mathrm{~cm}$ long (including lifting pintle) and weigh $17,600 \mathrm{~kg}$ fully loaded, while overpacks containing a canister of BWR spent fuel are $481.5 \mathrm{~cm}$ long (including lifting pintle) and weigh $18,700 \mathrm{~kg}$ fully loaded (see Fig. 2). Scoping calculations were performed to determine the net carrying capacity of 200,000-1b and 300,000-lb $\mathrm{Pb}$-, Fe-, and U-shielded shipping casks containing:

(a) overpacks with canisters containing the equivalent of 12 PWR fuel ascemblies,

(b) overpacks with canisters containing the equivalent of 30 BWR fuel assemblies,

(c) bare canisters containing the equivalent of 12 PWR fuel assemblies, and

(d) bare canisters contaiaing the equivalent of $30 \mathrm{BWR}$ fuel assemblies. 
OANL-DWG 85.18134

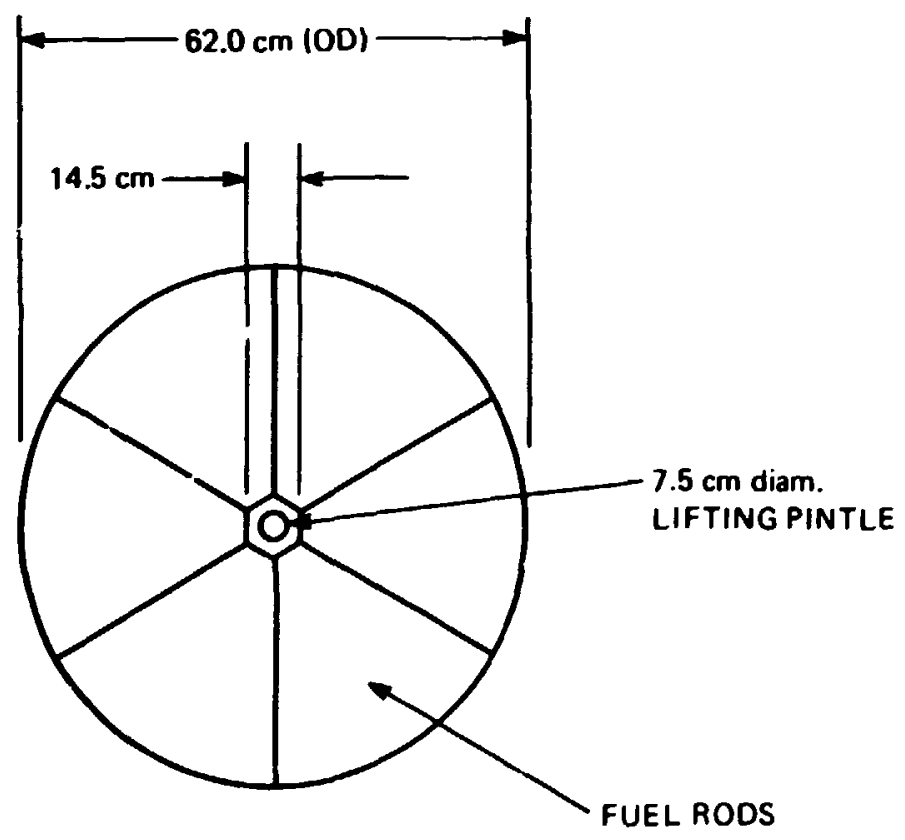

Fig. 1. Salt reference design for a segmented sicel canister containing consolidated fuel rods from 12 PWR assemblies or 30 BWR assemblies. 


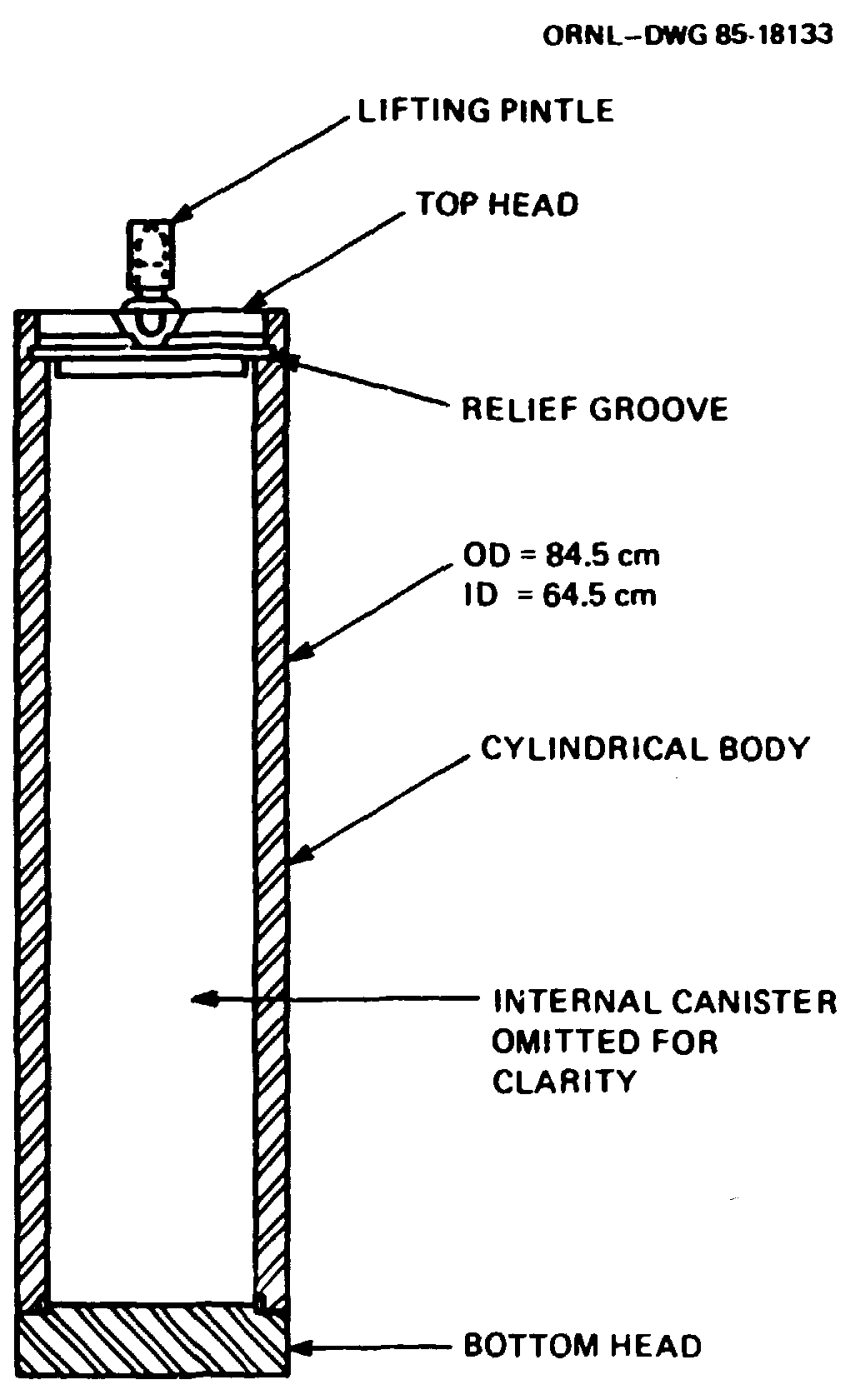

Fig. 2. Thick carbon steel overpack in the Salt reference design. 


\subsection{TUFF REPOSITORY WASTE PACKAGE CONFIGURATIONS}

Packages for the Tuff repcsitory may consist of (a) a $1-\mathrm{cm}$-thick stainless steel canister containing spent fuel or (b) a 1 -cm-thick stainless steel overpack containing a $1 . \mathrm{cm}$-thick stainless steel canister with spent fuel. In each case, thie fuel-bearing canister has an outside diameter of $63 \mathrm{~cm}$ and an inside diameter of $61 \mathrm{~cm}$. Canisters containing corsolidated fuel rods from 6 PWR assemblies are $400 \mathrm{~cm}$ long (including lifting pintle) and weigh $5466 \mathrm{~kg}$ fully loaded, while canisters containing consolidated fuel rods from 14 BWR assemblies are $435 \mathrm{~cm}$ long (iscluding lifting pintle) and weigh $6426 \mathrm{~kg}$ fullj loaded. Canisters for PWR spent fuel are internally divided into three square-shaped segments containing fuel rods (see Fig. 3) while canisters for RWR spent fuel are internally divided into seven square-shaped segments centaining fuel rods (see Fig. 4). This $1-\mathrm{cm}$-thick stainless steel internal structure provides additional mechanical stability and enhances heat transfer. It also provides room for internal poison rods to ensure against criticality. The stainless steel overpacks into which the canisters may be placed prior to shipment have an outside diameter of $70 \mathrm{~cm}$ and an inside diameter of $68 \mathrm{~cm}$. Overpacks containing a canister of PWR spent fuel are $416.5 \mathrm{~cm}$ long (including th.e $16.5-\mathrm{cm}-\mathrm{long}$ lifting pintle) and weigh $6700 \mathrm{~kg}$ fully loaded, while overpacks containing a canister of BWR spent fuel are $491.5 \mathrm{~cm}$ long (including the 16.5-cm-!ung lifting pircle) and weigh $7900 \mathrm{~kg}$ fully loaded (see Figs. 3 and 4). Scoping calculations were rertcrmed to determine the ca-rying capacity of $200,000-1 b$ and $300,000-1 b \mathrm{~Pb}$, Fe-, and U-shielded shipping casks containirg:

(a) overpacks with canisters cuntairing the equivalent of 6 PWR -el assemblies,

(b) overpacks with canisters containing the equivalent of 14 BWR fuel assemblies,

(c) bare canisi-rs containing the equivalent of 6 PWR fuel assemblies, and

(d) bare canister s containing the equivalent of 14 BWR fuel assemblies.

\subsection{BASALT WASTE PACKAGE CONFIGURATIONS}

Packages for the Basalt repository may be one of iwo general types: (a) an 8.3-cm-thick carbon steel overpack (with no inner canister) containing consolidated fucl rods from 4 PWR assemblies or 9 BWR a.semblies, or (b) various types of 0.5 -cm-thick carbon steel canisters containing consolidated fuel rods from 1, 2, 3, or 4 PWR assemblies or 2, 4, 7, or 9 BWR assemblies. The thickwalled overpacks have an outside diameter of $50.3 \mathrm{~cm}$ and an inside diameter of $33.7 \mathrm{~cm}$. Overpacks containing PWR fuel are $405 \mathrm{~cm}$ long (including lifting pintle) and weigh $7000 \mathrm{~kg}$ fully loaded, while overpacks containing BWR fuel are $440 \mathrm{~cm}$ long (including lifting pintle) and weigh $7400 \mathrm{~kg}$ fully loaded. The four different thin-walled canisters included in the reference calculations are described in Table 1 . Scoping calculations were performed to determine the carrying capacity of $200,000-\mathrm{lb}$ and $300,000-\mathrm{lb} \mathrm{Pb}-$, Fe-, and $\mathrm{U}$-shielded shipping casks containing:

(a) overpacks (with no internal canister) containing the equivalent of 4 PWR fuel assemblies,

(b) overpacks (with no internal canister) containing the equivalent of 9 BWR fuel assemblies,

(c) bare 17.5 m-diam canisters containing the equivalent of 1 PWR fuel assembly,

id) bare $17.5-\mathrm{cm}$-diam canisters containing the equivalent of 2 BWR fuel assemblies,

(e) bare $23.3-\mathrm{cm}$-diam canisters containing the equivalent of 2 PWR fuel assemblies, 


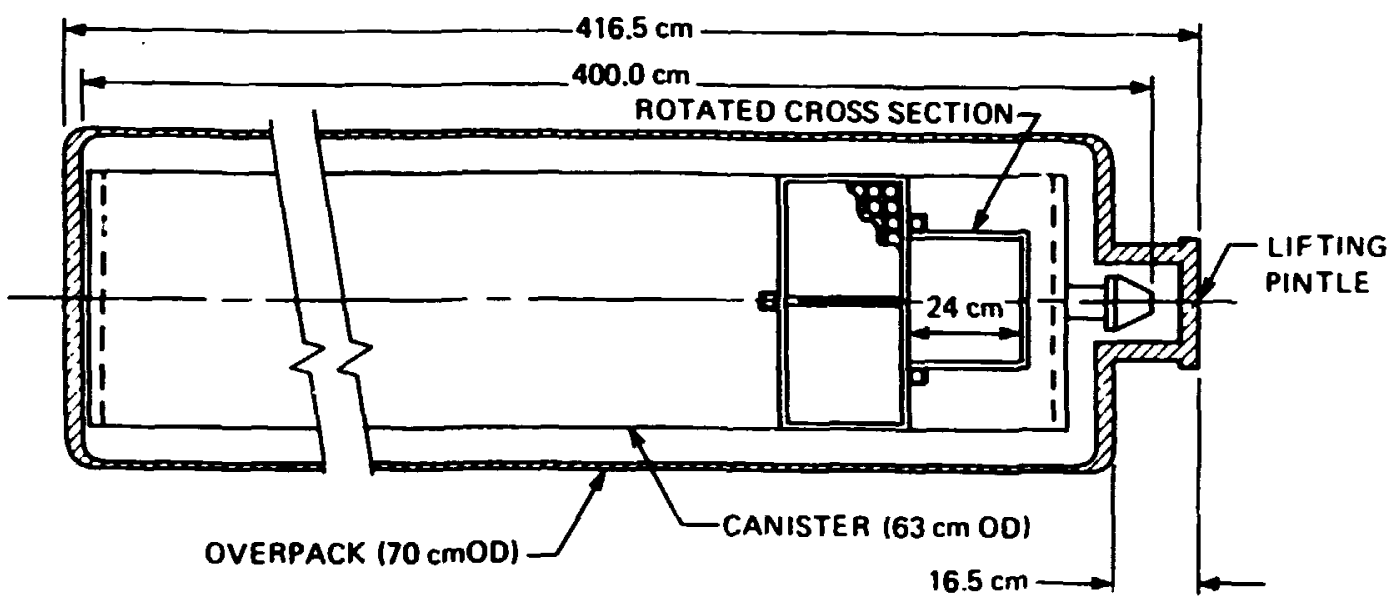

Fig. 3. Tuff reference design for an overpack and canister containing concolidated fuel rods from 6 PWR assemblies.

ORIJL.DWG 85-18138A

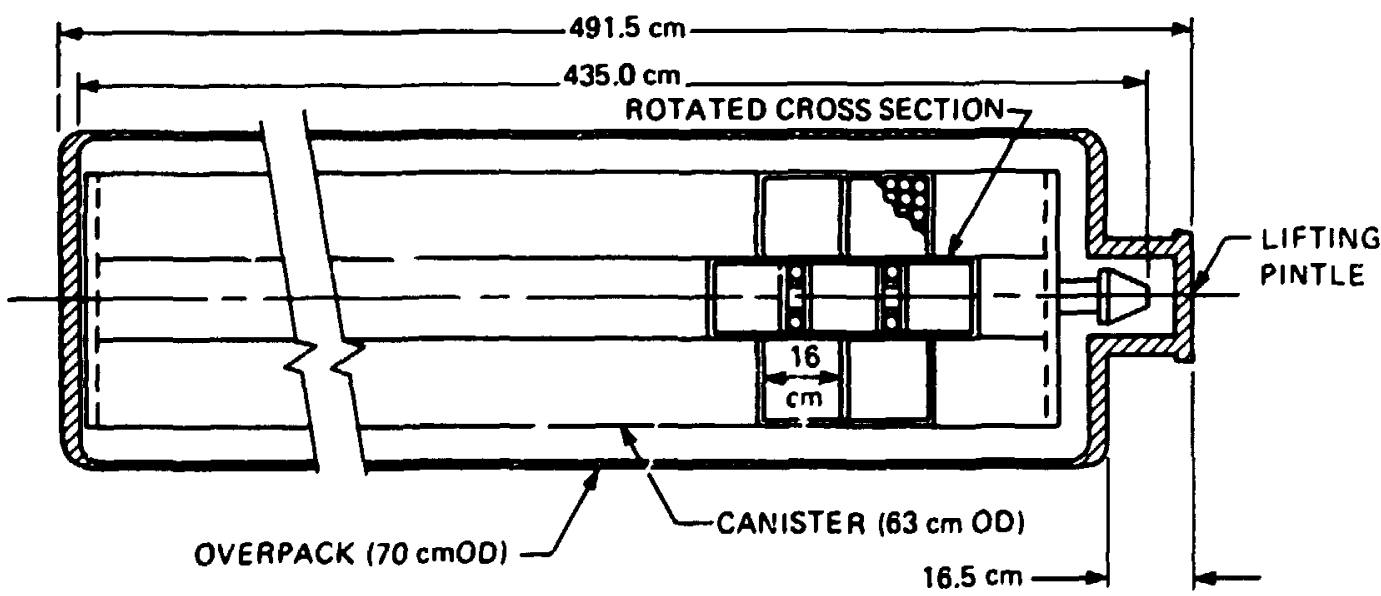

Fig. 4. Tuff reference design for an overpack and canister containing consolidated fuel rorts from 14 BWR assemblies. 
Table 1. Basalt reference designs fc: thin-walled carbon steel canisters containing consolidated fuel rods from $1,2,3$, or 4 PWR ascemblies and/or 2, 4, 7, or 9 BWR assemblies

\begin{tabular}{cccccc}
\hline & & \multicolumn{2}{c}{ Canister of PWR fuel } & \multicolumn{2}{c}{ Canister of BWR Fuel } \\
\cline { 3 - 6 } OD (cm) & ID (cm) & $\mathbf{N}_{\text {nyyyyy}}$ & Weight (kg) & $\mathbf{N}_{\text {noys }}$ & Weight (kg) \\
\hline 17.5 & 16.5 & 1 & 750 & 2 & 795 \\
23.3 & 22.3 & 2 & 1439 & 4 & 1525 \\
28.9 & 27.9 & 3 & 2129 & 7 & 2256 \\
33.0 & 32.0 & 4 & 2511 & 9 & 2661 \\
\hline
\end{tabular}

'Length $=400 \mathrm{~cm}$, including lifting pintle

bength $=435 \mathrm{~cm}$, including lifting pintle 
(f) bare $23.3-\mathrm{cm}-$ diam canisters containing the equivalent of 4 BWR fuel sssembliex,

(g) bare 28.9-cm-diam canisters contrining the equivalent of 3 PWR fuel asemblies,

(b) bare 28.9-cm-diam canisters containing the equivalent of 7 BWR fued assemblies,

(i) bare 33.0-cm-diam canisters containing the equivalent of 4 PWR fuel assemblies, and

(j) bare $33.0-\mathrm{cm}$-diam canisters containing the equivalent of 9 BWR fuel assemblies.

\section{GENERIC DESCRIPTION OF CASKS TO BE USED}

Scoping calculations were performed to determine the net carrying sapacity of $\mathrm{Pb}$-, Fe-, and U-shielded casks designed for each of the 18 different types of waste packages deseribed in Sect. 2. Figure 5 shows a generic diagram of the eype of shipping casks consitered when estimating the overall loaded weight. The gamma shield may be $\mathrm{Pb}, \mathrm{Fe}$, or $\mathrm{U}$-metal between an inner steel shell and an outer steel shell. The neutron shield between the outer steel shell and the outer steel barrel was assumed to be 28.5 vol\% water $(1.0 \mathrm{~g} / \mathrm{cc}), 66.0 \mathrm{vol \%}$ ethylese glycol (1.11 $\mathrm{g} / \mathrm{cc}_{;}, \mathrm{HOCH}_{2} \mathrm{CH}_{2} \mathrm{OH}$ ), and 5.5 vol\% potascium tetraborate $\left(1.74 \mathrm{~g} / \mathrm{cc}_{;} \mathrm{K}_{2} \mathrm{~B}_{2} \mathrm{O}_{7}-8 \mathrm{H}_{2} \mathrm{O}\right)$ made with natural boron. This cernmon mixture of water and antifreeze contains $\sim 1$ wt\% boron. The thicknesses of the inner steel sheil, the outer steel shell, and the outer steel barrel, are given in Table 2 for each type of cask considered. The norninal neutron and gamma shield thicknesses shown in Table 2 are based on an extensive series of weight optimization studies for large casics containing 10-year-cooled PWR spent fuel irradiated to 33,000 MWd/MTIHM.* These optimization studies are described in Sect. IV and Table F.1 of ref. 1. The procodure followed there ascures a dose rate of 10 millirem/hr at a point 10 ft from the cask centerline. Recognizing that the steel caninters and/cr thick-walled steel overpacks in the Salt, Tuff, and Basalt waste packages provide a significant amount of shielding, the actual gamma shield thickneses used in the present study were correspondingly reduced relative to the nominal thicknesses shown in Table 2 . The neutron shield thicknesses were assumed to be unaffected. Additional details are provided in Sect. 4.2 and the Appendix of this reoort. In every case, the thickneseses of the main structural components on either end were assumed to be the same as in the radial direction.

In a few cases involving larger payloads, circumferential cooling fins (spaced every 4 in. axially) were required to orevent the external surface temperature from exceeding $250^{\circ} \mathrm{F}$ when the outside ambient temperature was ascumed to be $130^{\circ} \mathrm{F} .^{\dagger}$ Such fins were only required in about S-10\% of the casea studied. The dimensions of the stainleas steel fins, when required, are shown in tre Appendix.

Within the cask, the cylindrical waste packages were assumed to be placed in separate cavities of a removable aluminum insert. Inserts for casks containing 1-12 cylindrical canisters are illustrated in Fig. 6. The thickneus (t) of the insert between canisters was assumed to be 1 in., as was the outer wall thickness $(w)$ of the insert between the outermost canister and the inner wall of the cask (eee Fig. 6). The diameter $\left(D_{1}\right)$ of the holes containing the canisters was assumed to be 0.25 in. greater than that of the corresponding waste package. The inner diameter of the cask was generally acoumed to be $0.25 \mathrm{in}$. greater than the outside diameter of the insert. (For casks

- Megawatt-days per metric tonne of initial heavy metal.

The internal decay heat load aecociated with the 10-year-cooled spest fuel was 524 watts per PWR fuel ascembly and 168 watts per BWR fuel asembly. BWR fuel assemblies are considerably smaller than PWR ascemblies and are typically irradiated to 27,500 MWd/MTIHM. 
ORNL-OWG U5.18136

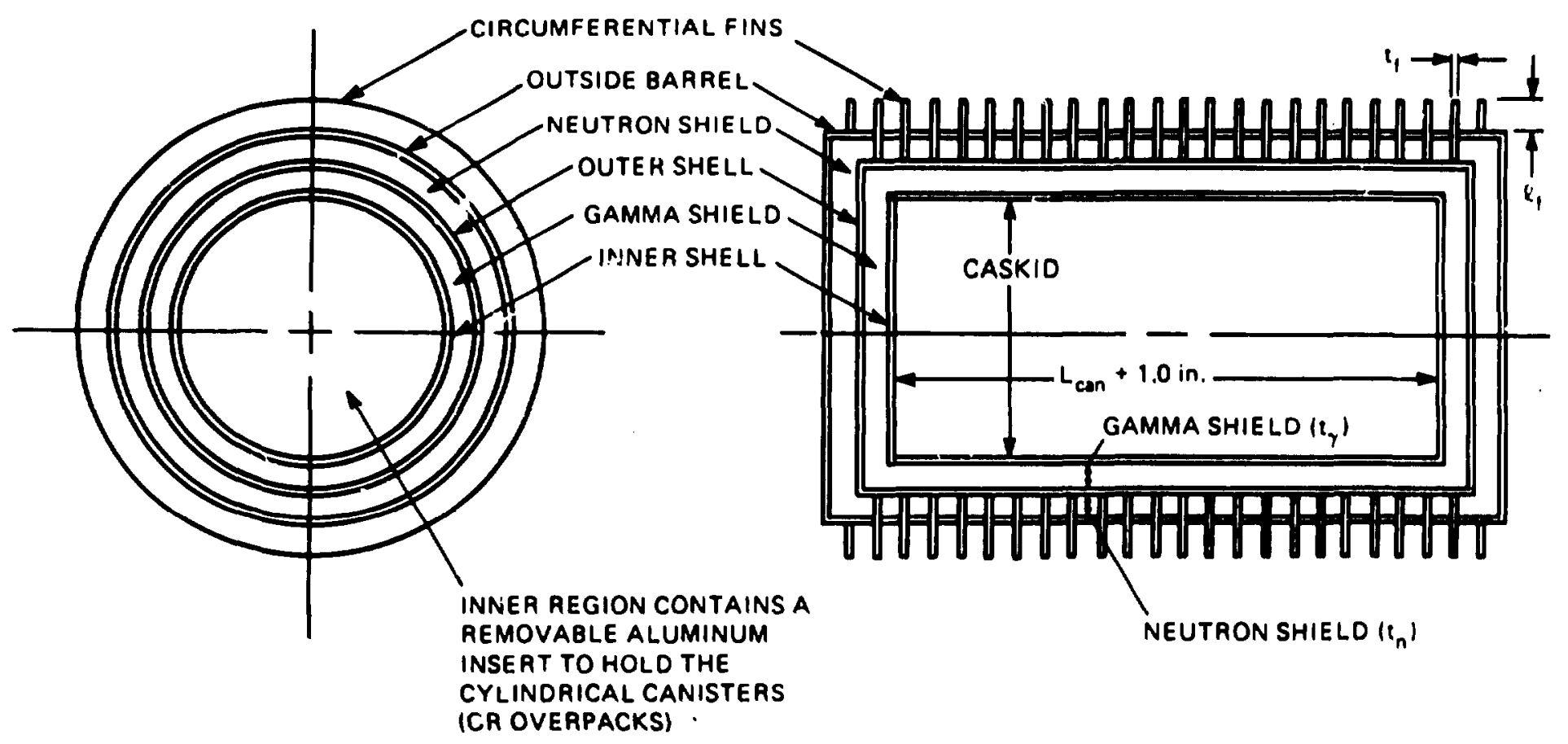

Fig. S. Generic description of a typical shipping cask, as modeled in this study. 
Table 2. Thicknesses" of the main structural composent: in each type of cask

\begin{tabular}{llll}
\hline & Fe Cask & Pb Cask & U Cask \\
\hline Inner steel shell & 0.375 & 1.5 & 0.75 \\
Gamma shield & $9.49^{\mathrm{b}}$ & $4.04^{\mathrm{b}}$ & $2.49^{\mathrm{b}}$ \\
Outer steel shell & 0.375 & 2.0 & 2.0 \\
Neutron shield & 3.75 & 4.25 & 3.47 \\
Outer steel barrel & 0.75 & 0.75 & 0.75 \\
\hline
\end{tabular}

'All thickneases are given in inches.

The actual gamma shield thicknesces used in the present study were reduced relative to this nominal value to acoount for the shielding provided by the thin-walled steel canisters and/or the thick-walled steel overpacks in the Salt, Tuff, and Basalt waste packages. 


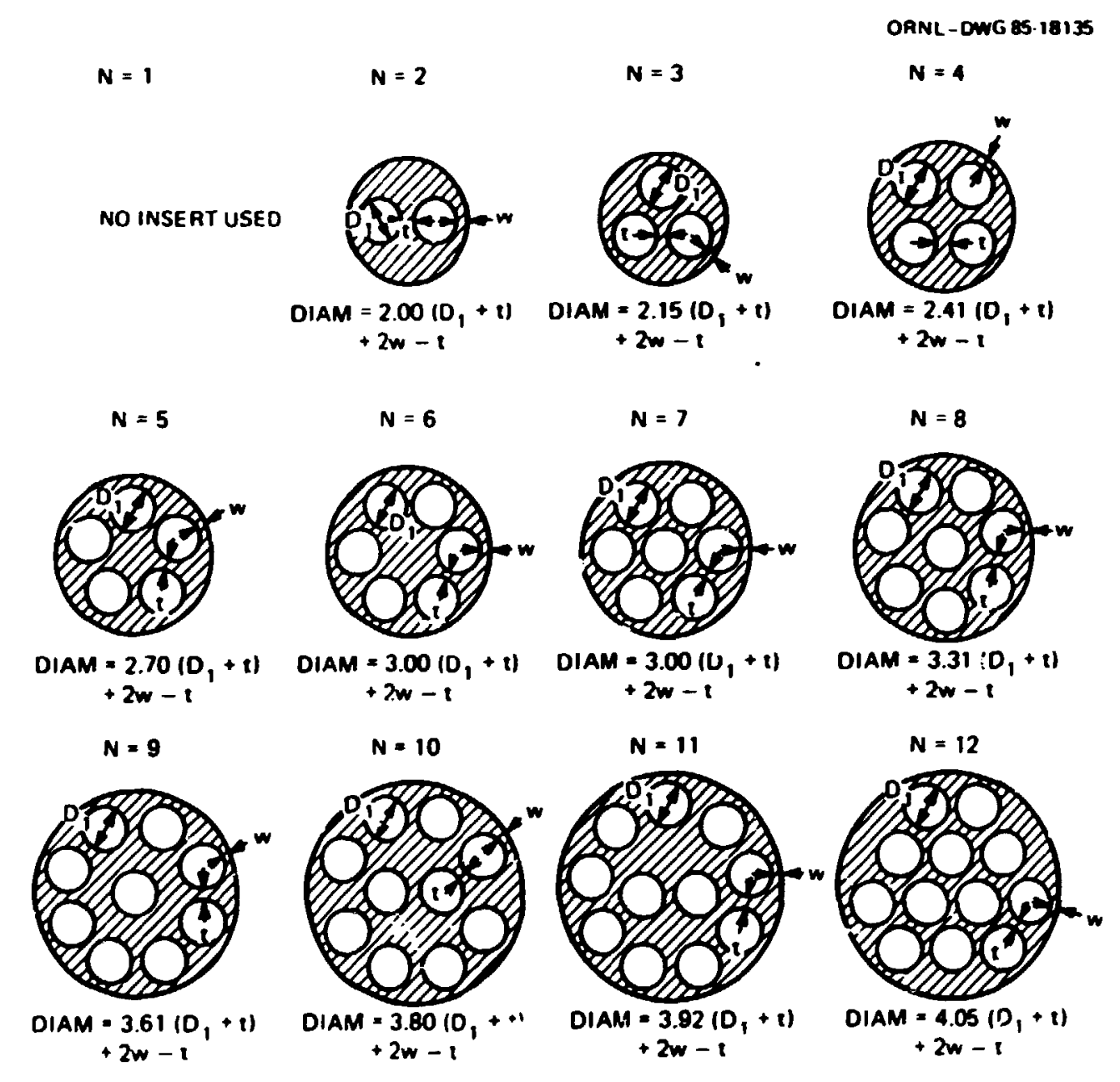

Fig. 6. Rert ovable aluminum inserts for casks containing $1-12$ cylindrical waste packages. 
containing a single waste package, no insert was used, and the inner diameter of the cask was assumed to be 0.2 : in. greater than the outside diameter of the waste pactage.) The length of the cavity inside the cask was always assumed to be 1 in. greater than that of the correspoading waste package.

\section{METHODOLOGY}

Tne objective of this study was to determine the maximum number of waste packages or equivalent spent fuel assemblies that could be shipped in $\mathrm{Pb}$-, Fe-, and $\mathrm{U}$-shielded casks having a gross loaded meight of 200,000 or 300,000 tbs. This determination was to be made for ach of the 18 waste packages described in Sect. 2. To accomplish this, a modified version of the SCOPE code was prepared in which the internal cavity of the cast was defined as being 1 in. longer than the prescribed waste package. Adjusted gamma shiekd thicknesses which accounted for the shielding provided by the thin-walled steel canisters and/or thick-walled steel overpacks were used in the initial SCOPE analysis of the various casks. This initial anslysis provided a rough extimate of the net carrying capacity for each of the various cask/waste pactage combinations. Thirty representative casks of potential interest were then selected for more detailed multigroup shielding analyses using the XSDRNPM and XSDOSE 1-D, discrete ordinates, radiatict transport codea, ${ }^{2,3}$ Based on these results, second-order adjustments were made to the gamma shield thicknesses of the various casks; and another series of 1-D shielding calculations were performed to ensure that the final gamma shield thicknesses did, in fact, yield a dose rate of 10 millirem/hr, $10 \mathrm{ft}$ from the centerline. A final series of SCOPE analyses were then performed (using the finalized gamma shield thicknesses) to determine the net carrying capacity for each of the various cask/waste package combinations. Because the results for casks containing compacted BWR spent fuel were considered of marginal importance in this initial study, the gamma shield thicknesses for the BWR casks were assumed to be the same as those for similar PWR casks.

\section{I INITIAL ANALYSIS}

The SCOPE code' requires, as input, the thickness of the neutron and gamma shields as a function of the number of waste packages each type of cask. Because of the large amount of consolidated spent fuel contained in these particular casks and the spatial self-shielding afforded by the fuel itself, it was anticipated that the actual neutron and gamma shield thicknesses would be relatively insensitive to the number of waste packages in the cask. These parameters were therefore treated as constants in the initial analysis. Nominal neutron and gamma shield thicknesses based on a cask containing 26, 10-year-cooled PWR assemblies are given in Table 2. These thicknesses are based on an extensive series of weight optimization studies' for large casks containing l0-yearcooled PWR spent fuel irradiated to 33,000 MWd/MTIHM. These optimization studies used the XSDRNPM and XSDOSE 1-D discrete ordinates shielding codes ${ }^{2,3}$ and are described in Sect. IV and Table F.I of ref. I. The resulting shield thickneseses typicalty yield a dose rate of 10 millirem/hr at a point $10 \mathrm{ft}$ frosn the centerline of the cask. Recognizing that the steel canisters and/or thick-walled steel overpacks comprising the Salt. Tuff, or Basalt waste packages may provide a significant amount of shieldis:g, the actual Fe giama shield thicknesces used in this study were correspondingly reduced relative to the nominal thicknesses shown in Table 2. Likewise, the $\mathrm{Pb}$ shields were reduced by the equivalent amount of $\mathrm{Pb}(1.0 \mathrm{~cm} \mathrm{Fe}=0.598 \mathrm{~cm} \mathrm{~Pb})$, and the $U$-metal shields were reduced by the equivalent amount of U-metal $(1.0 \mathrm{~cm} F e=0.331 \mathrm{~cm}$ U-metal). The neutron shield thicknesses were assumed to be unaffected. This procedure was expected to maintain a dose rate of approximately $10 \mathrm{millirem} / \mathrm{hr}$ at a point 10 ft from the cask centerline. IThe nominal neutron and gamma shield thicknestes for the BWR casks were assumed to be the same as those for similar PY R casks. In practice, casks containing BWR spent fuel may require slightly less shielding (see Tables $C . I$ and $C .2$ of ref. 1).] 


\subsection{SHIELDING REASSESSMENT}

Using the approximate gamma shield thicknesses described in Sect. 4.1. the SCOPE code was used to survey a large number of 200,000-1b and 300,000-1b Pb-, Fe-, and U-shielded casts for each of the 18 waste pactages described in Sect. 2. rom the large field of casts survejed, 30 representative cask/waste pactage configurations were selected for more detailed shielding analysea. Table 3 describes each of the 30 cask/waste pactage configurations selected. It also shows the number of waste pactages contained in each given cast; the overall weight of the loaded cast; the actual thickness of the gamma shiekd resulting from the initial approximations described in Sect. 4.1; and the actual calculated dose rate, $10 \mathrm{ft}$ from the cent srline of the cast. These calculated dose rates were determined using the SCALE system" Shielding Analysis Sequence number 1 (i.e., the SASI control module'), the SCALE 22n-18r cross-section library with the ANSI standard flux-to-dose conversion factors, and the neutron and gamma sorrce spectra for 10-year-cooled PWR spent fuel irradiated to 33,000 MWd/MTIHM, as given in Appeadix C of ref. 1. The SASI control module employs the XSDRNPM discrete ordinates code ${ }^{2}$ to perform the radiation transport calculation throughout the cask and employs the XSDOSE code ${ }^{3}$ io calculate the resulting dose rate at the midplane of the cask, $10 \mathrm{ft}$ from the centerline.

It can be seen from Tabte 3 that the approximate gamma shield thictnesses used in the initial analysis yielded dose rates that were generally between 6 and 9 millirem/hr, atthough some were as low as 4.7 millirem/hr and ochers were as high as 13.2 millirem/hr. So that comparisons of net carrying capacities could be made on a fair basis among the various casks, second-order adjustmeats of the various gamma shields were then made so that each cast yielded a dose rate of 10 millirem/hr. To accomplish this, the doce rate was assumed to vary as $D=D_{\text {oexp }}\left[-\Sigma_{r} \Delta r\right.$, where $\Sigma_{\gamma}$ is the differential dose attenuation coefficient for the gamma shield; and $\Delta r$ is the change in the gamma shield thickness. From earlier gamma shield seasitivity studiea for similar casks (see Sect. IV, Appendix D, and Tables D.7-D.9 of ref. 1), it was estimated that for Fe, $\Sigma_{Y}=$ 0.9976/in.; for $\mathrm{Pb}, \Sigma_{\gamma}=1.5378 /$ in.; and for $U$ metal, $\Sigma_{\gamma}=2.7909 /$ in. Second-order adjustments to the actual gamma shield thicknesses were then made using these data. For the four Salt repository castes containing a siogle waste package, the gamma shield thicknrsues could be reduced by about 0.5 in. In the otber 26 cases studied, the required second-order adjustments ranged from -0.26 in. to +0.13 in. These revised gamma shield thicknesses were then used in the SCOPE code to determine their effect on the gross loaded weight of the various casks. The multigroup discrete ordinates shielding analysis was also repeated for each of these 30 cask, using the revised gansma shield thicknesses. The resilts of this reevaluation are shown in Table 4. Note that the gross weight of most casks changed by no more than 3000-5000 lbs and that the dose rates in each case were found to be between 9.8 and $10.2 \mathrm{millirem} / \mathrm{hr}, 10 \mathrm{ft}$ from the centerline.

\subsection{HEAT TRANSFER CONSIDERATIONS}

Heat transfer considerations were generally considered an ancillary part of this initial scoping study. The SCOPE code' does, however, calculate the steady-state temperature distribution throughout the cask; it also performs a complete I-D space/time transient thermal analysis following a postulated 30 -min. fire. The results of these calculations are reported in the Appendix. It should be noted, however, that the algorithm used by the code for calculating the maximum fuel pin temperatures may be very conservative when applied to consolidated spent fuel. The code assumes, for example, that the fuel pins are dispersed within the canister or overpack in a square array, and calculates the maximum fue! pin temperature using the Wooton-Epstein correlation in which the prima.y mode of heat transfer is thermal radiation, with a small correction for thermal convection within the fuel bundle. For tightly compacted spent fuel (and for canisters with radial conductors, as in the Salt waste canister), the Wooton-Epstein equation will yield a very conserva. tive reault, such that the calculated fuel pin clad temperatures are well above those that one would 
Table 3. Initial capacities, wrights, shield thicknessea, and dose rates

for 30 representative casks that were selected for more detailed, multigroup, I-D, discrete ordinates shielding analyses

\begin{tabular}{|c|c|c|c|c|c|c|c|c|c|c|c|c|c|c|}
\hline Repsestory desion & Iype & of peckege & & & Te eask & & & Po $\mathrm{c}$ & Eask & & & & eank & \\
\hline selt design & & & $\mathbf{p}$ & - wu.v & - t.tet & $-d . d d^{2}$ & p & $-w w w . v$ & $-t, t t$ & $-d . d d^{2}$ & a & - wwu,v & $=t . t t$ & $-d . d d^{2}$ \\
\hline 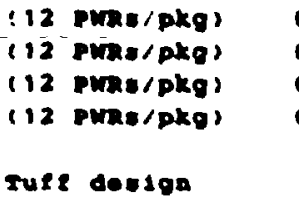 & $\begin{array}{l}\text { Overpeck } \\
\text { overpack } \\
\text { candater } \\
\text { cendeter }\end{array}$ & $\begin{array}{l}\text { o condeter } \\
\text { ondoter } \\
\text { ondy } \\
\text { ondy }\end{array}$ & $\begin{array}{l}1 \\
3 \\
1 \\
3\end{array}$ & $\begin{array}{l}=93.4 \\
=260.4 \\
=\quad 96.7 \\
=\quad 209.1\end{array}$ & $\begin{array}{l}-5.16 \\
=5.16 \\
=9.10 \\
=9.10\end{array}$ & $\begin{array}{l}=5.76 \\
=\quad 1.62 \\
=\quad 5.34 \\
=\quad 9.01\end{array}$ & $\begin{array}{l}1 \\
3 \\
1 \\
3\end{array}$ & $\begin{array}{l}=90.4 \\
-\quad 263.0 \\
=\quad 11.2 \\
-\quad 19.1 .0\end{array}$ & $\begin{array}{l}=1.45 \\
=1.45 \\
=3.00 \\
=3.00\end{array}$ & $\begin{array}{l}=1.12 \\
=\quad 6.96 \\
=\quad 5.30 \\
=\quad 1.90\end{array}$ & $\begin{array}{l}1 \\
3 \\
1 \\
3\end{array}$ & $\begin{array}{l}=\quad 96.5 \\
=252.4 \\
=\quad 66.6 \\
=177.5\end{array}$ & $\begin{array}{l}=1.05 \\
=1.05 \\
=2.36 \\
=2.36\end{array}$ & $\begin{array}{l}=5.11 \\
=\quad 7.30 \\
=\quad 3.50 \\
=\quad 9.06\end{array}$ \\
\hline 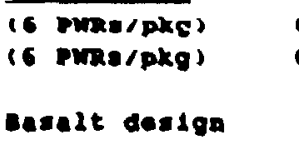 & $\begin{array}{l}\text { Ovarpack } \\
\text { cansater }\end{array}$ & $\begin{array}{l}\text { ondy candeter } \\
\text { only }\end{array}$ & 3 & $\begin{array}{l}-294.1 \\
-250.5\end{array}$ & $\begin{array}{r}-9.70 \\
-9.10\end{array}$ & $\begin{array}{l}=7.93 \\
=\quad 7.90\end{array}$ & $\begin{array}{l}3 \\
3\end{array}$ & $\begin{array}{l}-270.2 \\
-230.6\end{array}$ & $\begin{array}{l}-3.37 \\
-3.100\end{array}$ & $\begin{array}{l}=7.30 \\
=7.03\end{array}$ & 3 & $\begin{array}{l}-235.1 \\
-220.7\end{array}$ & $\begin{array}{l}-2.23 \\
-2.36\end{array}$ & $\begin{array}{l}=1.04 \\
-\quad 1.03\end{array}$ \\
\hline 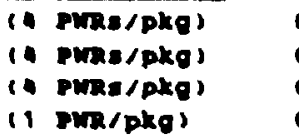 & $\begin{array}{l}\text { overpack } \\
\text { Candater } \\
\text { candeter } \\
\text { Candater }\end{array}$ & $\begin{array}{l}\text { oxly } \\
021 y \\
0 x 1 y \\
\text { oxly }\end{array}$ & $\begin{array}{l}10 \\
10 \\
15 \\
54\end{array}$ & $\begin{array}{l}-327.0 \\
-209.1 \\
-272.9 \\
-206.2\end{array}$ & $\begin{array}{l}=6.22 \\
=9.29 \\
=9.29 \\
-9.29\end{array}$ & $\begin{array}{l}-1.91 \\
-\quad 9.56 \\
-11.33 \\
-11.00\end{array}$ & $\begin{array}{l}10 \\
10 \\
17 \\
59\end{array}$ & $\begin{array}{l}-317.0 \\
-192.0 \\
-270.2 \\
-295.7\end{array}$ & $\begin{array}{l}-2.09 \\
-3.92 \\
-3.92 \\
-3.92\end{array}$ & $\begin{array}{l}-\quad 6.53 \\
=\quad 9.49 \\
-12.25 \\
=11.41\end{array}$ & $\begin{array}{l}10 \\
10 \\
19 \\
66\end{array}$ & $\begin{array}{l}-305.1 \\
-180.4 \\
-274.5 \\
-288.0\end{array}$ & $\begin{array}{l}=1.01 \\
=2.43 \\
=2.03 \\
=2.43\end{array}$ & $\begin{array}{l}-\quad 6.90 \\
=\quad 1.60 \\
-13.10 \\
-12.24\end{array}$ \\
\hline
\end{tabular}

a - aumber of raste packages is tae giver cask.

- overall velobt of the loaded cask (268.4 - 260,400 1bs).

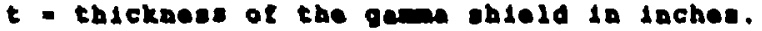

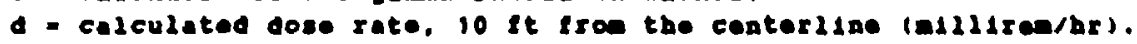


Table 4. Final capacities, weights, shich thicknessas, and dose rates

for 30 representative casks that were selocted for more detailed, multigroup, $1-D$, discrete ordinates shielding analyses

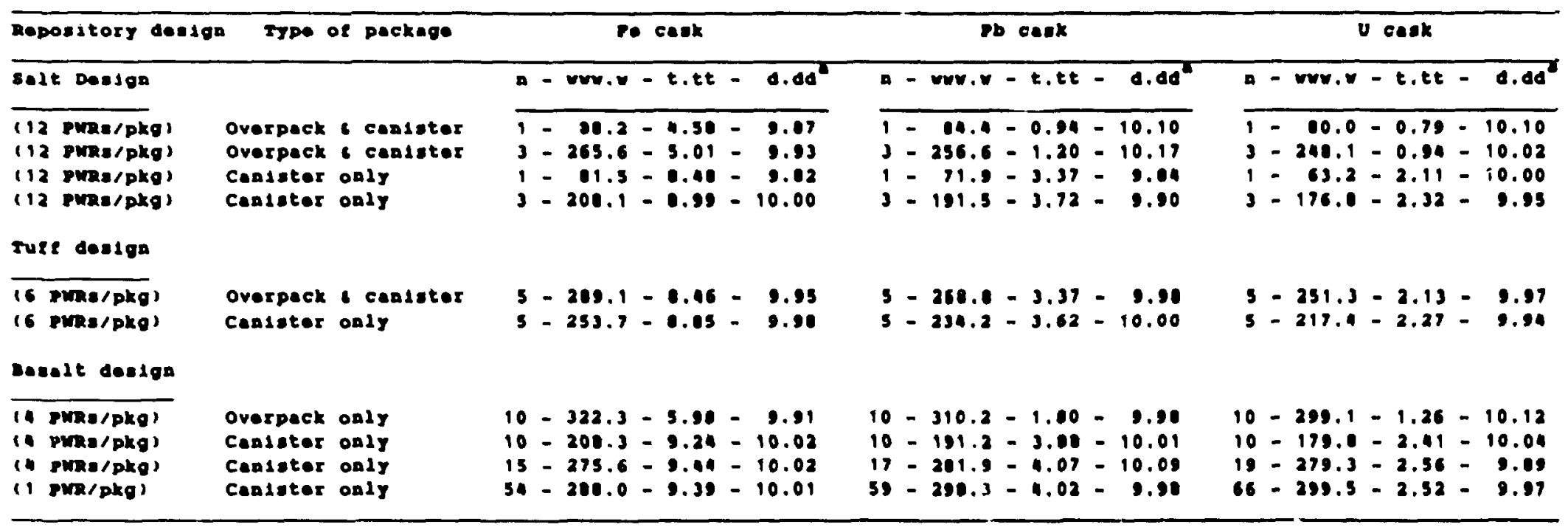

"a = number of waste packeges in the given ceak.

- overall weloht of the loeded cauk (265.6 $=263,0002$ be)

t = tbicknose of the gana sbield la inches.

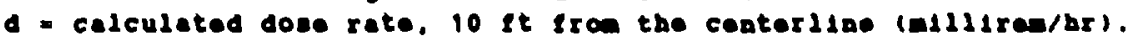


realistically expect. Even so, the calculated steady-state temperatures are generally well below the limit at which oxidation of the fuel becomes a significant problem. In those few cases where the calculated temperatures do approach this limit (see the Salt case, with canisters only, with 12 PWR assemblies per canister), a more rigorous thermal analysis may show the actual temperatures to be well below the iimit.

\section{RESULTS}

Table 5 shows the number of consolidated PWR fuel assemblies that may be shipped in $200,000-1 b$ and $300,000-1 b \mathrm{~Pb}-, \mathrm{Fe}$-, and U-shielded casks utilizing the various repository waste packages described in Sect. 2, the cask configurations described in Sect. 3, and the refined gamma shiefd thicknesses described in Sect. 4. Table 6 shows the number of consolidated BWR fuel assemblies that may be shipped in similar casks whose waste packajes (that is, canisters and/or overpacts) have been designed for BW'R fuel. [Because these latter results were deemed of secondary importance, the corresponding gamma shield thicknessers were conservatively assumed to be the same as those for casks cuntaining PWR spent fuel.] In general, it should be noted that (a) $50-100 \%$ more spent fuel may be shipped in the larger 300,000-lb casks; (b) placing the spent fuel canisters in overpacks prior to shipment from the MRS will reduce the net carrying capacity by about 30-50\%; (c) for the higher capacity packages used by the Salt and Tuff repositories, the $\mathrm{Pb}$ and $U$ metal casks offer equal carrying capacities, while that of the Fe casks is generally less; and (d) for the smaller packages used by the Basalt req ository, the U metal casks can carry more spent fuel than the $\mathrm{Pb}$ casks which, in turn, can carry n ore spent fuel than the $\mathrm{Fe}$ casks. [Even for the larger packages used by the Salt and Tuff repositories, the $U$ metal casks generally weigh somewhat less than a $\mathrm{Pb}$.asik of equal capacity.] With respect to specific cask/waste package configurations, two points should be noted: (a) In the case of the larger overpacks used in the Salt and Tuff designs, the combined weight of two casks, each containing one waste package and each weighing less than $100,000 \mathrm{lbs}$, would be less than that of a conventional cylindrical cask containing two waste packages (see Tables 7 and 8). Further reductions in the overall weight might therefore be realized through the use of a rectangular or elliptically shaped cask containing two such waste packages. (b) The highest capacity cask/waste package combination studied correponds to a $300,000-1 b$ U-shielded cask containing 84 PWR fuel assemblies in 21 thin-walled steel canisters, or 171 BWR fuel assemblies in 19 thin-walled steel canisters. As noted below, KENO IV Monte Carlo criticality analyses have shown these high-capacity casks to be safely subcritical-even if all ci the canisters were loaded with unirradiated PWR fuel pins containing 3.4 wt\% U-235.

The information contained in Tables 5 and 6 is useful but incomplete. Because of elementary geometric constraints on the internal loading pattern, the inside diameter of a cask and its overall weight are nonuniform functions of the number of waste packages contained therein. Slight increases in the allowable weight of a cask may have a significant effect on the net carrying capacity in some cases while having no effect in other cases. Tables 7, 8, and 9 therefore show the groas (loaded) weight of Salt, Tuff, and Basalt repository casks as a function of the number of waste packages in the cask and the equivalent number of consolidated fuel assemblies in the cask. They also show the actual amount of $\mathrm{Pb}, \mathrm{Fe}$, or $\mathrm{U}$-metal shielding finally used for each of the 18 waste package configurations described in Sect. 2. From this more detailed information it may be seen that a U-metal cask of a given capacity will always weigh less than a $\mathrm{Pb}$ cast of the same capacity, and that a Pb cask will always weigh less than an Fe cask. While two casks may have the same net carrying capacity, the differences in the gross weight may be significant in some cases. It should also be noted that two U-shielded carks, each carrying one Salt overpack, would have a combined weight of 160,000 lbs while a single, cylindrically shaped U-shielded cask carrying two Salt overpacks would have a weight of 206,200 lbs. Presumably a single, rectangular or elliptically shaped U-shielded cask carrying two Salt overpacks would weigh less than 160,000 lbs.

Tables 7, 8, and 9 briefly describe 522 casks of potential interest corresponding to the 18 repository waste packages defined in Sect. 2. Tabies A.1 A.18 of the Appendix show the more detailed 
Table 5. Number of consolidated PWR fuel assemblies that may be shipped in 200,000-1b and 300,000-1b casks

\begin{tabular}{|c|c|c|c|c|c|c|c|}
\hline \multirow[b]{2}{*}{ Fepocitary design } & \multirow[b]{2}{*}{ Typ: of packare } & \multicolumn{3}{|c|}{$200,000-1 b$ casts } & \multicolumn{3}{|c|}{$300,000-16$ casks } \\
\hline & & $\mathrm{Fe}$ & Pb & $\mathbf{U}$ & $\mathrm{Fe}$ & Pb & $\mathbf{U}$ \\
\hline \multicolumn{8}{|l|}{ Sah dexign } \\
\hline $\begin{array}{l}\text { (12 PWRs/pts) } \\
\text { (12 PWRs/ptg) }\end{array}$ & $\begin{array}{l}\text { Overpect \& canister } \\
\text { Canister only }\end{array}$ & $24^{2}$ & $\begin{array}{l}24^{2} \\
36\end{array}$ & $\begin{array}{l}24^{x} \\
36\end{array}$ & $\begin{array}{l}36 \\
60\end{array}$ & $\begin{array}{l}36 \\
60\end{array}$ & $\begin{array}{l}48 \\
72\end{array}$ \\
\hline \multicolumn{8}{|l|}{ Tuff dexign } \\
\hline $\begin{array}{l}\text { (6 PWRs/ples) } \\
\text { (6 PWRs/plcs) }\end{array}$ & $\begin{array}{l}\text { Overpeck anister } \\
\text { Canister only }\end{array}$ & $\begin{array}{l}12^{2} \\
18\end{array}$ & $\begin{array}{l}18 \\
24\end{array}$ & $\begin{array}{l}18 \\
24\end{array}$ & $\begin{array}{l}30 \\
42\end{array}$ & $\begin{array}{l}30 \\
42\end{array}$ & $\begin{array}{l}+2 \\
48\end{array}$ \\
\hline \multicolumn{8}{|l|}{ Basalt dexign } \\
\hline $\begin{array}{l}\text { (4 PWRs/pks) } \\
\text { (4 PWRs/pks) } \\
\text { (3 PWRs/pks) } \\
\text { (2 PWRs/pts) } \\
\text { (1 PWR/pke) }\end{array}$ & $\begin{array}{l}\text { Overpact only } \\
\text { Canister only } \\
\text { Canister only } \\
\text { Canister only } \\
\text { Canister oaly }\end{array}$ & $\begin{array}{l}20 \\
36 \\
36 \\
34 \\
31\end{array}$ & $\begin{array}{l}20 \\
40 \\
39 \\
38 \\
34\end{array}$ & $\begin{array}{l}24 \\
48 \\
42 \\
42 \\
39\end{array}$ & $\begin{array}{l}36 \\
68 \\
63 \\
62 \\
55\end{array}$ & $\begin{array}{l}36 \\
76 \\
69 \\
68 \\
61\end{array}$ & $\begin{array}{l}40 \\
84 \\
75 \\
76 \\
69\end{array}$ \\
\hline
\end{tabular}

Una 2 casks, cach contrining I waxte pacterge, and cach weighing less than 100,000 lba; alterately, one may use a single rectaggular or elliptically shaped cask containing 2 warte packages.

Table 6 . Number of consolidated BWR fuel assemblies that may be shipped in 200,000-1b and 300,000-1b casks

\begin{tabular}{|c|c|c|c|c|c|c|c|}
\hline \multirow[b]{2}{*}{ Reprsitory desipn } & \multirow[b]{2}{*}{ Type of peckate } & \multicolumn{3}{|c|}{$200,000-1 \mathrm{~b}$ cauks } & \multicolumn{3}{|c|}{$300,000-16$ casks } \\
\hline & & $\mathbf{F e}$ & $\mathbf{P b}$ & $\mathbf{U}$ & Fe & $\mathbf{P b}$ & $\mathbf{U}$ \\
\hline \multicolumn{8}{|l|}{ Salt deaign } \\
\hline $\begin{array}{l}\text { (30 BWRs/pks) } \\
(30 \mathrm{BWRs} / \mathrm{pks})\end{array}$ & $\begin{array}{l}\text { Overpeck \& canister } \\
\text { Canister only }\end{array}$ & $\begin{array}{l}60^{2} \\
60^{2}\end{array}$ & $\begin{array}{l}60^{2} \\
90\end{array}$ & $\begin{array}{l}60^{\circ} \\
90\end{array}$ & $\begin{array}{r}90 \\
150\end{array}$ & $\begin{array}{r}90 \\
150\end{array}$ & $\begin{array}{r}90 \\
150\end{array}$ \\
\hline \multicolumn{8}{|l|}{ Tuff deaign } \\
\hline $\begin{array}{l}\text { (14 BWRs/pkg) } \\
\text { (14 BWRs/pkg) }\end{array}$ & $\begin{array}{l}\text { Overpeck canister } \\
\text { Caniater only }\end{array}$ & $\begin{array}{l}28^{2} \\
28^{2}\end{array}$ & $\begin{array}{l}28^{2} \\
42\end{array}$ & $\begin{array}{l}28^{2} \\
42\end{array}$ & $\begin{array}{l}56 \\
70\end{array}$ & $\begin{array}{l}56 \\
98\end{array}$ & $\begin{array}{l}70 \\
98\end{array}$ \\
\hline \multicolumn{8}{|l|}{ Bacalt dexign } \\
\hline $\begin{array}{l}\text { (9 BWRs/pks) } \\
\text { (9 BWRs/pks) } \\
\text { (7 BWRs/pks) } \\
\text { (4 BWRs/pks) } \\
\text { (2 BWRs/pks) }\end{array}$ & $\begin{array}{l}\text { Overpack only } \\
\text { Canister only } \\
\text { Canister only } \\
\text { Canister only } \\
\text { Canister only }\end{array}$ & $\begin{array}{l}45 \\
72 \\
70 \\
60 \\
56\end{array}$ & $\begin{array}{l}45 \\
81 \\
84 \\
68 \\
64\end{array}$ & $\begin{array}{l}45 \\
99 \\
91 \\
80 \\
70\end{array}$ & $\begin{array}{l}72 \\
144 \\
140 \\
120 \\
110\end{array}$ & $\begin{array}{r}81 \\
153 \\
154 \\
128 \\
112\end{array}$ & $\begin{array}{l}81 \\
171 \\
161 \\
140 \\
126\end{array}$ \\
\hline
\end{tabular}

Unes 2 cack, each containing I waste packare, and each weighing leas than $100.000 \mathrm{lbs}$; alternately, one may use a single rectangular or elliptically shaped cusk containing 2 waste packages. 
Table 7. Gross woight of Salt repository casks vs the number of waste packagese

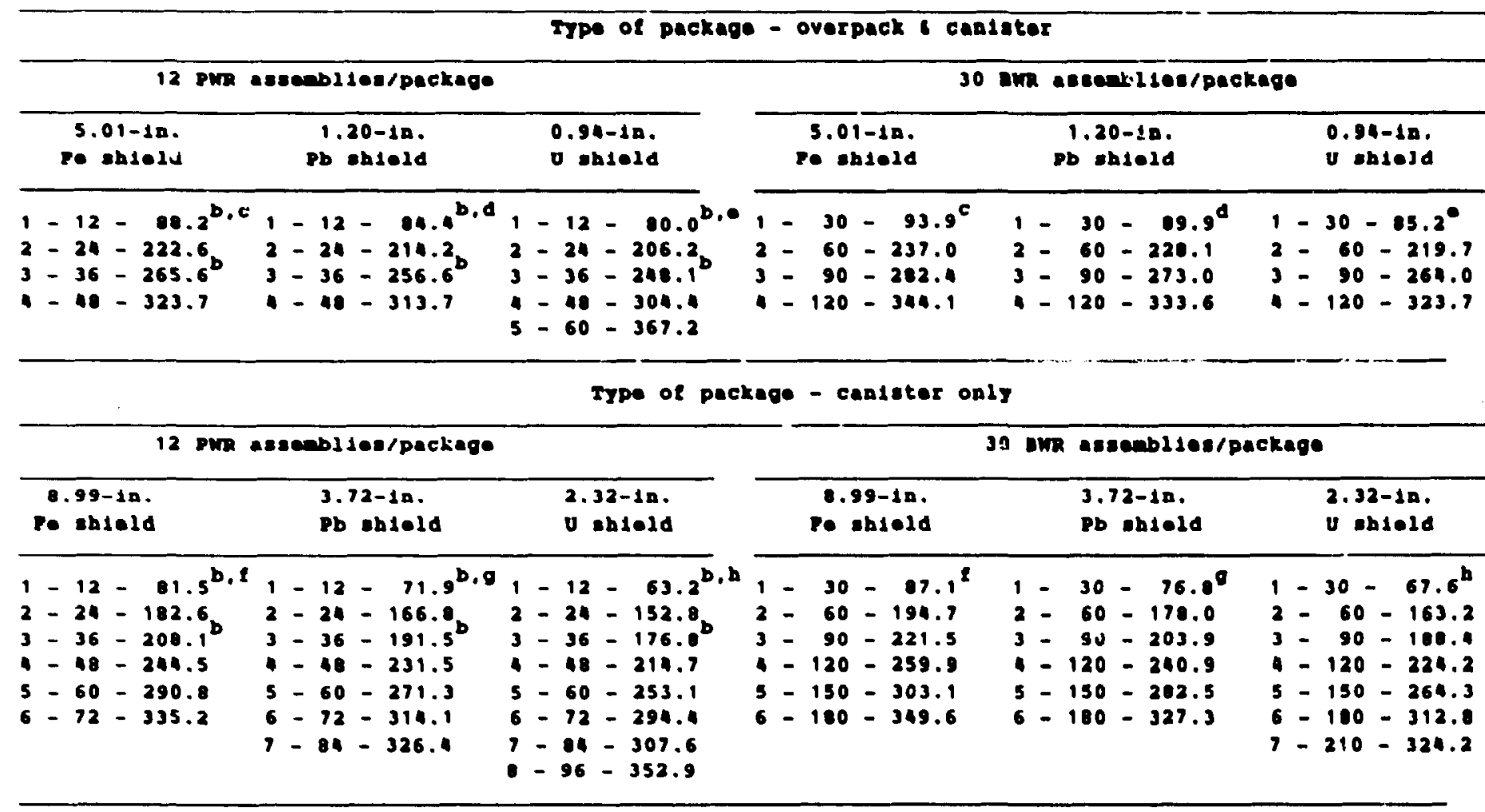

Tho a-e-mrv.v goreat used to present the date givess

a - the number of vaste packeges is the cask

- - the equivelent number of consolidated fuel assemblies in the cerk

- - the loaded velobt of the cask, where $222.6=222.600$ lbs

bcalculated dose rate 10 et froe centerline val $9.8-10.2$ mil11ree/hr.

Excoption - $t_{y}=\$ .501 \mathrm{~d}$. of re.

dexcoption $-t_{y}=0.94 \mathrm{la}$. Of $\mathrm{pb}$.

Exception $-t_{y}=0.79 \mathrm{ln}$. of $U$.

Exception - $t_{y}=8.10 \mathrm{1n}$. OL Jo.

Excoption - $t_{y}=3.37 \mathrm{1a}$. of Pb.

bexception $-t_{y}=2.11 \mathrm{la}$. of $\mathrm{u}$. 
Table 8. Groes weight of Tuff repository casks vs the number of waste packagesa

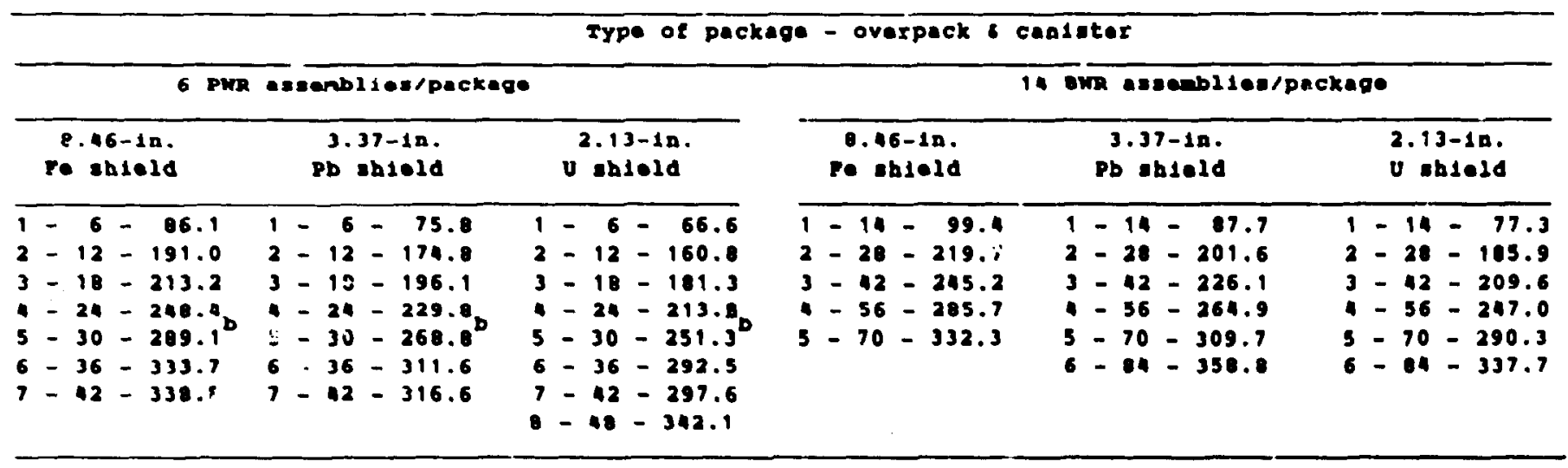

Type of packnge - canleter saly

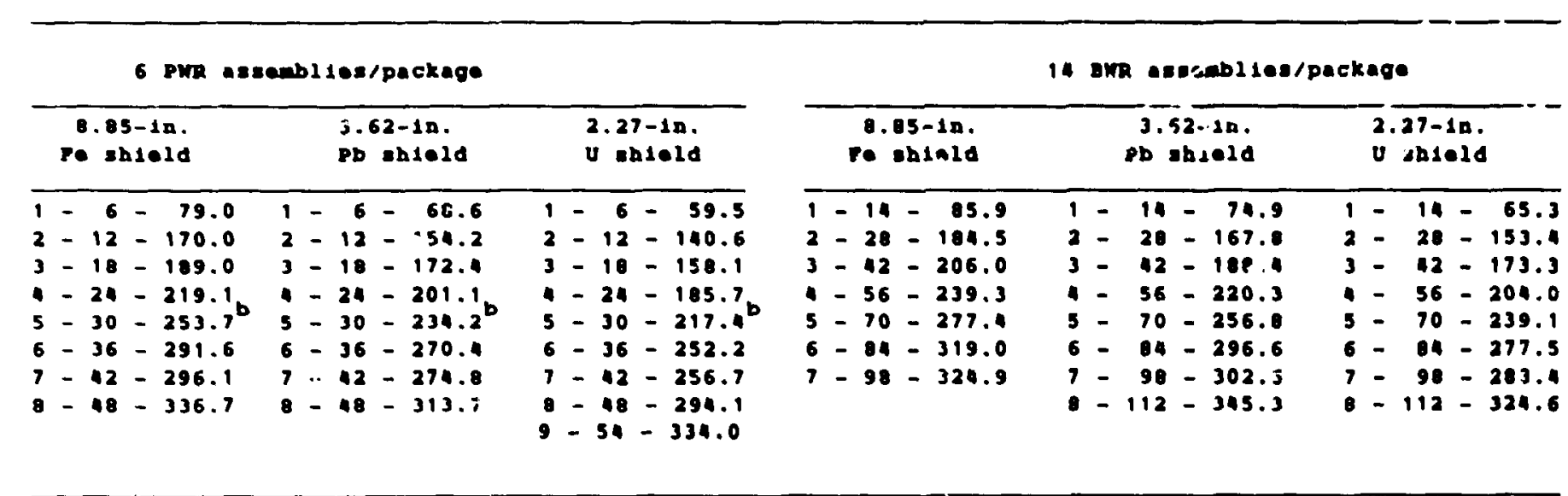

ate a-m-wwy. forat used to present the date gives:

a - the number of raste packegas in the cask.

- the equivelent aubier of consolideted fuel assemblies in the cask, and

$\checkmark$ - the londed velght of the cask. where $191.0=191,00018 \mathrm{~s}$.

celculeted dose rate 10 ft fran centerline was 9.8-10.2 m1ll1res/ar. 
Table 9. Orone weight of Basall roponitory caske ve the number of watte packagea

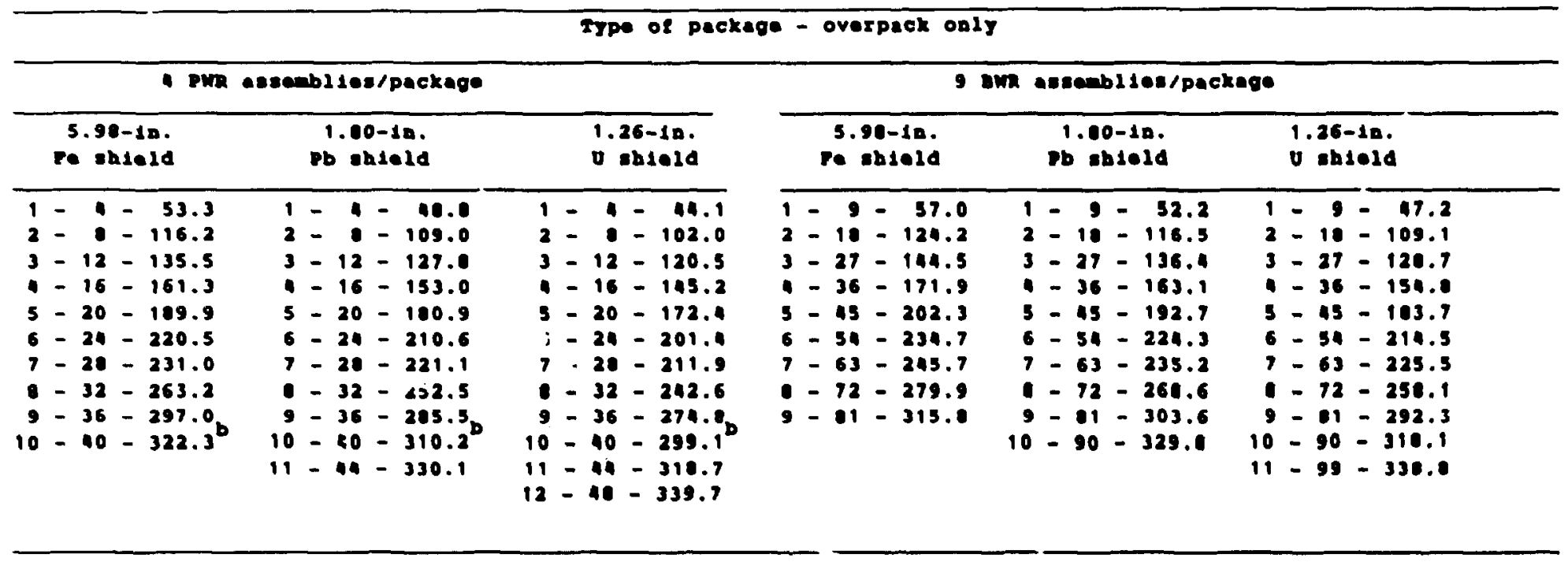


Table 9 (continued)

Type of peckege - canlster only

\begin{tabular}{|c|c|c|c|c|c|c|c|c|c|c|c|c|c|c|c|c|c|c|c|}
\hline \multicolumn{11}{|c|}{1 PWR Assambly/package } & \multicolumn{9}{|c|}{$2 \sin$ assembl 1en/package } \\
\hline \multicolumn{3}{|c|}{$\begin{array}{l}9.39-10 . \\
\text { ro sniald }\end{array}$} & \multicolumn{4}{|c|}{$\begin{array}{l}4.02-10 . \\
P b=a 101 d\end{array}$} & \multicolumn{4}{|c|}{$\begin{array}{l}2.52-12 . \\
\text { v }=b 101 d\end{array}$} & \multicolumn{3}{|c|}{$\begin{array}{l}9.39-12 . \\
\text { Fo } \cos 102 d\end{array}$} & \multicolumn{3}{|c|}{$\begin{array}{l}4.02-1 \mathrm{a} \text {. } \\
\mathrm{pb}=\mathrm{a} 1 \mathrm{e} d \mathrm{~d}\end{array}$} & \multicolumn{3}{|c|}{$\begin{array}{l}2.52-1 n \\
v-h 101 d\end{array}$} \\
\hline 27 & -27 & --186.2 & 32 & - & 32 & -190.1 & 35 & $-3:$ & $5-$ & -187.2 & 24 & 48 & -105.9 & 28 & 56 & -185.9 & 32 & 64 & -187.7 \\
\hline 28 & -28 & -189.9 & 33 & - & 33 & -195.4 & 35 & -30 & $6-$ & -192.2 & 25 & -50 & -189.7 & 29 & se & -190.3 & 33 & 66 & -193.2 \\
\hline 29 & -29 & -194.2 & 34 & - & 34 & -198.2 & 37 & -37 & $7-$ & -193.2 & 26 & $-\quad 32$ & -194.2 & 30 & 60 & -193.0 & 34 & -68 & -196.0 \\
\hline 30 & -30 & -196.9 & 35 & - & 35 & -202.2 & 38 & -30 & - - & -196.5 & 27 & -54 & -198.7 & 31 & -62 & $=194.1$ & 35 & -70 & -200.1 \\
\hline 31 & -31 & -197.9 & 36 & - & 36 & -207.3 & 39 & -38 & $9-$ & -200.1 & 28 & -36 & -202.7 & 32 & -64 & -203.0 & 36 & $-\quad 72$ & -205.4 \\
\hline 32 & -32 & -206.7 & 37 & - & 37 & -208.4 & 40 & -48 & $0-$ & -205.2 & 29 & -30 & -207.3 & 33 & -66 & -208.7 & 37 & $=74$ & -206.5 \\
\hline 33 & -33 & -212.3 & 38 & - & 38 & -211.8 & 41 & -4 & $1-$ & -208.5 & 30 & -60 & -210.1 & 34 & -68 & -211.6 & 38 & 76 & -210.0 \\
\hline 34 & -34 & -215.1 & 39 & - & 39 & -215.0 & 42 & -12 & $2-$ & -214.7 & 31 & 62 & -211.2 & 35 & 70 & -215.8 & 39 & 78 & -214.1 \\
\hline 35 & -35 & -219.2 & 10 & - & 40 & -220.7 & 43 & -13 & $3-$ & -221.1 & 32 & -64 & -320.5 & 36 & -72 & -221.3 & 10 & - $\quad 00$ & -219.2 \\
\hline • & & & $\cdot$ & & & & $\cdot$ & & & & $\cdot$ & & & $\cdot$ & & & 41 & $-\quad 12$ & -222.7 \\
\hline - & & & $\cdot$ & & & & $\cdot$ & & & & $\cdot$ & & & - & & & $\cdot$ & & \\
\hline$\cdot$ & & & $\cdot$ & & & & - & & & & $\cdot$ & & & - & & & - & & \\
\hline$\therefore$ & & & $\therefore$ & & & & $\dot{s}$ & & & & . & & & & & & & & \\
\hline 50 & -50 & -275.9 & 55 & - & 55 & -269.0 & 62 & -63 & $2-$ & -207.3 & 46 & 92 & -278.2 & 54 & -100 & -200.0 & 55 & -110 & -264.2 \\
\hline 51 & -51 & -279.6 & 56 & - & 56 & -290.8 & 63 & -63 & $3=$ & -280.3 & 47 & 94 & -283.2 & 55 & -110 & -281.9 & 56 & -112 & -205.4 \\
\hline 52 & -52 & -200.7 & 57 & - & 57 & -296.2 & 64 & -64 & - & -292.7 & 10 & 96 & -287.1 & 56 & -112 & -304.1 & 37 & -114 & -290.8 \\
\hline 53 & -53 & -281.7 & 58 & - & 58 & -297.2 & 65 & -68 & $5-$ & -295.9 & 43 & -98 & -289.3 & 57 & -114 & -309.7 & 58 & -116 & -292.0 \\
\hline 54 & -54 & $-280.0^{b}$ & 59 & - & 59 & $-298.3 b$ & 66 & -60 & $6-$ & $-299.5^{b}$ & 50 & -100 & -294.0 & se & -116 & -310.0 & 60 & -120 & -294.2 \\
\hline 55 & -55 & -289.1 & 60 & - & 60 & -299.3 & 67 & -67 & $7-$ & -300.6 & 51 & -102 & -298.0 & 59 & -110 & -311.9 & 61 & -122 & -297.4 \\
\hline 56 & -56 & -305.6 & 61 & - & 61 & -302.5 & 68 & -60 & - & -301.6 & 52 & -104 & - 299.0 & 60 & -120 & -313.0 & 62 & -124 & -301.4 \\
\hline 57 & -57 & -316.7 & 62 & - & 62 & -306.4 & 69 & -69 & 9 - & -307.7 & 53 & -106 & -300.1 & 61 & -122 & -316.3 & 63 & -126 & -302.5 \\
\hline 58 & -58 & -317.7 & 63 & - & 63 & -307.5 & 70 & -70 & 10 & -313.3 & 54 & -108 & -301.2 & 62 & -124 & -320.5 & 64 & -124 & -307.2 \\
\hline 59 & -59 & -318.8 & 64 & - & 64 & -312.0 & 71 & -7 & $11-$ & $-310 !$ & 55 & -110 & -302.3 & 63 & -126 & -321.5 & 65 & -130 & -310.5 \\
\hline 60 & -60 & -319.8 & 65 & - & 65 & -315.3 & 12 & -78 & 2 & -319.1 & 56 & -112 & -325.5 & 64 & -128 & -326.4 & 66 & -132 & -314.3 \\
\hline 61 & -61 & -323.1 & 66 & - & 66 & -319.1 & 13 & -72 & 3 & -320.2 & & & & & & & 68 & -136 & -316.5 \\
\hline 62 & -62 & -327.2 & 67 & - & 67 & -320.1 & 74 & -7 & & -327.1 & & & & & & & $\begin{array}{l}69 \\
70\end{array}$ & $\begin{array}{l}-138 \\
-140\end{array}$ & $\begin{array}{l}-317.6 \\
-328.9\end{array}$ \\
\hline
\end{tabular}


Table 9. (contiaued)

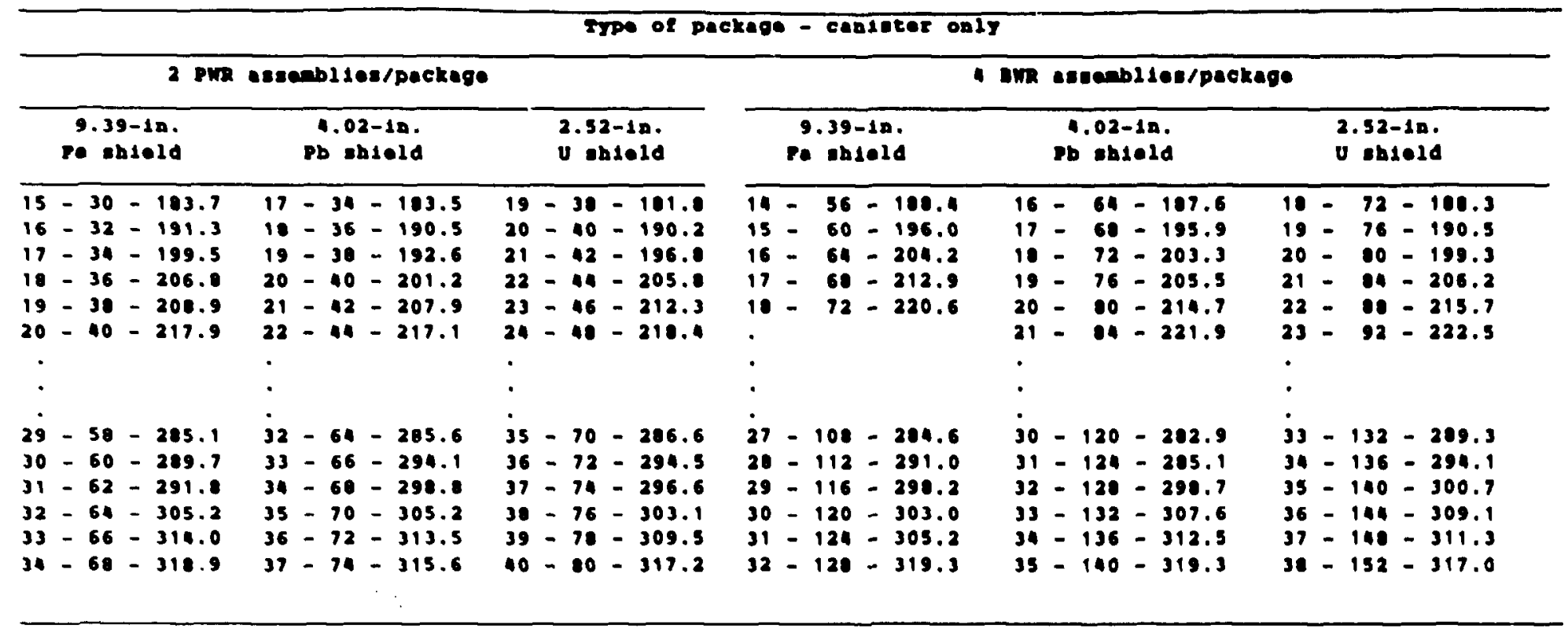

Iype of package - candeter only

\begin{tabular}{|c|c|c|c|c|c|c|c|c|c|c|c|c|c|c|c|c|c|c|}
\hline \multicolumn{10}{|c|}{3 PWR asacabl les/packege } & \multicolumn{9}{|c|}{7 INR aceatblles/package } \\
\hline & \multicolumn{2}{|c|}{$\begin{array}{l}9.39-1 \mathrm{a} \\
\text { Fo }=\mathrm{a} 102 \mathrm{~d}\end{array}$} & \multicolumn{4}{|c|}{$\begin{array}{l}1.02-1 \mathrm{~d} \text {, } \\
\text { pb } a b 102 d\end{array}$} & \multicolumn{3}{|c|}{$\begin{array}{l}2.32-10 \text {. } \\
v \text { obield }\end{array}$} & \multicolumn{3}{|c|}{$\begin{array}{l}9.39-12 \text {, } \\
\text { Te obiesa }\end{array}$} & \multicolumn{3}{|c|}{$\begin{array}{l}4.02-1 \mathrm{a} \text {. } \\
\text { po obdede }\end{array}$} & \multicolumn{3}{|c|}{$\begin{array}{l}2.32-1 a \text {. } \\
0 \text { obiese }\end{array}$} \\
\hline 10 & -30 & -184.8 & 12 & - & 36 & -186.3 & 13 & -39 & -186.4 & 9 & -63 & -185.3 & 11 & - & -189.3 & 12 & 84 & $1-184.0$ \\
\hline 11 & -33 & -193.3 & 13 & - & 39 & -197.3 & 14 & -12 & $=197.0$ & 10 & -70 & -197.3 & 12 & -8 & -198.9 & 13 & 91 & -195.3 \\
\hline 12 & -36 & -202.5 & 14 & - & 42 & -208.2 & 15 & -45 & -206.2 & 11 & -77 & -206.2 & 13 & -91 & -210.6 & 14 & -98 & -206.4 \\
\hline 13 & -39 & -213.9 & 15 & - & 45 & -217.6 & 16 & -40 & -216.1 & 12 & -84 & -216.0 & 14 & - & -222.1 & 15 & -105 & -216.1 \\
\hline & & $\cdot$ & & & & - & & & $\cdot$ & & & $\cdot$ & & & $\cdot$ & & & \\
\hline & & $\cdot$ & & & & $\cdot$ & & & $\cdot$ & & & • & & & - & & 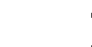 & • \\
\hline 20 & -60 & -287.2 & 22 & - & 66 & -290.4 & 24 & -72 & $\therefore-289.5$ & 19 & -133 & - 287.3 & 21 & -107 & -290.2 & & -134 & i -285.4 \\
\hline 21 & -63 & - 296.9 & 23 & - & 69 & - 299.7 & 25 & -15 & $3-290.2$ & 20 & -140 & -300.3 & 22 & -134 & $-3 n 3.6$ & 23 & -161 & -299.7 \\
\hline 22 & -66 & -310.2 & 21 & - & 72 & -308.4 & 26 & -10 & -306.9 & 21 & -147 & -310.6 & 23 & -161 & -.13 .3 & 24 & -168 & -300.7 \\
\hline 23 & - s9 & -319.0 & 25 & - & 75 & -316.2 & 27 & -11 & $1-313.9$ & 22 & -154 & -324.5 & 24 & -168 & -322.5 & 25 & -175 & -316.0 \\
\hline
\end{tabular}


Table 9 (continued)

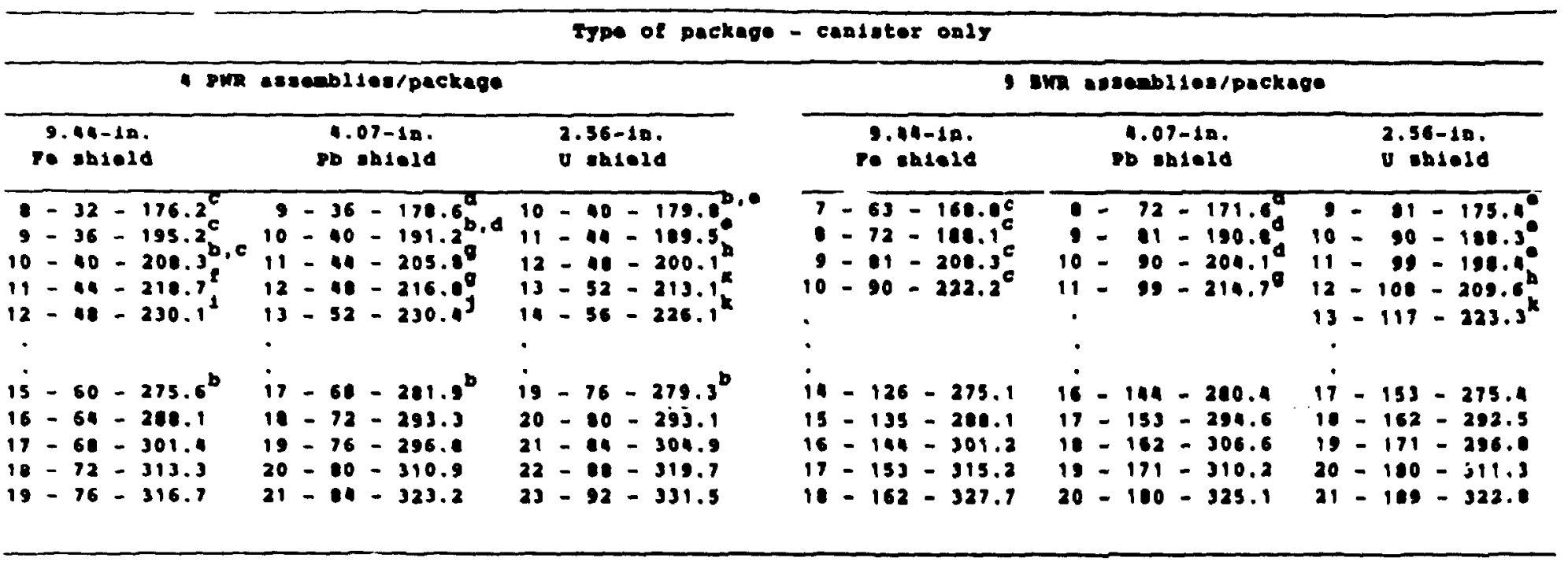

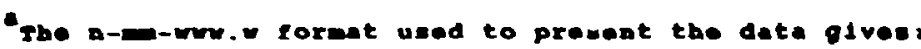

a - the aumber of veste packages in the cack.

- the equivalent nubber of consolsdated fuel asecablies in the cank, and

- - the loaded velght of the cask, were 193.2 = 193,200 lba.

belculated dose rate 10 tt eroe centerline was $9.1-10.2$ mld11rea/hr.

cexception - ty $=9.24 \mathrm{ln}$. of $\mathrm{pe}$.

$a_{\text {Excoption }}-t_{Y}=3.08 \mathrm{ip}$. of $\mathrm{pb}$.

Exception - ty = $2.41 \mathrm{la}$. ol v.

Exception - $t_{y}=9.28 \mathrm{la}$. of Po.

Exception - ty $=3.92$ 12. OR pb.

becoption - ty = 2.44 1a. of u.

Iexception $-t_{Y}=9.321 \mathrm{~A}$. of Pe.

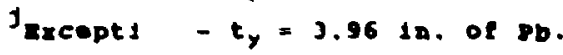

Excoption $-t_{y}=2.08$ in. of $u$. 
SCOPE output corresponding to each of these 522 individual cases. For each case, they give the actual neutron and gamma shield thicknesses; the gross loaded weight of the cask; the overall inside and outside dimensions of the cask (including external circumferential fins, when required); the steady-state temperature distribution; and the maximum transient temperature in certain key components during and after the postulated 30-min. fire.

Most (90-95\%) of the casts surveyed do not require external cooling fins. Some, however, do require 2-in-high circumferential fins in order to maintain an external surface temperature of $250^{\circ} \mathrm{F}$, given an outside ambient temperature of $130^{\circ} \mathrm{F}$. The worst case of practical interest corresponds to the large U-shielded cask for the Basalt repository which contains 84 PWR fuel assemblies in 21 thin-walled steel canisters. In this case, 4-in.-high $\times 0.25$-in.-thick stainless-steel fins were required every 4 in. along the outer surface of the cask. (The internal decay heat load associated with the 10-year-cooled spent fuel was 524 watts per PWR fuel assembly, and 168 watts per BWR fuel assembly.) In no case does the external diameter of a cask exceed 120 in., including the cooling fins.

Except for the steady-state and transient fuel $f$ in temperatures, the other calculated temperatures shown in the Appendix are considered fairly accurate. To calculate the maximum fuel pin cladding temperatures, the SCOPE code' assumes the fuel pins are dispersed within the canister or overpack in a square array. It then calculates the maximum fuel pin cladding temperature using the Wooton-Epstein correlation in which the primary mode of heat transfer is thermal radiation, with a small correction for thermal convection within the fuel bundle. For tightl-' compacted spent fuel (and for canisters with radial conductors, as in the Salt waste canister), the Wooton-Epstein equation will yield a very conservative result, such that the calculated temperatures are well above those that one would realistically expect. Even so, the calculated steady-state fuel pin clad temperatures are generally well below the point at which oxidation of the fuel becomes a significant problem. In those few cases where the calculated temperatures do approach this limit, a more rigorous thermal analysis may show the actual temperatures to be well below the limit. One obvious exception to this is the large U-shielded cask for the Basalt repository which contains 84 PWR fuel aseemblies in 21 thin-walled steel canisters. In this case, the steady-state temperature on the innermost portion of the removable aluminum insert may approach $500^{\circ} \mathrm{F}\left(260^{\circ} \mathrm{C}\right)$. While the maximum fuel pin temperature will be substantially less than the $718^{\circ} \mathrm{F}\left(381^{\circ} \mathrm{C}\right)$ shown in Table A.17, it will obviously be greater than that of the surrounding insert $\left(500^{\circ} \mathrm{F}\right.$ or $\left.260^{\circ} \mathrm{C}\right)$. In such cases it may be desirable to provide an inert atmosphere within the canister to prevent excessive oxidation of the fuel.

The detailed SCOPE output in the Appendix indicates that a few of the larger Pb casks containing more than $70 \mathrm{PWR}$ fuel assemblies may experience some melting of the $\mathrm{Pb}$ gamma shield during or after the hypothetical fire $\left(T_{\text {meth }}^{P_{6}}=620^{\circ} \mathrm{F}\right)$. However, several points should be noted: (a) Because of the lower decay heat loads, none of the casks containing BWR spent fuel experienced any melting of the $\mathrm{Pb}$ shield. (b) Of the several Pb-shielded PWR casks in the Appendix which exhibit some melting of the gamma shield, most weigh in excess of 300,000 lbs; and only one actually appears in Table 5 (that is, the Pb cask containing 76 PWR assemblies iti! 9 thin-walled canisters designed for the Basalt repository]. (c) The accident scenario used in the SCOPE code is unusually conservative insofar as it asqumes that the cask is allowed to attain a new (elevared) state of thermal equilibrium after the loss of the neutron shield and prior to the start of the 30-min. fire. In a more conventional scenario, one typically assumes that the 30 -min. fire begins concurrently with the loss of the neutren shield. Under the more conventional scenario, the gamma shield temperature at the start of the transient would be much lower; and it is doubtful that any significant melting would occur during or after the 30 -min. fire. While more detailed transient thermal analysea of the high-capacity $\mathrm{Pb}$ casks should be performed as the final mechanical designs evolve, the development of such casks should not be aborted prematurely based on the preliminary transient thermal analyses reported here. 
Shipping large numbers of consolidated fuel assemblies in a single large cask raises some interesting possibilities. Such systems must, however, be examined with respect to criticality safety. The highest capacity cask reported in this study is a $300,000-1 b$ U-shielded cask containing 84 consolidated PWR fuel assemblies in 21 thin-walled steel canisters designed for the Basalt repository. As noted below, a slightly more reactive variation of this particular cask has been analyzed and found to have a generation-to-generation neutron multiplication factor $\left(k_{e n}\right)$ no greater than $0.536 \pm 0.002$, even if one assumes that the PWR fuel is unirradiated and contains $3.4 w t \%$ U-235. The low neutron mul:iplication factor in these highly specialized casks stems from several factors: (a) the consolidated fiel pins have a small pitch-to-diameter ratio, (b) the fuel is shipped dry in canisters that are hermetically sealed at the MRS facility, and (c) the solid aluminum insert between the canisters effectively displaces any interstitial water that might be in the cask during loading (or in the event of a transportation accident). While the other lower-capacity casks reported in this study should eventually be analyzed in a similar fashion, it would appear, based on this preliminary evaluation, that all of the other casks would also be safely subcritical.

The criticality safety analysis referenced above was performed using Criticality Safety Analysis Sequence no. 2 (CSAS2) as incorporated in the NRC-sponsored SCALE system for Standardized Computir Analyses for Licensing Evaluation. ${ }^{47}$ That particular analytical sequence employs the NITAWL resonance self-shielding code, ${ }^{8}$ the XSDRNPM discrete ordinates transport code ${ }^{2}$ for cell-averaging the multigroup cross sections, and the KENO IV Monte Carlo criticality program. ${ }^{6}$ The SCALE system's 27-group ENDF-IV cross-section library was also used. The analysis assumes that 816 unirradiated zircalloy-clad PWR fuel pins from four Westinghouse $15 \times 15$ fuel assemblies* are placed in a thin-walled carbon steel canister having an inside diameter of $32 \mathrm{~cm}$ and an outside diameter of $33 \mathrm{~cm}$. The fuel pins contain $3.4 \mathrm{wt} \% \mathrm{U}-235$, and have an outside rod diameter of $1.0719 \mathrm{~cm}$; a clad thickness of $0.0617 \mathrm{~cm}$; a fuel pellet diameter of $0.9294 \mathrm{~cm}$; and a $\mathrm{UO}_{2}$ density of $10.4 \mathrm{I} / \mathrm{cc}$. Within the given canister, the compacted fuel pins were assumed to be spaced on a close-packed triangular pitch of $1.2318 \mathrm{~cm}$. [The $10560.95-\mathrm{cm}$-diam. fuel rods from four of the newer Westinghouse $17 \times 17$ assemblies would yield a slightly tighter lattice pitch, but would contain essentially the same amount of $\mathrm{UO}_{2}$ per canister and have approximately the same $k_{\text {enf }}$ as long as the canister is dry.] For an infinite lattire of such fuel pins, the one-dimensional XSDRNPM code yielded a $k_{\text {erl }}$ of 0.6797 . A simplified KENO IV model was then created which accounts for interstitial moderation by the aluminum insert and reflection by the inner walls of the cask (see Fig. 7). An homogenized mixture representing the unirradiated fuel pins was placed inside a 0.45 -cm-thick carbon steel canister whose outside dimensions measured $29.25 \mathrm{~cm} \times 29.25 \mathrm{~cm}$. (These dimensions preserve the amount of fuel and the amount of steel in the cylindrical canisters previously described.) The steel canister was then surrounded by a 1.27 -cm-thick aluminum canister whose outside dimensions measured $31.79 \mathrm{~cm} \times 31.79 \mathrm{~cm}$. Twenty-five of these composite canisters were arranged in a tight-fitting $5 \times 5$ array which was surrounded on four sides by materials representing the inner walls of the U-shielded cask-that is, $1.905 \mathrm{~cm}$ of stainless steel, $6.5024 \mathrm{~cm}$ of depleted uranium metal, and anothes $5.08 \mathrm{~cm}$ of stainless steel. Mirror-like boundary conditions were applied to the two axial ends of the madel, resulting in the conservative 2-D representation depicted in Fig. 7. Subsequent KENO IV analysis of this (dry) system showed it to be safely subcritical, with a $k_{\text {err }}$ of $0.536 \pm 0.002$.

"Each assembly contains 204 fuel pins and 21 guide tubes to accommodate the movable control rod cli sters. 
ORNL-OWG E-18137A

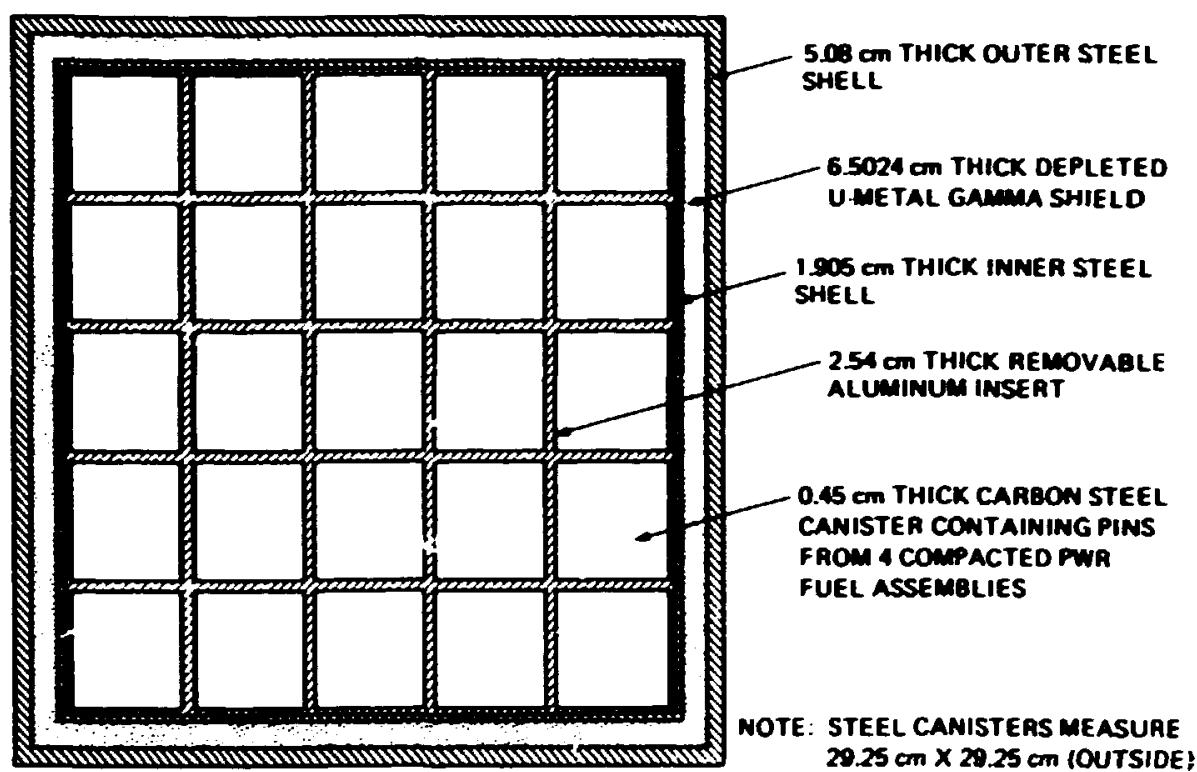

Fig. 7. A simplified 2-D KENO IV model of a large U-shielded cask containing 100 consolidated PWR fuel assemblies in 25 thin-walled steel canisters. 


\section{CONCLUSIONS}

The objective of this study was to determine the maximum nurr ber of repository waste packages twat could be shipped in PL-, Fe-, and U-shieldad casts having a groes loaded weight of 200,000 or 300,000 lbs. This determination was made for each of 18 different waste pactages defined by requirements at the Salt. Tuff, and Basalt repositories. The waste pactages were comprised $x$ thin-walled stecl canisters, thick-walled stoel overpacks, st overpacks containing a single canister. Depending on the particular repository and the particular design, each waste package contained 1-12 consolidated PWR fuel assemblies or 2-30 consolidatod BWR fuel assemblies (see Sect. 2).

Subsequent to the initial scoping analysis but prior to the final scoping analysis, discrete ordinates shielding cakculations were performed for 30 cases of potential interest. The object of these calculations was to determine the actual neutron and gamma shield thicknesses that would yield a dose rate of 10 millirem/hr at a point $10 \mathrm{ft}$ from the centerline of the cask, assuming that the consolidated PWR fuel had been irradiated to 33,000 MWd/MTIHM and allowed to cool for 10 years. While sonewhat conservative, these same neutron and gamma shield thicknesses were also assumed to apply to casts containing consolidated BWR fuel irradiated to 27,500 MWd/MTIHM.

Tables 5 and 6 show the number of consolidated PWR and BWR fuel assemblies that may be shipped in 200,000-1b and 300,000-lb Pb-, Fe-, and U-shielded casks designed to accommodate the 18 repository waste packages previously described. The 108 particular cask designs associated with these limits are a subset of a larger group of 522 potentially interesting cask designs for which more detailed information is also given. This information includes the gross weight of the casks as a function of the number of waste packages or consolidated fuel assemilies, the overall cask dimensions, the actual neutron and gamma shield thicknesses, the internal temperature distribution under nominal steady-state conditions, and the maximum temperature in key components during and after a 30-min. fire. In general it should be noted that:

(a) Relative to the 200,000-1b casks, 50-100\% more fuel may be shipped in the larger 300,000-1b casks.

(b) Placing the spent fuel canisters in overpacks prior to shipment from the MRS will reduce the net payload by about 30-50\%.

(c) For a given payload, the U-shielded cask will weigh less than a Pb-shielded cask, which will weigh less than an Feshielded cask.

(d) For the high capacity waste packages used at the Salt and Tuff repositories, the Pb-and U-shiclded casks will offer equal payload capacities, with the only tangible difference being the overall weight. For the smaller waste packages used at the Bacalt repository, the U. shielded casks do of fer a noticeable payload advantage.

(c) Most (i.e., 90-95\%) of the casks surveyed do not require external cooling fins. Some of the higher-capacity casks, however, may require 2- to 4-in.-high circumferential cooling fins. In no case does the external diarreter of a cask exceed 120 in., including cooling fins.

(f) Use of some of the higher-capa ity casks may require that the thin-walled canisters be filled with an inert atmosphere if excessive oxidation of the fuel is to be avoided.

(g) The highest capacity cask/waste package combination studied corresponds to a $300,000-\mathrm{lb}$ U-shielded cask containıng 84 consolidated PWR fuel assemblies in 21 thin-walled steel canisters, or 171 consolidated BWR fuel assemblies in 19 thin-walled steel canisters. Preliminary KENO IV criticality analyses have shown these high-capacity casks to be safely subcritical-even if all of the canisters were loaded with unirradiated PWR fuel pins containing 3.4 wt\% U-235. 


$$
27 / 23
$$

Based on these findings, one may conctude that the total number of required shipments between the MRS and the various repositories may be substantially reduced through the use of larger casks especially designed for the various repocitory waste packagea. 


\section{$29 / 3 c$}

\section{REFERENCES}

1. J. A. Bucholz, Scoping Design Analy.es for Optimized Shipping Casks Comeining I-, 2-, 3-, 5-. 7-, or 10-Year-Old PWR Sper: Fuel, ORNL/CSD/TM-149, Martin Marietta Energy Systems, Inc., Oak Ridge Nat. Lab., January 1983.

2. N. M. Greene and L. M. Petrie, XSDRNPM-S: A One-Dimensional Discrete Ordinates Code for Transport Analysis," Section F3 of SCALE: A Modular Code System for Performing Standardized Computer Aralyses for Licensing Evaluation, NUREG/CR-0200, Vol. 2. Rev. 2, U.S. Nuctear Regulatory Commission, June 1983.

3. J. A. Bucholz, XSDOSE: A Module for Calculating Fluxes and Dose Rates at Points Outside a Shield, Section F4 of SCALE: A Modular Code System for Performing Standardized Computer Analyses for Licensing Evaluation, NUREG/CR-0200, Vol. 2, Rev. 2, U.S. Neclear Regulatory Commission, June 1983.

4. Staff of Technical Applications, Computing and Telecommunications Division at ORNL, SCALE: A Modular Code System for Performing Standardized Computer Analyses for Licensing Evaluation, NUREG/CR-0200, Vols 1-3, U.S. Nuclear Regulatory Commission (originally issued July 1980, reissued January 1982, Revision 1 iscued July 1982, Revision 2 issued June 1983, Revision 3 issued December 1984), .

5. J. R. Knight, C. V. Parks, L. M. Petrie, SASI: A One-Dimensional Shielding Analysis Module," Section S1 of SCALE: A Modular Code System for Performing Standardized Computer Analyses for Licensing Evaluation, NUREG/CR-0200, Vol. 1 (to be published by U.S. Nuclear Regulatory Commission).

6. L. M. Petrie and N. F. Landers, KENO IV/S - An Improved Monte Carlo Criticality Program," Section FS of SCALE: A Modular Code System for Perfo:ming Standardized Computer Analyses for Licensing Evaluation, NUREG/CR-0200, Vol. 2, U.S. Nuclea: Keguia'ory Commissinn, January 1982.

7. J. A. Bucholz, "CSAS2: A Multidimensional Criticality Safety Analysis Module," Section C2 of SCALE: A Modular Code System for Performing Standardized Computer Analyses for Licensing Evaluation, NUREG/CR-0200, Vol. 1, U.S. Nuclear Regulatory Commission, January 1982.

8. R. M. Westfall et al., NITAWL-S: SCALE System Module for Performing Resonance Shielding and Working Library Production," Section F2 of SCALE: A Modular Code Sysiem for Performing Standardized Computer Analyses for Licensing Evaluation, NUREG/CR-0200, Vol. 2, U.S. Nuclear Regulatory Commission, Januai; 1982. 


\section{APPENDIX}

Tables A.1-A.18 show the actual SCOPE output for all of the cases summarized in Sect. 5. For each cask/waste package configuration, they give the actual neutron and gamma shield thicknesses, the gross baded weight of the cask, the overall inside and outside dimensions of the cask (including external cooling fins, when required), the steady-state temperature distribution, and the maximum transient temperature in certain key components during and after the postulated 30-min. Fire. This information is tabulated for each type of cask 2, a function of the number of waste packages (i.e., canisters) in the cask. The 18 tables in th is Appendix may be briefly described as follows:

Table A.1. Salt reference design; overpack and canister with 12 PWR assemblies/pactage Table A.2 Salt reference design; overpack and canister with 30 BWR assemblies/pactage Table A.3. Salt reference design; bare canister with 12 PWR assemblies/package Table A.4. Salt reference design; bare canister with 30 BWR assemblies/package Table A.5. Tuff reference design; overpack and canister with 6 PWR assemblies/package Table A.6. Tuff reference design; overpack and canister with 14 BWR assemblies/package Table A.7. Tuff reference design; bare canister with 6 PWR assemblies/package Table A.8. Tuff reference design; bare canister with 14 BWR assemblies/package Table A.9. Basalt reference design; overpack only, with 4 PWR assemblies/package Table A.10. Basalt reference design; overpack only, with 9 BWR assemblies/package Table A.11. Basalt reference design; canister only, with 1 PWR assembly/package Table A.12 Basalt reference design; canister only, with 2 BWR assemblies/package Table A.13. Basalt reference design; canister only, with 2 PWR assemblies/package Table A.14. Basalt reference design; canister only, with 4 BWR assemblies/package Table A.15. Basalt reference design; canister only, with 3 PWR assemblies/package Table A.16. Basait reference design; canister only, with 7 BWR assemblies/package Table A.17. Basalt reference design; canister only, with 4 PWR assemblies/package Table A. 18. Basalt reference design; canister only, with 9 BWR assemblies/package 


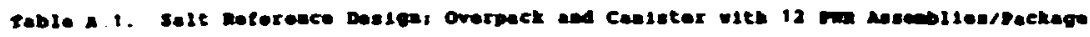

\begin{tabular}{|c|c|c|c|c|c|c|c|c|c|c|c|c|c|c|c|c|c|c|c|}
\hline \multirow[b]{2}{*}{$\cos$} & \multirow[b]{2}{*}{ Cows. } & \multicolumn{3}{|c|}{ wringuks } & \multicolumn{2}{|c|}{$\begin{array}{l}\text { mexcoses } \\
\text { In Incise }\end{array}$} & \multirow{2}{*}{$\begin{array}{l}\text { car } \\
\text { aser } \\
\text { iturs }\end{array}$} & \multirow{2}{*}{ ID } & \multicolumn{3}{|c|}{$\begin{array}{l}\text { DI wistoss } \\
\text { If Incins }\end{array}$} & \multirow{2}{*}{ in. } & \multicolumn{4}{|c|}{ 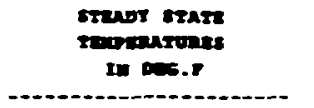 } & \multicolumn{3}{|c|}{ 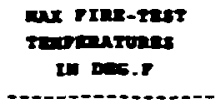 } \\
\hline & & new & $\begin{array}{l}\text { can. } \\
\text { sixo }\end{array}$ & סוחש & can. & Des & & & $\infty$ & 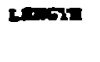 & $\begin{array}{l}\text { IIx } \\
\text { m. }\end{array}$ & & rif & $\begin{array}{l}\text { mext } \\
\text { wns }\end{array}$ & مس & $\begin{array}{l}\text { cast } \\
\text { saner. }\end{array}$ & $\begin{array}{l}\text { roux } \\
\text { pro }\end{array}$ & $\begin{array}{l}\text { Imter } \\
\text { axter }\end{array}$ & Com \\
\hline 10.0 & 1 & AL & mo & 1200 & 0.94 & 0.25 & 94.4 & 31.3 & 52.4 & 195.7 & $\bullet .0$ & $\bullet .0$ & 590 & 197 & 196 & 199 & ונט & 46 & 62 \\
\hline 10.0 & 2 & $\boldsymbol{M}$ & $\mathbf{s}$ & $=20$ & 1.26 & $=.25$ & 216.2 & 70.1 & 09.7 & 196.2 & $\bullet$ & $\bullet$ & 652 & 279 & 200 & 196 & 176 & 115 & 196 \\
\hline 16. & 3 & 4 & $\mathbf{w}$ & $=20$ & 1.20 & 4.25 & 256.6 & 75.6 & os - & 196.2 & $\bullet .0$ & $\bullet .0$ & 650 & 320 & 227 & 217 & .27 & 490 & 493 \\
\hline 14.0 & 4 & M & 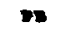 & 200 & 1.20 & 0.23 & 313.7 & 04.6 & 104.0 & 196.2 & 0.0 & 0.0 & 716 & 361 & 244 & 232 & as? & 332 & 522 \\
\hline 10.0 & I & $\mathbf{A L}$ & $n$ & 120 & 9.50 & 3.75 & 08.2 & 33.5 & 53.2 & 196.4 & $\bullet$. & 0.1 & 507 & 195 & 194 & 106 & ;90 & 121 & 121 \\
\hline 10.0 & 2 & $\boldsymbol{A}$ & $\boldsymbol{m}$ & 1020 & $5 . \bullet 1$ & 3.73 & 222.6 & 70.1 & 90. & 197.3 & $\bullet$ & $\bullet$ & 65 & 277 & 203 & 195 & 762 & 10 & 41 \\
\hline 10.0 & 3 & A & $\boldsymbol{n}$ & 1020 & 5.01 & 3.75 & 265.6 & 73.6 & 26.2 & 197.3 & $\bullet .0$ & $\bullet .0$ & 60 & 125 & 226 & 216 & 11 & 4es & 459 \\
\hline 10.0 & $\bullet$ & $\mathbf{A L}$ & $m$ & 200 & 5.01 & 3.75 & 323.7 & 04.6 & 105.1 & 137.3 & $\bullet . \bullet$ & $\bullet . \bullet$ & 113 & 330 & 202 & 230 & 899 & 321 & eอง \\
\hline 10.0 & ' & $\mathbf{A B}$ & - & 020 & 0.79 & 3.47 & $\bullet \bullet$ & 30.5 & 49.6 & 192.3 & $\bullet$ & $\bullet .0$ & 592 & 201 & 200 & 193 & ess & 493 & 492 \\
\hline 16.0 & 2 & $\mathbf{A s}$ & - & 20 & 0.94 & 3.01 & 286.2 & 70.3 & 06.1 & 192.6 & 0.0 & 0.0 & 654 & $2 \pm 1$ & 207 & 199 & 173 & 624 & 469 \\
\hline 16. & 3 & $\mathbf{a b}$ & $=$ & $=20$ & 0.94 & 3.47 & 246.1 & 13.6 & $91+3$ & 192.6 & 0. & $\bullet$ & 692 & 310 & 231 & 221 & 032 & 497 & 516 \\
\hline 10.6 & 4 & $\mathbf{x}$ & v & 120 & 1.94 & 3.47 & Jen. & 04.6 & 186.1 & 192.6 & 0 & 1.0 & 710 & 363 & 248 & 236 & ese & 530 & sas \\
\hline 10.0 & 5 & $\mathbf{a r}$ & $\boldsymbol{\nabla}$ & 120 & 0.94 & 3.47 & 367.2 & 90.5 & 110.3 & 192.6 & $\bullet .0$ & $\bullet . \bullet$ & 736 & 381 & 260 & 207 & 104 & sos & 366 \\
\hline
\end{tabular}

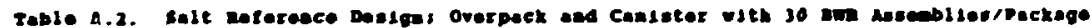

\begin{tabular}{|c|c|c|c|c|c|c|c|c|c|c|c|c|c|c|c|c|c|c|c|}
\hline \multirow[b]{2}{*}{$\begin{array}{l}\text { rutel } \\
\text { AGE }\end{array}$} & \multirow{2}{*}{ cans } & \multicolumn{3}{|c|}{ mrgirals } & \multicolumn{2}{|c|}{$\begin{array}{l}\text { Teicintes: } \\
\text { If tuctus }\end{array}$} & \multirow{2}{*}{$\begin{array}{l}\text { cust } \\
\text { witent } \\
\text { (xbes) }\end{array}$} & \multicolumn{5}{|c|}{$\begin{array}{l}\text { orwionstows } \\
\text { tw rective }\end{array}$} & \multicolumn{4}{|c|}{ 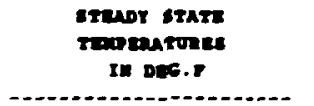 } & \multicolumn{3}{|c|}{ 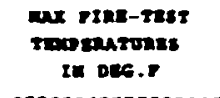 } \\
\hline & & Intm & eNt. & $\begin{array}{l}\text { max } \\
\text { stato }\end{array}$ & $\begin{array}{l}\text { can. } \\
\text { sano }\end{array}$ & witer & & ID & $o p$ & Letox & $\begin{array}{l}\text { ry } \\
\boldsymbol{m} .\end{array}$ & $\begin{array}{l}p 10 \\
\pi x .\end{array}$ & $\begin{array}{l}\text { wore } \\
\text { DIn }\end{array}$ & $\begin{array}{l}\text { Imem } \\
\text { warl }\end{array}$ & sento & $\begin{array}{l}\text { ceser } \\
\text { sone. }\end{array}$ & $\begin{array}{l}\text { rote } \\
\text { orw }\end{array}$ & $\begin{array}{l}\text { Imbar } \\
\text { mart }\end{array}$ & enco \\
\hline 10.0 & 1 & at & $\mathbf{D}$ & 120 & 0.94 & 0.25 & 9.9 & 13.5 & 52.0 & 209.5 & $0 . r$ & 0.0 & 500 & 103 & 182 & 176 & 732 & 433 & 132 \\
\hline 10.0 & 2 & At & $\mathbf{m}$ & $n 20$ & 1.20 & 0.25 & 220.1 & 10.3 & 09.7 & 210.0 & 0.0 & 0.0 & SS1 & 241 & 180 & 162 & 662 & 374 & 114 \\
\hline 10.0 & $\mathbf{3}$ & $\mu$ & m & 120 & 1.20 & 0.25 & 273.0 & 15.6 & 95.0 & $=10.0$ & 0.0 & 0.0 & $\operatorname{sen} 2$ & 206 & 207 & 199 & 711 & 136 & iss \\
\hline 10.0 & 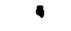 & $M L$ & $\boldsymbol{\theta}$ & 1120 & 1.20 & 4.25 & 333.6 & 00.6 & 100.0 & 210.0 & 0.0 & 0.0 & 604 & 313 & 220 & 211 & 139 & 47 & 100 \\
\hline 10.0 & 1 & $\boldsymbol{A L}$ & $n$ & $=20$ & 4.30 & 3.75 & 93.9 & 33.3 & 33.2 & 210.2 & 0.0 & 0.0 & 495 & 101 & 181 & 116 & csi & 392 & 391 \\
\hline 10.0 & 2 & AL & $n$ & $=20$ & 5.01 & 3.15 & 237.0 & 10.3 & 90.0 & 211.1 & 0.0 & 0.0 & ses & 243 & 107 & 102 & 654 & 366 & 378 \\
\hline 10.0 & $\mathfrak{3}$ & As & $\mathbf{m}$ & 930 & 5.01 & 3.75 & 202.4 & 75.6 & 96.2 & 211.1 & 0.0 & 0.0 & 300 & 203 & 206 & 190 & 702 & 126 & 120 \\
\hline 10.0 & $\bullet$ & $\mu$ & $m$ & $=20$ & 3.01 & 3.13 & 3010.1 & 10.6 & 105.1 & 211.1 & 0.0 & 0.0 & 602 & 310 & 218 & 210 & 730 & 161 & 196 \\
\hline 10.0 & 1 & al & $\mathbf{0}$ & 120 & 0.79 & 3.47 & 05.2 & 33.5 & 99.0 & 206.1 & 0.0 & 0.0 & 503 & 106 & 105 & 119 & 160 & 162 & 162 \\
\hline 10.0 & 2 & Ab & $\mathbf{v}$ & 1020 & 0.91 & 3.47 & 219.7 & 90.3 & 10.1 & 206.9 & 0.0 & 0.0 & S\$2 & 208 & 191 & 105 & 666 & 318 & 137 \\
\hline 10.0 & 3 & $A b$ & 0 & $m 20$ & 0.34 & 3.17 & 264.0 & 15.6 & 91.5 & 206.1 & 0.0 & 0.0 & 504 & 200 & 211 & 203 & 116 & 442 & 171 \\
\hline 10.0 & 1 & AL & 0 & 1120 & 0.10 & 3.17 & 123.7 & 04.6 & 100.4 & 206.4 & 0.0 & 0.0 & cos & 315 & 220 & 213 & 745 & 917 & 30; \\
\hline
\end{tabular}




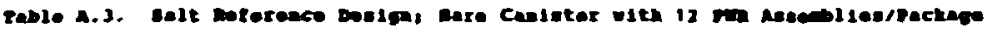

\begin{tabular}{|c|c|c|c|c|c|c|c|c|c|c|c|c|c|c|c|c|c|c|c|}
\hline \multirow[b]{2}{*}{ mat } & \multirow{2}{*}{ mis. } & \multicolumn{3}{|c|}{ mirerake } & \multicolumn{2}{|c|}{$\begin{array}{l}\text { michese } \\
\text { In xwewiss }\end{array}$} & \multirow{2}{*}{$\begin{array}{l}\text { cave } \\
\text { ineres } \\
\text { icuess }\end{array}$} & \multirow{2}{*}{ ro } & \multicolumn{4}{|c|}{ 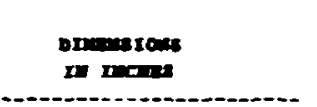 } & \multicolumn{4}{|c|}{ 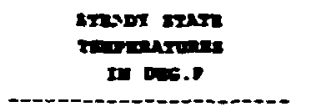 } & \multicolumn{3}{|c|}{ 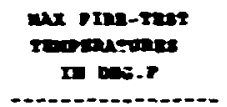 } \\
\hline & & nater & $\operatorname{con}$ & ind & ente. & סוس & & & $\infty$ & -1002 & rm. & Tx. & wine & $\begin{array}{l}\text { nwos } \\
\text { wex }\end{array}$ & סing & $\begin{array}{l}\text { cant } \\
\operatorname{coser} .\end{array}$ & intax & $\begin{array}{l}\ln x \\
\operatorname{mar}\end{array}$ & and \\
\hline 10.0 & 1 & $\mathbf{u l}$ & m & 120 & 3.37 & 4.25 & 11.9 & 20.7 & 40.1 & 102.2 & 0.0 & $\bullet$ & 641 & 209 & 207 & 196 & 164 & 165 & ec2 \\
\hline 19.6 & 2 & $\mathbf{a l}$ & $m$ & 120 & 3.72 & 1.25 & 166.8 & 92.6 & 77.0 & 102.9 & 0.0 & $\bullet . \bullet$ & 725 & 326 & 231 & 209 & 149 & 178 & 162 \\
\hline 10.4 & $\mathbf{3}$ & $n x$ & $\mathbf{n}$ & 120 & 3.72 & 0.25 & 191.5 & 36.5 & 01.0 & 102.9 & 0.0 & 6 & 711 & 389 & 251 & 230 & 913 & 562 & 317 \\
\hline 10.0 & $\bullet$ & $\mathbf{u}$ & $\mathbf{m}$ & 120 & 3.72 & 0.15 & 231.5 & 13.2 & 91.6 & te2.9 & 2.0 & -25 & 702 & 498 & 230 & 218 & 951 & 610 & 572 \\
\hline 10.0 & $s$ & at & $\mathbf{n}$ & 120 & 3.72 & $e .25$ & 271.3 & 70.6 & 99.0 & 162.9 & 2.0 & 0.25 & 003 & 132 & 251 & 229 & 974 & -602 & 596 \\
\hline 16. & 6 & as. & $m$ & man & 3.72 & 4.25 & 318.1 & 70.2 & 106.7 & 102.9 & 2.0 & 0.25 & 019 & ase & 261 & 237 & 909 & 668 & 614 \\
\hline 10.0 & 7 & $\mathbf{A}$ & $\boldsymbol{m}$ & 120 & 3.12 & 1.25 & 326.4 & 18.2 & 100.7 & 102.9 & 3.0 & e.25 & ors & 493 & 270 & 243 & 1040 & 127 & $6590^{\circ}$ \\
\hline 16. & 1 & $\mathbf{A L}$ & $\mathbf{n}$ & $=20$ & 6.40 & 3.75 & e1.s & 24.7 & 53.1 & 1es.s & $\bullet .0$ & $\bullet .0$ & 636 & 202 & 201 & 191 & 793 & 3eg & ces \\
\hline 10.0 & 2 & at & $n$ & $=20$ & 0.99 & 3.75 & 202.6 & 52.6 & 1.0 & 107.0 & $\bullet$ & $\bullet .0$ & 721 & 320 & 216 & 205 & 029 & 455 & 424 \\
\hline 10.0 & 3 & ax & $m$ & $=200$ & 0.99 & 3.75 & 200.1 & 36.5 & es.e & 187.0 & $\bullet .0$ & $\bullet$ & 766 & 381 & 208 & 229 & ses & s3s & 479 \\
\hline 10.0 & - & $\mathbf{a x}$ & $n$ & $=00$ & 0.99 & 3.75 & 244.5 & 63.2 & 91.7 & 107.0 & $\bullet$ & $\bullet .0$ & 796 & 922 & 265 & 246 & 927 & 506 & 515 \\
\hline 10.0 & 3 & at & $m$ & 120 & -.99 & 3.15 & 296.8 & 70.6 & 103.0 & 101.0 & 2.0 & 0.25 & 790 & 125 & 245 & 224 & 248 & 614 & 350 \\
\hline 10.3 & 6 & as & $m$ & 120 & 0.99 & 3.75 & J35.2 & 70.2 & 110.7 & 107.0 & 2.0 & 0.25 & 10 & 417 & $25 s$ & 232 & 967 & 639 & 373 \\
\hline 10.0 & 1 & as & $\mathbf{0}$ & 120 & 2.11 & 3.47 & 61.2 & 20.7 & 42.0 & 176.6 & $\bullet .0$ & 1.0 & 646 & 217 & 215 & 205 & ess & (9) & 490 \\
\hline 10.0 & 2 & at & 0 & $m 20$ & 2.32 & 3.47 & 152.0 & 52.6 & 71.1 & 171.1 & $\bullet$ & 0.0 & 129 & ונ3 & 220 & 216 & ese & 990 & 981 \\
\hline 10.0 & 3 & at & v & $=20$ & 2.32 & 3.67 & 176.0 & 56.5 & 75.1 & 177.1 & 0.0 & 0.0 & 775 & 398 & 259 & 203 & 923 & 534 & 303 \\
\hline 10.6 & - & $\mathbf{n}$ & 0 & $m 20$ & 2.32 & 3.67 & 214.7 & 63.2 & es.t & 137.1 & 2.0 & 0.25 & Tes & 007 & 24 & 223 & 960 & 621 & 601 \\
\hline 10.0 & 5 & at & 0 & $m 20$ & 2.32 & 3.67 & 253.1 & 70.6 & 93.1 & 171.1 & 2.0 & 0.23 & oes & ass & 257 & 236 & 902 & 652 & 624 \\
\hline 16.0 & 6 & $\mathbf{A}$ & 0 & $=20$ & 2.32 & 3.07 & 294.4 & 70.2 & 100.0 & 177.1 & 2.0 & 0.25 & 121 & 157 & 267 & 203 & 997 & (7) & 601 \\
\hline 10.0 & 7 & as & 0 & 120 & 2.32 & 3.07 & 307.6 & 70.2 & 104. & 178.1 & 1.0 & 0.25 & ses & 993 & 273 & 201 & 1052 & 701 & 691 \\
\hline 10.0 & 1 & at & 0 & 100 & 2.32 & 3.07 & 352.3 & 96.1 & 190.6 & 11.1 & 5.0 & 0.25 & ess & 503 & 210 & 250 & lase & 750 & sos \\
\hline
\end{tabular}

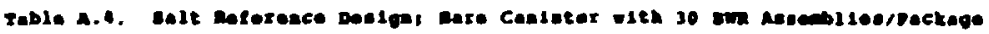

\begin{tabular}{|c|c|c|c|c|c|c|c|c|c|c|c|c|c|c|c|c|c|c|c|}
\hline \multirow[b]{2}{*}{ max } & \multirow[b]{2}{*}{ cans. } & \multicolumn{3}{|c|}{ 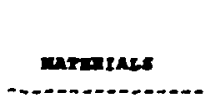 } & \multicolumn{2}{|c|}{$\begin{array}{l}\text { surewnse } \\
\text { te rmerts }\end{array}$} & \multirow{2}{*}{$\begin{array}{l}\text { Cask } \\
\text { aress } \\
\text { (xises) }\end{array}$} & \multicolumn{5}{|c|}{$\begin{array}{l}\text { Drwinstous } \\
\text { In Inctes }\end{array}$} & \multicolumn{4}{|c|}{ 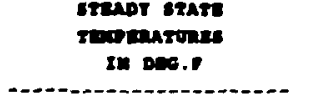 } & \multicolumn{3}{|c|}{ 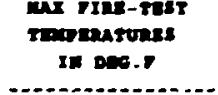 } \\
\hline & & Iment & $\begin{array}{l}\text { ant. } \\
\text { and }\end{array}$ & WIIS & ent. & $\begin{array}{l}\operatorname{man} \\
\sin 0\end{array}$ & & 10 & $\infty$ & Lมตร & $\begin{array}{l}\text { nII } \\
\mathbf{m} .\end{array}$ & TI. & roll & $\begin{array}{l}\text { Inster } \\
\text { wart. }\end{array}$ & $\lim _{\ln x}$ & $\begin{array}{l}\text { Case } \\
\text { sont. }\end{array}$ & ront & $\begin{array}{l}\text { mest } \\
\text { wart }\end{array}$ & Sinco \\
\hline 10.0 & 1 & $\boldsymbol{L}$ & 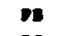 & 120 & 3.37 & 4.25 & 16.0 & 24.7 & 40.4 & 196.0 & 0.0 & 0.0 & 542 & 192 & 190 & 102 & 156 & 13 & 129 \\
\hline 10.0 & 2 & $\mathbf{4}$ & $\boldsymbol{w}$ & 100 & 3.12 & 4.25 & 170.0 & 52.6 & 77.0 & 196.7. & 0.0 & 0.0 & 610 & 283 & 202 & 192 & 720 & 124 & 425 \\
\hline 10.0 & $\mathbf{3}$ & $a b$ & se & $=20$ & 3.72 & 0.25 & 203.9 & 56.5 & 81.0 & 196.7 & 0.0 & 0.0 & 649 & 334 & 223 & 213 & 294 & A2s & 172 \\
\hline 10.0 & 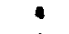 & at & $\boldsymbol{\omega}$ & 520 & 3.72 & 4.25 & 200.8 & 53.2 & 97.6 & 196.7 & 0.0 & 0.0 & 675 & 368 & 242 & 220 & 11 & 530 & 303 \\
\hline 10.0 & 5 & $\mathbf{a b}$ & 18 & 120 & 3.72 & 0.25 & 202.5 & 10.6 & 19.0 & 196.7 & 0.0 & 0.0 & 694 & 393 & 253 & 239 & eje & 367 & 525 \\
\hline 10.0 & 6 & $a b$ & $\boldsymbol{m e}$ & 120 & 3.72 & 0.25 & 327.3 & 20.2 & 102.7 & 196.7 & 0.0 & 0.0 & 100 & 112 & 266 & 246 & 153 & see & $\operatorname{sen} 2$ \\
\hline 10.0 & 1 & $a b$ & $\theta$ & 120 & 1.01 & 3.75 & $\bullet 7.1$ & 20.7 & 32.1 & 199.7 & 0.0 & 0.0 & 531 & 106 & 106 & 170 & 687 & 3st & 373 \\
\hline 10.0 & 2 & as & $\boldsymbol{1 0}$ & 1020 & 0.99 & 3.15 & 196.7 & 32.6 & 01.0 & 200.7 & 0.0 & 0.0 & 107 & 279 & 190 & 109 & 700 & 001 & 100 \\
\hline 10.0 & J & ab & $r$ & $=20$ & 6.99 & 3.75 & 221.5 & 56.5 & es. 0 & 200.7 & 0.0 & 0.0 & 644 & 320 & 220 & 200 & 769 & 470 & 435 \\
\hline 10.0 & 4 & AL & 10 & 120 & e. 94 & 3.73 & 259.0 & 63.2 & 01.1 & 200.7 & 0.0 & 0.0 & 670 & 362 & 237 & 223 & 794 & 313 & 167 \\
\hline 10.0 & 5 & AL & $\pi$ & 120 & 0.95 & 3.75 & 303.1 & 70.6 & 99.0 & 200.7 & 0.0 & 0.0 & 609 & 306 & 250 & 234 & 117 & 543 & 190 \\
\hline 10.0 & 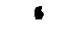 & al & $\boldsymbol{t}$ & 120 & e. 99 & 3.13 & 349.6 & 70.2 & 106.7 & 200.1 & 0.0 & 0.0 & 103 & 109 & 260 & 243 & 134 & 563 & 500 \\
\hline 10.0 & 1 & al & $\mathbf{0}$ & 120 & 2.11 & 3.41 & 67.6 & 24.7 & 42.0 & 190.1 & 0.0 & 0.0 & 5 & 190 & 197 & 109 & 706 & 160 & 163 \\
\hline 10.6 & 2 & ab & $\boldsymbol{\sigma}$ & $=20$ & 2.32 & 3.47 & 163.2 & 52.6 & 71.1 & 390.0 & 0.0 & 0.0 &, 13 & 201 & 207 & 198 & 737 & 134 & 149 \\
\hline 10.0 & 3 & AL & 0 & 120 & 2.32 & 3.11 & 100.4 & 36.5 & 75.1 & 190.1 & 0.0 & 0.0 & 652 & 330 & 232 & 220 & 784 & 507 & 190 \\
\hline 10.0 & 4 & at & $\boldsymbol{0}$ & 520 & 2.32 & 3.47 & 224.2 & 63.2 & 01.0 & 190.0 & 0.0 & 0.0 & 670 & 173 & 230 & 236 & 126 & 550 & 320 \\
\hline 10.0 & 5 & at & $u$ & 120 & 2.32 & 3.17 & 264.3 & 70.6 & 09.1 & 190.0 & 0.0 & 0.0 & 697 & 390 & 203 & 247 & 147 & 570 & 350 \\
\hline 10.0 & 6 & $a b$ & $\boldsymbol{\sigma}$ & 120 & 2.32 & 3.47 & 312.6 & 70.2 & 100.0 & 190.1 & 2.0 & 0.21 & 691 & 309 & 239 & 221 & 160 & 352 & ses \\
\hline 10.0 & 1 & al & $\mathbf{0}$ & 1120 & 2.32 & 3.01 & 320.2 & 10.2 & 100.0 & 190.0 & 2.0 & 0.25 & 111 & 126 & 253 & 233 & 905 & 647 & 610 \\
\hline
\end{tabular}




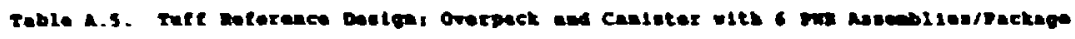

\begin{tabular}{|c|c|c|c|c|c|c|c|c|c|c|c|c|c|c|c|c|c|c|c|}
\hline \multirow[b]{2}{*}{$\begin{array}{l}\text { rotet } \\
\text { Afos }\end{array}$} & \multirow{2}{*}{ cons. } & \multicolumn{3}{|c|}{ marteras. } & \multicolumn{2}{|c|}{$\begin{array}{l}\text { twrcouses } \\
\text { In Incers }\end{array}$} & \multirow{2}{*}{$\begin{array}{l}\text { crsa } \\
\text { weres } \\
\text { (ares) }\end{array}$} & \multicolumn{5}{|c|}{$\begin{array}{l}\text { prinerons } \\
\text { In Inches }\end{array}$} & \multicolumn{4}{|c|}{ 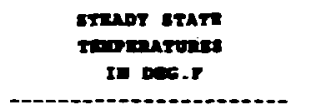 } & \multicolumn{3}{|c|}{ 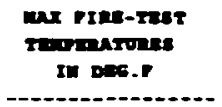 } \\
\hline & & Imrex & $\begin{array}{l}\operatorname{con} . \\
\sin 0\end{array}$ & $\begin{array}{l}\text { met } \\
\text { saro }\end{array}$ & ant. & Der & & ID & $\infty$ & trm & $\begin{array}{l}\text { FIn } \\
\text { rx. }\end{array}$ & rin. & pret & $\begin{array}{l}\text { Intar } \\
\text { wet. }\end{array}$ & ame & $\begin{array}{l}\text { caser } \\
\text { enses. }\end{array}$ & $\begin{array}{l}\text { rota } \\
\text { ora }\end{array}$ & $\begin{array}{l}\text { Imet } \\
\text { ae } 6\end{array}$ & cins \\
\hline 10.0 & 1 & $\boldsymbol{N}$ & $\mathbf{p e}$ & $=20$ & 3.37 & $4.2^{\circ}$ & 5.0 & 21. & 51.5 & 108.7 & 0.0 & 0.0 & 399 & 171 & 170 & 165 & 596 & 318 & 317 \\
\hline 10.0 & 2 & $\mathbf{N}$ & $\mathbf{m}$ & 120 & 3.37 & 0.25 & 174.6 & 50.9 & 02.6 & 108.1 & 0.0 & $\bullet . \bullet$ & 947 & 230 & 171 & 112 & 550 & 303 & 310 \\
\hline 10.0 & 1 & $\boldsymbol{\mu L}$ & $\mathbf{n}$ & 120 & 3.57 & 1.25 & 196.1 & 53.3 & 67.1 & 108.7 & 0.0 & 0.0 & 975 & 262 & 193 & 105 & 596 & 397 & 005 \\
\hline 10.0 & $\bullet$ & $\boldsymbol{N}$ & ve & 1020 & 3.37 & 0.25 & 229. & 10.0 & 90.5 & 100.7 & 0.0 & $\bullet .0$ & 195 & 286 & 205 & 185 & 622 & 20 & 127 \\
\hline$i 0.0$ & s & AL & $\mathbf{p}$ & $m 2 c$ & 3.37 & 1.25 & 260.0 & 79.1 & 102.0 & 100.7 & 0.0 & 0.0 & 509 & 103 & 213 & 203 & 638 & 949 & 443 \\
\hline 10.0 & 6 & aL & $\mathbf{m}$ & 120 & 3.37 & 1.25 & 311.6 & 91.1 & 111.4 & 100.7 & 0.0 & 0.0 & 520 & 316 & 220 & 209 & 649 & 463 & asc \\
\hline 10.0 & 1 & $\boldsymbol{A L}$ & $\mathbf{p e}$ & $m 20$ & 3.37 & 0.25 & 316.6 & 01.1 & 111. & 108.1 & 0.0 & 0.0 & 543 & 343 & 232 & 220 & 6es & 505 & 19 \\
\hline 10.0 & 1 & $\boldsymbol{A L}$ & $\mathbf{n}$ & 1020 & 0.46 & 3.75 & 26.1 & 21.0 & 55.2 & 192.0 & 0.0 & 0.0 & 396 & 167 & 161 & 162 & 529 & 310 & 324 \\
\hline 10.0 & 2 & $\boldsymbol{\Lambda L}$ & $n$ & 1120 & 0.96 & 1.75 & 151.0 & se.- & 06.3 & $: 92.1$ & 0.0 & $\bullet . \bullet$ & 45: & 223 & 175 & 169 & 532 & 324 & 334 \\
\hline 10.6 & 3 & AL & $n$ & 120 & 0.06 & 3.15 & 213.2 & 63.3 & 90.7 & 192.0 & 0.0 & 0.0 & 912 & 259 & 190 & 183 & 576 & 376 & 360 \\
\hline 10.0 & 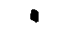 & AL. & $t 5$ & 1020 & 8.46 & 3.75 & 248.0 & 10.0 & 98.2 & 192.4 & 0.0 & 0.0 & ด1 & 202 & 201 & 193 & 603 & 108 & 392 \\
\hline 10.0 & 3 & AL. & $\mathbf{n}$ & 1020 & 0.46 & 3.15 & 209.1 & 19.1 & 106.5 & 192.4 & 0.0 & 0.0 & 505 & 290 & 210 & 200 & 620 & 129 & 909 \\
\hline 10.0 & 6 & AL. & Is & 1020 & 0.46 & 3.75 & 333.7 & 07.7 & 115.1 & 192.0 & 0.0 & 0.0 & 516 & 312 & 211 & 206 & 633 & 045 & 122 \\
\hline 10.0 & 7 & AL & $n$ & 1020 & 0.46 & 3.15 & 336.0 & 67.7 & 115.1 & 192.4 & c.o & 0.0 & 539 & 339 & 229 & $\therefore 16$ & 666 & 984 & 946 \\
\hline 10.0 & 1 & AL & 0 & 1020 & 2.13 & 3.47 & 66.6 & 27.0 & 16.0 & 103.2 & 0.0 & $\bullet .0$ & 403 & 175 & 174 & 69 & 622 & 407 & 406 \\
\hline 10.0 & 2 & AL. & 0 & $m 2 n$ & 2.11 & 3.47 & 160.8 & se. & 77.1 & 103.2 & 0.0 & 6.0 & 499 & 231 & 101 & 175 & 551 & 350 & 392 \\
\hline 10.0 & 3 & AL. & 0 & $m 20$ & 2.11 & 3.47 & 181.3 & 63.3 & 01.5 & 103.2 & 0.0 & 0.0 & are & $: 66$ & 198 & 190 & 604 & 106 & 427 \\
\hline 10.0 & 4 & $\mathbf{N}$ & 0 & 1020 & 2.13 & 3.47 & $2: 3.0$ & 20.0 & 19.0 & 103.2 & 0.0 & 0.0 & 497 & 2.' & 209 & 200 & 628 & 431 & 445 \\
\hline 10.0 & 5 & $\mathbf{A L}$ & 0 & 120 & 2.11 & 3.47 & 251.3 & 79.1 & 97.3 & 183.2 & 0.0 & 0.0 & 582 & 305 & 210 & 208 & 646 & 151 & 466 \\
\hline 10.0 & 6 & $\overline{\mathbf{A L}}$ & 0 & 1020 & 2.13 & 3.47 & 292.5 & 07.7 & 105.9 & .03 .2 & 0.0 & 0.0 & 323 & 31 & 225 & 215 & 651 & 17 & 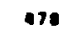 \\
\hline 10.0 & 7 & AI & 0 & 120 & 2.13 & 3.47 & 297.6 & 07.7 & 105.8 & 103.2 & 0.0 & 0.0 & 586 & 347 & 230 & 226 & 694 & 514 & 502 \\
\hline 10.0 & 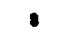 & $\mathbf{M L}$ & v & 1120 & 2.13 & 3.41 & 302.1 & 96.5 & 114.7 & 103.2 & 0.0 & 0.0 & $\$ 52$ & 355 & 242 & 230 & 696 & 510 & sos \\
\hline
\end{tabular}

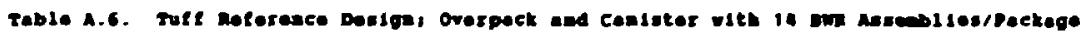

\begin{tabular}{|c|c|c|c|c|c|c|c|c|c|c|c|c|c|c|c|c|c|c|c|}
\hline \multirow[b]{2}{*}{$\begin{array}{l}\text { rus } \\
\text { ias }\end{array}$} & \multirow{2}{*}{ cans. } & \multicolumn{3}{|c|}{ natringals } & \multicolumn{2}{|c|}{$\begin{array}{l}\text { Imtconss: } \\
\text { In Incues }\end{array}$} & \multirow{2}{*}{$\begin{array}{l}\text { exix } \\
\text { werary } \\
\text { (xLes) }\end{array}$} & \multicolumn{5}{|c|}{ 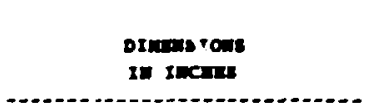 } & \multicolumn{4}{|c|}{ 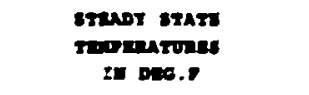 } & \multicolumn{3}{|c|}{ 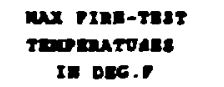 } \\
\hline & & Insert & $\begin{array}{l}\text { CNK. } \\
\text { smbo }\end{array}$ & $\begin{array}{l}\text { weos } \\
\text { sabr }\end{array}$ & CAN. & $\begin{array}{l}\text { wert } \\
\text { SELO }\end{array}$ & & ID & no & tentit & rin. & irix. & roek & $\begin{array}{l}\text { suser } \\
\text { murb }\end{array}$ & $\operatorname{arm}$ & $\begin{array}{l}\text { case } \\
\text { sons. }\end{array}$ & $\begin{array}{l}\text { ruse } \\
\text { IIn }\end{array}$ & $\begin{array}{l}\text { Insm } \\
\text { wrt }\end{array}$ & $\begin{array}{l}\text { CNouk } \\
\text { SALD }\end{array}$ \\
\hline 10.0 & 1 & $A b$ & $\mathbf{m}$ & $=20$ & 3.37 & 0.25 & 87.7 & 27.0 & 51.5 & 210.2 & 0.0 & 0.0 & 329 & 150 & 150 & $1: 1$ & s:s & 352 & 352 \\
\hline 10.0 & 2 & AL & 93 & $\pi 20$ & 3.37 & 0.25 & 201.6 & 50.9 & 22.6 & 210.2 & 0.0 & 0.0 & 362 & 191 & 163 & 159 & 456 & 299 & 341 \\
\hline 10.0 & 3 & AL & 1 & $=20$ & 3.37 & 4.25 & 226.1 & 63.3 & er. 1 & 210.2 & 0.0 & 0.0 & 312 & 220 & 174 & 169 & 493 & 341 & 367 \\
\hline 10.0 & : & AL & $\boldsymbol{1 0}$ & $m 20$ & 3.37 & .25 & 260.9 & 10.8 & 94.5 & 210.2 & 0.0 & 0.0 & 396 & 231 & 102 & 116 & 313 & 365 & 365 \\
\hline 10.0 & 5 & $A L$ & 90 & $=20$ & 3.37 & 4.25 & 309.7 & 79.1 & 102.0 & 210.2 & 0.0 & 0.0 & 407 & 248 & 10s & 102 & 526 & 300 & 390 \\
\hline 10.0 & 6 & AL & 18 & 120 & 3.37 & 0.25 & 350.2 & 87.1 & 111.1 & 210.2 & 0.0 & 0.0 & 115 & 2so & 193 & 186 & 530 & 390 & .07 \\
\hline 10.0 & 1 & AL & 18 & $\mathbf{m 2 0}$ & 6.46 & 3.75 & 99.4 & 27.0 & 53.2 & 221.9 & 0.0 & 0.0 & 327 & 156 & 156 & 152 & 149 & 245 & 299 \\
\hline 10.0 & 2 & $A L$ & 1 & 120 & 0.16 & 3.75 & 219.7 & se. & 06.3 & 221.9 & 0.0 & 0.0 & 360 & 195 & 161 & 157 & 130 & 200 & 305 \\
\hline 10.0 & $\mathbf{3}$ & Ab & re & $m 20$ & 0.46 & 3.75 & 245.2 & 63.3 & 90.7 & 221.9 & 0.0 & 0.0 & 300 & 210 & 172 & 167 & 47 & 321 & 332 \\
\hline 10.0 & 4 & AL & 1: & 120 & 0.46 & $3 .: 4$ & 285.7 & 10.0 & 96.2 & 221.9 & 0.0 & 0.0 & 394 & 234 & 100 & 170 & 190 & 345 & 350 \\
\hline 10.0 & 3 & AL & res & $m 20$ & 0.46 & $3.1 \mathrm{~s}$ & 332,3 & 79.1 & 106.5 & 221.9 & 1.0 & 0.0 & 104 & 296 & 106 & 179 & 500 & 361 & 384 \\
\hline 10.0 & 1 & AL & 0 & $m 20$ & 2.13 & 3.47 & 17.3 & 27.0 & 46.0 & 212.7 & 0.0 & 0.0 & 331 & 161 & 161 & 197 & 541 & 379 & 310 \\
\hline 10.0 & 2 & AL & 0 & $\mathbf{m 2 0}$ & 2.13 & 3.47 & $10: .5$ & 58.1 & 77.1 & 212.7 & 0.0 & 0.0 & 363 & 198 & 165 & 161 & 162 & 105 & 361 \\
\hline 10.0 & J & AL & $\mathbf{u}$ & 120 & 2.13 & 3.97 & 209.6 & 63.3 & 01,9 & 212.7 & 0.0 & 0.0 & 100 & 222 & 171 & 112 & 300 & 389 & 308 \\
\hline 10.0 & 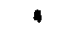 & AL & $\mathbf{u}$ & $m 20$ & 2.13 & 3,07 & 207.0 & 10.0 & 10.0 & 212.7 & 0.0 & 0.0 & 390 & 239 & ies & 179 & 520 & 373 & 106 \\
\hline 10.0 & 5 & AL & 0 & 1120 & 2.13 & 3.47 & 200.3 & 79.1 & 97,1 & 212.7 & 0.0 & 0.0 & 109 & 251 & 192 & 105 & $5 ; 2$ & 307 & 410 \\
\hline 10.0 & 6 & AL & $\mathbf{0}$ & -20 & 2,13 & 3.47 & 317.7 & 17. & 105.8 & 212.7 & 0.0 & 0.0 & 117 & 261 & 157 & 180 & 500 & 397 & 120 \\
\hline
\end{tabular}




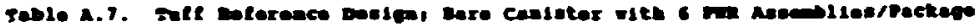

\begin{tabular}{|c|c|c|c|c|c|c|c|c|c|c|c|c|c|c|c|c|c|c|c|}
\hline \multirow[b]{2}{*}{$\operatorname{mans}$} & \multirow[b]{2}{*}{ eine. } & \multicolumn{3}{|c|}{ Mrimines } & \multicolumn{2}{|c|}{$\begin{array}{l}\text { Ficouses } \\
\text { In rucies }\end{array}$} & \multirow{2}{*}{$\begin{array}{l}\text { ent } \\
\text { weter } \\
\text { (Exas) }\end{array}$} & \multicolumn{5}{|c|}{$\begin{array}{l}\text { Dyusions } \\
\text { In rocis }\end{array}$} & \multicolumn{4}{|c|}{ 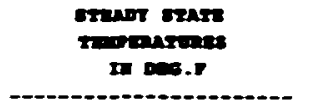 } & \multicolumn{3}{|c|}{ 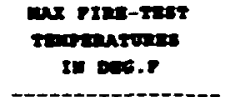 } \\
\hline & & mens & can. & סיהם & Den. & קוח & & IE & $\infty$ & Lenen & rIm & tru & ron & $\begin{array}{l}\ln x \\
\operatorname{man}\end{array}$ & $\min _{\min }$ & cting & $\begin{array}{l}\text { mer } \\
\text { In }\end{array}$ & $\begin{array}{l}\max \\
\max \end{array}$ & con \\
\hline 10.0 & 1 & $\mathbf{A L}$ & $m$ & map & 3.62 & 6.23 & se.6 & 23.0 & 9. 3 & 182.7 & $\bullet .0$ & 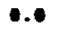 & 424 & 174 & 173 & 167 & 631 & 305 & 303 \\
\hline 10.0 & a & AL & $m$ & $=20$ & 3.62 & 0.25 & 154.2 & 53.3 & 77.6 & 182.7 & 0.0 & $1 . \bullet$ & 97 & 239 & 101 & its & sen & 359 & 370 \\
\hline 10.0 & $\mathbf{3}$ & $\mathbf{A L}$ & $m$ & $=20$ & 3.62 & 0.23 & 172.4 & 57.4 & 01.6 & 182.7 & -.0 & $\bullet .0$ & 507 & 276 & 199 & 190 & 631 & 411 & 415 \\
\hline 80.0 & a & $\mathbf{A L}$ & $\mathbf{m}$ & $m$ & 3.62 & 0.25 & 201.1 & 60.1 & อ.. & 102.1 & $\bullet$. & .0 & 530 & 302 & 211 & 201 & 659 & 950 & 439 \\
\hline 10.0 & 3 & $\boldsymbol{A L}$ & $m$ & 20 & 3.62 & 0.25 & 234.2 & 11.6 & 93.9 & 102.7 & 0.0 & 1.0 & 544 & 321 & 221 & 209 & 676 & 473 & Ass \\
\hline 10.0 & 6 & $\boldsymbol{A L}$ & $\mathbf{m}$ & 120 & 3.62 & 0.23 & 210.0 & 19.4 & 103.6 & 102.7 & 0.0 & 0.0 & 555 & 336 & 229 & 216 & ces & aee & Are \\
\hline 10.0 & 7 & $\mathbf{A L}$ & $m$ & 120 & 3.62 & T.2s & 274. & 19.4 & 103.6 & 102.7 & 0.0 & $\bullet .0$ & 500 & 365 & 242 & 227 & 126 & 532 & 989 \\
\hline 10.0 & $\bullet$ & $\boldsymbol{\Lambda}$ & $m$ & $=20$ & 3.62 & 0.25 & 313.7 & 01.3 & 111.6 & 102.7 & 0.0 & $\bullet . \bullet$ & ser & 373 & 241 & 212 & 129 & 330 & 502 \\
\hline 10.0 & 1 & $\boldsymbol{a L}$ & re & D20 & 0.05 & 3.75 & 79.0 & 25.0 & 33.2 & 186.7 & $\bullet . \bullet$ & $\bullet .0$ & 120 & 170 & 189 & 164 & 552 & 313 & 325 \\
\hline 10.0 & $\mathbf{2}$ & $\mathbf{A L}$ & $m$ & 120 & 0.05 & 3.73 & 110.0 & 53.3 & 61.5 & 106.7 & 0.0 & $\bullet . \bullet$ & are & 233 & 170 & 172 & 56 & 330 & 341 \\
\hline 19.0 & 3 & $\mathbf{a L}$ & $m$ & w20 & 0.93 & 3.75 & 189.0 & 57.4 & 05.6 & 106.7 & $\bullet .0$ & $\bullet .0$ & 504 & 212 & 195 & 187 & GdS & 393 & 370 \\
\hline 180 & $\bullet$ & $\boldsymbol{a}$ & $m$ & $\infty$ & 0.05 & 3.75 & 219.1 & 69.1 & 92.3 & 106.7 & $\omega .0$ & 6.0 & 324 & 297 & 205 & 197 & 637 & 427 & 603 \\
\hline 10.0 & $=$ & as. & $\boldsymbol{n}$ & $m 20$ & 0.05 & 3.75 & 233.7 & 11.6 & 99.0 & 186.7 & 0.0 & $\bullet . \bullet$ & 339 & 316 & 211 & 206 & 656 & as1 & 121 \\
\hline 10.0 & 6 & al & $n$ & mo & 0.65 & 3.75 & 251.5 & 75.4 & 167.6 & 106.7 & 0.0 & $\bullet . \bullet$ & 531 & 30 & 224 & 212 & 670 & 460 & 136 \\
\hline 10.0 & 1 & al & re & 120 & c.es & 3.75 & asc.1 & 19.4 & 187.6 & .86 .7 & $\bullet . \bullet$ & $\bullet .8$ & 373 & 359 & 237 & 223 & res & ses & ase \\
\hline 10.0 & $\bullet$ & $\mathbf{A L}$ & $\boldsymbol{n}$ & 120 & 0.05 & 3.75 & 336.7 & 07.3 & 113.5 & 186.1 & 0.0 & $\bullet . \bullet$ & 512 & 368 & 242 & 221 & 710 & 587 & 469 \\
\hline 10.0 & 1 & al & - & ב20 & 2.27 & 3.07 & 59.5 & 25.8 & 03.5 & 171.0 & 0.0 & 0.0 & 021 & 119 & 178 & 112 & ces & ois & 413 \\
\hline 10.0 & 2 & al & 0 & 120 & 2.27 & 3.47 & 190.6 & 53.3 & 11.0 & 171.0 & 0.0 & $\bullet .0$ & (19) & 242 & 105 & 178 & 591 & 360 & 100 \\
\hline 10.0 & 3 & aL & $\boldsymbol{t}$ & 120 & 2.27 & 3.47 & 150.1 & 37.4 & 15.9 & 171.0 & 0.0 & 0.0 & 510 & 205 & 204 & 195 & sete & 127 & 40 \\
\hline 10.0 & $\bullet$ & $\mathbf{A L}$ & $\nabla$ & 120 & 2.27 & 3.97 & tes.7 & 64.1 & 62.6 & 171.0 & 0.0 & 0.0 & S31 & 306 & 217 & 201 & 66 & 961 & 162 \\
\hline 10.0 & 5 & $\boldsymbol{A L}$ & $\theta$ & 120 & 2.27 & 3.47 & 211.4 & 71.6 & 96.1 & 171.0 & 0.0 & 0.0 & 547 & 325 & 227 & 216 & Ges & 902 & 679 \\
\hline 10.0 & 6 & as & 0 & 120 & 2.27 & 3.47 & 252.2 & 19.4 & 97.9 & $1=7.0$ & 0.0 & 0.0 & 5se & 319 & 234 & 222 & 696 & est & 493 \\
\hline 10.0 & 1 & AL & $\nabla$ & 20 & 2.27 & 3.47 & 256.7 & 19.4 & 97.9 & 171.0 & 0.0 & 0.0 & sej & 369 & 246 & 230 & 735 & 542 & 310 \\
\hline 10.0 & - & $\boldsymbol{A L}$ & 8 & 120 & 2.37 & 3.47 & 294.1 & 07.3 & 105.0 & 171.0 & 6.0 & 0.0 & 590 & 37 & 253 & 239 & 737 & 547 & 325 \\
\hline 9.0 & 9 & AL & 0 & $\mathbf{1 2 0}$ & 2.27 & 3.47 & 334.0 & 15.4 & 113.9 & 171.0 & 6.0 & 0.0 & 595 & 30 & 237 & 243 & 780 & 550 & 532 \\
\hline
\end{tabular}

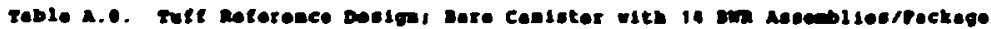

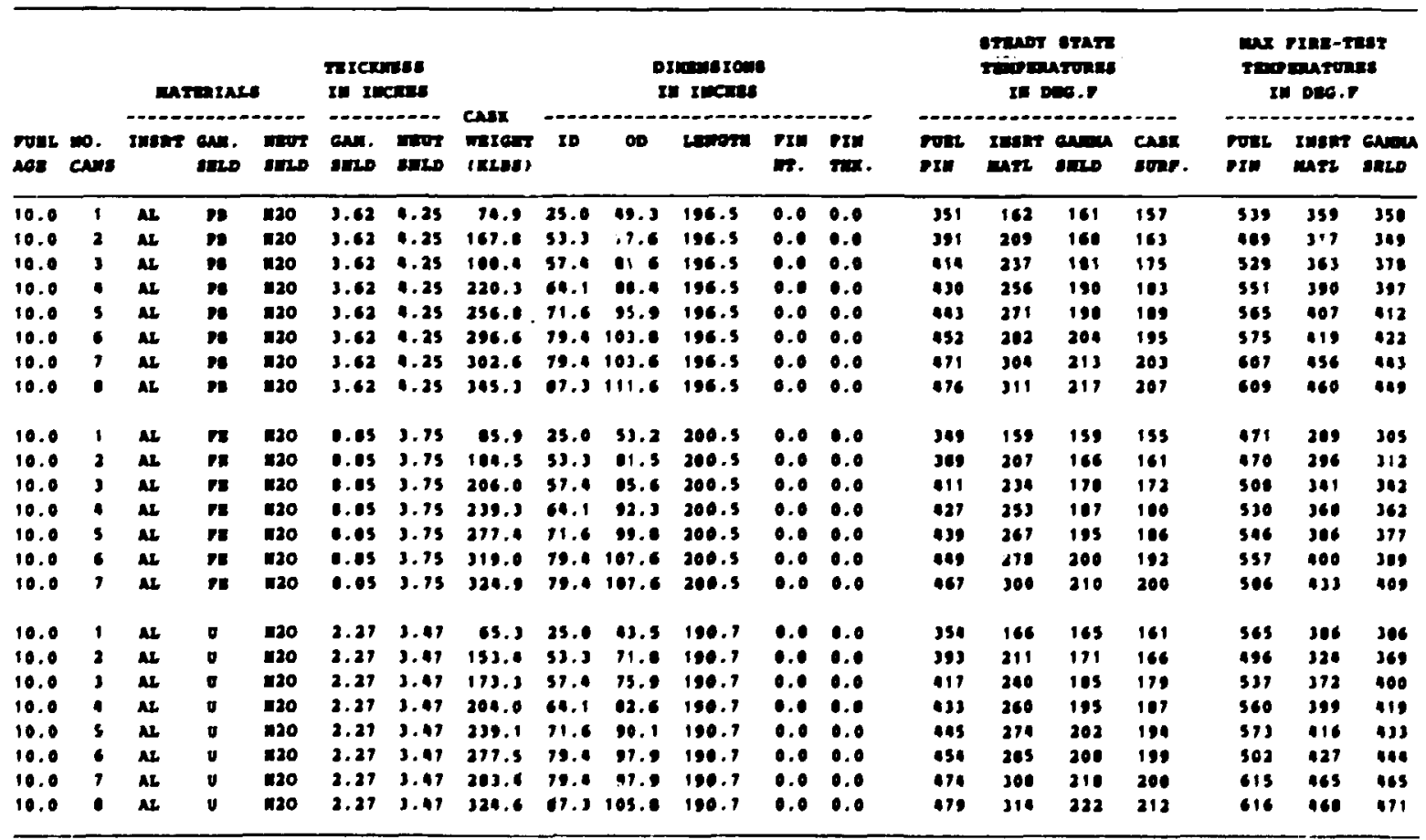




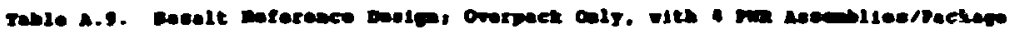

\begin{tabular}{|c|c|c|c|c|c|c|c|c|c|c|c|c|c|c|c|c|c|c|c|}
\hline \multirow[b]{2}{*}{$\operatorname{mex}$} & \multirow{2}{*}{ ens. } & \multicolumn{3}{|c|}{ marreraks } & \multicolumn{2}{|c|}{ Iredises } & \multirow{2}{*}{$\begin{array}{l}\text { con } \\
\text { ander } \\
\text { tanes }\end{array}$} & \multicolumn{5}{|c|}{ 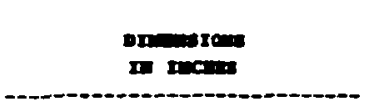 } & \multicolumn{4}{|c|}{ 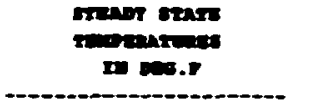 } & \multicolumn{3}{|c|}{ 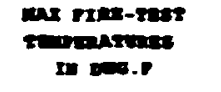 } \\
\hline & & & an. & men & an: & $\min _{\lim }$ & & 10 & $\infty$ & S-m & exin. & II. & in & $\min _{\max }$ & סוג & $\begin{array}{l}\text { exp } \\
\sin .\end{array}$ & Wri & $\begin{array}{l}\text { male } \\
\text { wan }\end{array}$ & ספר \\
\hline 16.0 & 1 & $\bar{s}$ & $m$ & 200 & 1.00 & 0.25 & 16.0 & 26.0 & 40.6 & 181.1 & $\bullet$ & 0.0 & 434 & 166 & 165 & 161 & $\cos$ & 393 & 392 \\
\hline 16.0 & $\mathbf{2}$ & $\boldsymbol{s}$ & $m$ & $\infty$ & 1.00 & 6.25 & 109.0 & 03.3 & 63.9 & 101.1 & $\bullet$. & $\bullet$. & 478 & 220 & 173 & 160 & 507 & $3 \bullet 3$ & 376 \\
\hline 16.0 & 3 & as & $m$ & $=20$ & 1.00 & 4.25 & 121.0 & 96.6 & 67.2 & 181.1 & $\bullet .0$ & $\bullet . \bullet$ & ses & 252 & 101 & 181 & 629 & 393 & a98 \\
\hline 10.6 & $\bullet$ & at & $m$ & 20 & 1.00 & 6.25 & 153.0 & 52.1 & 72.1 & 101.1 & $\bullet .0$ & $\bullet .0$ & 530 & 273 & 198 & 198 & 652 & 922 & 629 \\
\hline 10.0 & $s$ & As & $m$ & 1200 & 1.00 & 4.25 & 180.9 & se. 1 & 70.1 & 101.1 & $\bullet .0$ & $\bullet .0$ & 533 & 209 & 206 & 190 & 666 & 801 & 940 \\
\hline 10.0 & 6 & $\mathbf{L}$ & $\boldsymbol{m}$ & 120 & 1.00 & 0.25 & 210.6 & 64.6 & es. & 101.1 & $\bullet . \bullet$ & 6.0 & 503 & sex & 213 & 204 & 675 & est & 455 \\
\hline 10.0 & 7 & $\boldsymbol{L}$ & $m$ & 1020 & 1.00 & 0.25 & 221.1 & 64.6 & es .e & 281.1 & $\bullet . \bullet$ & 0.0 & 563 & 326 & 220 & 213 & $7 e n$ & 493 & 677 \\
\hline บอ. & e & $\mathbf{A L}$ & $m$ & 120 & 1.00 & 0.25 & 252.5 & 70.6 & 91.4 & 102.1 & $\bullet . \bullet$ & 0.9 & 569 & 334 & 220 & 217 & 110 & 997 & ext \\
\hline 10.0 & 9 & $\boldsymbol{L}$ & $w$ & 120 & 1.00 & 0.25 & 205.5 & 77.3 & 97.9 & 101.1 & $\bullet . \bullet$ & $0 . \bullet$ & 574 & 340 & 232 & 221 & ו1י & see & ต9อ \\
\hline 10. & 10 & AL & $m$ & 120 & 1.00 & 0.25 & 310.2 & 01.2 & :01.0 & 101.1 & $\bullet .0$ & $\bullet . \bullet$ & 592 & 350 & 237 & 226 & 121 & 512 & 990 \\
\hline 10.0 & 11 & AL & $\boldsymbol{m}$ & 100 & 1.00 & 4.25 & 330.1 & 03.6 & 104.4 & 101.1 & $\bullet$ & $\bullet . \bullet$ & 592 & 363 & 248 & 231 & 735 & 529 & 510 \\
\hline 16.0 & 1 & $\mathbf{A L}$ & $n$ & 100 & 5.90 & 3.75 & 53.3 & 26.0 & 92.5 & 102.5 & $\bullet . \bullet$ & $\bullet . \bullet$ & 632 & 160 & 164 & 160 & 590 & 333 & 333 \\
\hline 16.0 & 2 & As & $\mathrm{st}$ & $=20$ & 5.50 & 3.73 & 116.2 & 63.3 & 65.0 & 102.9 & $\bullet .0$ & 0.0 & 976 & 210 & 171 & 167 & 573 & 327 & 330 \\
\hline 10.0 & 3 & $\boldsymbol{\Lambda L}$ & rte & $=20$ & 5.90 & 3.75 & 135.5 & 46.6 & 60.1 & 102. & . 3 & $\bullet . \bullet$ & ser & 209 & I06 & 179 & sta & 376 & 367 \\
\hline x०. & $\bullet$ & AL & $n$ & D20 & 5.90 & 3.75 & 161.3 & 52.1 & 70.5 & $102+3$ & 11.0 & $\bullet . \bullet$ & $\sin$ & 210 & 196 & 189 & 633 & ces & Jee \\
\hline 10.0 & 5 & $\boldsymbol{M L}$ & $\mathrm{nt}$ & $=20$ & 5.90 & 3.75 & 109.9 & Se. 1 & 00.6 & 102.9 & $\bullet . \bullet$ & $\bullet .0$ & 530 & 206 & 200 & 196 & 651 & 124 & aes \\
\hline 10.0 & 6 & $\mathbf{A}$ & $r$ & 120 & 3.50 & 3.75 & 220.5 & 64.6 & 06.1 & 102.9 & $\bullet .0$ & $\bullet .0$ & 380 & 290 & 211 & 202 & 61 & 430 & 417 \\
\hline 16.0 & 7 & AL & $n$ & 120 & 5.90 & 3.75 & 231.0 & 64.4 & 06.9 & 102.8 & 0.0 & $\bullet .0$ & 560 & 322 & 221 & 211 & 691 & 075 & (93) \\
\hline 10.0 & $\bullet$ & $\boldsymbol{L}$ & $\mathrm{st}$ & 120 & 5.90 & 3.75 & 263.2 & 10. & 93.3 & 102.9 & $\bullet . \bullet$ & $\bullet . \bullet$ & 566 & 330 & 226 & 215 & 696 & 001 & 147 \\
\hline 16.0 & $\checkmark$ & AL & $n$ & $n 20$ & 5.90 & 3.75 & 297.0 & 77.3 & $\$ 9.0$ & 102.9 & 0.0 & $\bullet .0$ & 570 & 336 & 229 & 218 & 699 & 926 & 454 \\
\hline 10.0 & 10 & $\boldsymbol{\mu}$ & $r$ & \pm 20 & 3.90 & 3.75 & 322.3 & 01.2 & 103.7 & 102.9 & $\bullet . \bullet$ & $\bullet .0$ & 379 & 346 & 235 & 223 & 709 & 49 & 964 \\
\hline 16.0 & 1 & AL & v & $=20$ & 1.26 & 3.07 & 96.1 & 20.8 & 36.5 & 176.9 & $\bullet . \bullet$ & 0.0 & 437 & 170 & 169 & 165 & 671 & 123 & 423 \\
\hline 10.0 & 2 & $\boldsymbol{M L}$ & 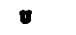 & $=20$ & 1.26 & 3.47 & 102.e & 43.3 & 59.0 & 176.9 & $\bullet .0$ & $\bullet .0$ & 479 & 223 & 176 & 171 & 590 & Jse & נes \\
\hline 10.0 & 3 & AL & 0 & $=20$ & 1.26 & 3.47 & 120.5 & 96.6 & 63.1 & 176.9 & $\bullet . \bullet$ & 6.0 & ses & 255 & 191 & 105 & 637 & 003 & 932 \\
\hline 10.0 & $\bullet$ & $\mathbf{A b}$ & $c$ & $=20$ & 1.26 & 3.67 & 145.2 & 52.1 & 60.5 & 176.9 & 0.0 & $\bullet .0$ & 523 & 276 & 202 & 195 & 660 & 032 & 453 \\
\hline 10.0 & 5 & $\boldsymbol{A L}$ & 0 & $=20$ & 1.26 & 1.47 & 172.4 & 50.1 & 70.6 & 176.9 & 0.0 & $\bullet .0$ & 335 & 292 & 211 & 202 & 673 & ase & oce \\
\hline 10.0 & 6 & Ax & $\nabla$ & 120 & 1.26 & 3.97 & 201. & 64.6 & $\bullet \bullet . \bullet$ & 176.9 & $\bullet .0$ & $\bullet . \bullet$ & sas & $30 s$ & 217 & 200 & 602 & 961 & 479 \\
\hline 10.0 & 7 & $\mathbf{L}$ & D & 120 & 1.26 & 3.47 & 211.9 & 64.9 & 00.9 & 176.8 & 0.0 & 6.0 & 565 & 329 & 229 & 218 & 116 & 502 & 501 \\
\hline 10.0 & - & AL & $\boldsymbol{v}$ & 120 & 1.26 & 3.67 & 242.6 & 70.0 & 07.3 & 176.8 & 0.0 & $\bullet$ & 571 & 337 & 233 & 222 & 111 & ses & 500 \\
\hline 10.0 & 9 & $\mathbf{x}$ & $\nabla$ & 120 & 1.26 & 3.47 & 274.0 & 77.3 & 93.0 & 176.8 & $\bullet . \bullet$ & 1.0 & 576 & 353 & 237 & 226 & 110 & 507 & 510 \\
\hline 10.0 & 10 & $\boldsymbol{\Lambda}$ & 0 & $=20$ & 1.26 & 3.47 & 299.1 & 01.2 & 97.7 & 176.8 & $\bullet .0$ & $\bullet$ & see & 353 & 242 & 230 & 727 & 519 & 521 \\
\hline 10.0 & 11 & Ax & $v$ & 120 & 1.26 & 3.47 & 310.7 & 03.8 & 100.2 & 176.5 & $\bullet .0$ & $\bullet .0$ & ses & 166 & 249 & 236 & 101 & 536 & 534 \\
\hline 10.6 & 12 & $\boldsymbol{A L}$ & $\mathbf{0}$ & 120 & 1.26 & 3.47 & 339.7 & 06.6 & 103.1 & 176.9 & $\bullet . \bullet$ & 0.0 & 60 & 377 & 254 & 241 & 152 & 550 & sas \\
\hline
\end{tabular}




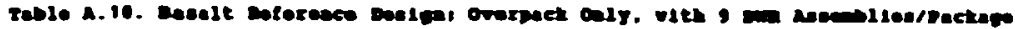

\begin{tabular}{|c|c|c|c|c|c|c|c|c|c|c|c|c|c|c|c|c|c|c|c|}
\hline \multirow[b]{2}{*}{$\begin{array}{l}\text { wit } \\
\text { ats }\end{array}$} & \multirow{2}{*}{ co. } & \multicolumn{3}{|c|}{ 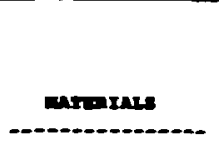 } & \multicolumn{2}{|c|}{$\begin{array}{l}\text { rencess } \\
\text { rw noms }\end{array}$} & \multirow{2}{*}{$\begin{array}{l}\text { car } \\
\text { wrens } \\
\text { cters }\end{array}$} & \multicolumn{5}{|c|}{$\therefore$} & \multicolumn{4}{|c|}{ 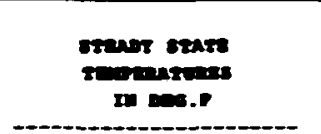 } & \multicolumn{3}{|c|}{ 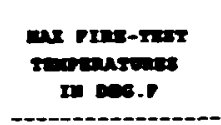 } \\
\hline & & $\operatorname{men}$ & an. & ans & and & ס & & ID & $\infty$ & I.wn & $\begin{array}{l}\mathbf{m} \\
\mathrm{m} .\end{array}$ & $x$ & rm & $\min _{\max }$ & $\cos _{\cos }$ & $\begin{array}{l}\operatorname{cas} x \\
\sin .\end{array}$ & ma & $\begin{array}{l}\text { nors } \\
\text { not }\end{array}$ & $\operatorname{anc}$ \\
\hline 10.0 & 1 & $\boldsymbol{L}$ & $m$ & 20 & 1.00 & 0.25 & 52.2 & 20.0 & 10.6 & 194.0 & 0.0 & 0.0 & 353 & 156 & 155 & 152 & S57 & 360 & 360 \\
\hline 10.0 & 2 & as. & $n$ & nop & 1.80 & 6.25 & 116.5 & 03.3 & 63.9 & 198.6 & 1. & $\bullet .0$ & 303 & 193 & 161 & 157 & aes & 303 & 349 \\
\hline 10.0 & 3 & as & $\omega$ & $=0$ & 1.00 & 4.25 & 136.4 & 96.6 & 67.2 & 184.8 & $\bullet .0$ & $\bullet . \bullet$ & 602 & 216 & 111 & 167 & 510 & 343 & 313 \\
\hline 10.0 & 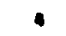 & ax & $\omega$ & 100 & 1.00 & 4.25 & 163.1 & 52.1 & 12.7 & 184.0 & $\bullet .0$ & 0.0 & 415 & 232 & 178 & 17 & 537 & 365 & 309 \\
\hline 10.0 & 5 & $\boldsymbol{N}$ & $m$ & $=0$ & 1.00 & 4.35 & 192.7 & SE.1 & 18.1 & 194.8 & $\bullet .0$ & $\bullet . \bullet$ & 625 & 243 & I0s & 179 & 540 & sis & 505 \\
\hline 10.0 & 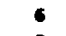 & $\boldsymbol{N}$ & $m$ & $=20$ & 1.00 & 1.25 & 220.3 & 64.4 & 05.6 & 194.0 & 0.0 & $\bullet .0$ & 433 & 252 & 100 & 103 & 550 & 300 & aes \\
\hline 10.0 & 7 & $\boldsymbol{n}$ & Pu & $=20$ & 1.00 & 0.25 & 235.2 & 60.0 & 05.6 & 180.6 & 0.0 & e.e & 190 & 271 & 100 & 190 & 500 & 021 & 427 \\
\hline 10.0 & $\bullet$ & $\boldsymbol{N}$ & $\boldsymbol{n}$ & 120 & 1.00 & 0.25 & 268.6 & 70.6 & 91.4 & 194.0 & $\bullet . \bullet$ & $\bullet . \bullet$ & 452 & 276 & 301 & 193 & ses & 422 & 433 \\
\hline 10.0 & ? & $\boldsymbol{x}$ & $m$ & 120 & 1.00 & 0.25 & 303.6 & 77.3 & 97.9 & 194.0 & 0.0 & 0.0 & 456 & 281 & 204 & 196 & ses & 423 & 637 \\
\hline 10.0 & 10 & $\boldsymbol{N}$ & $\mathbf{1 3}$ & 100 & 1.00 & 1.25 & 329.6 & 11.2 & 101.0 & 190.0 & $\bullet . \bullet$ & $\bullet .0$ & (6) & 205 & 200 & 200 & 500 & 433 & 945 \\
\hline 10.0 & 1 & N & $n$ & $=0$ & 5.90 & 3.75 & 51.0 & 20.0 & 02.5 & 196.8 & 6.6 & $\bullet .0$ & 351 & 150 & 150 & 151 & 69 & 310 & 310 \\
\hline 10.0 & 2 & $\boldsymbol{N}$ & $n$ & $=20$ & 5.80 & 3.75 & 120.2 & 4. & 65.0 & 196.7 & $\bullet . \bullet$ & $\bullet .0$ & 302 & 192 & 160 & 156 & $M$ & Ies & 367 \\
\hline 10.0 & J & $x$ & $n$ & 200 & 5.90 & 3.75 & 104.5 & 46.6 & 69.1 & 196.7 & 1.0 & $\bullet .0$ & 401 & 214 & 170 & 165 & 503 & 326 & 331 \\
\hline 16.0 & $\bullet$ & As & $r$ & $=20$ & 5.91 & 3.75 & - & 52.1 & 70.5 & 196.7 & $\bullet . \bullet$ & $\bullet .0$ & 813 & 229 & 17 & 172 & 521 & jes & 3es \\
\hline 16.0 & $s$ & $\mathbf{A}$ & $n$ & 200 & 5.90 & 3.75 & 262.3 & 50.1 & 10.6 & 196.7 & $\bullet . \bullet$ & $\bullet .0$ & 423 & 241 & 183 & 170 & 533 & 363 & 361 \\
\hline 10.0 & 6 & ax & 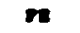 & 100 & 5.90 & 3.75 & 234.7 & 68.0 & 06.1 & 196.7 & 1.0 & $\bullet .0$ & 131 & 290 & 100 & 102 & ses & 373 & ותו \\
\hline 10.0 & 7 & $\mathbf{x}$ & $n$ & $m 20$ & 5.20 & 3.75 & 245.7 & 60.4 & 16.9 & 186.7 & $\bullet$ & $\bullet \bullet$ & eas & 260 & 196 & Ios & 366 & 403 & Jes \\
\hline 10.0 & 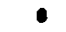 & $\boldsymbol{x}$ & $n$ & 720 & 5.96 & 3.75 & 278.5 & 70.5 & 93.3 & 186.7 & •.- & $\bullet . \bullet$ & 958 & 273 & 198 & 192 & 569 & 901 & Jes \\
\hline 10.0 & 9 & ax & $\omega$ & $=20$ & 5.90 & 3.75 & 315. & n. 3 & 19.8 & 196.7 & $\bullet .0$ & 0.0 & ase & 270 & 202 & 193 & 520 & 110 & see \\
\hline 10.0 & 1 & $\mathbf{x}$ & 0 & 120 & 1.26 & 3.47 & 17.2 & 20.0 & 36.3 & 190.7 & $\bullet . \bullet$ & $\bullet . \bullet$ & 358 & 150 & 130 & 153 & ses & 397 & 397 \\
\hline 10.0 & 2 & $\mathbf{A s}$ & 0 & $m 20$ & 1.26 & 3.01 & 109.1 & (1). & 58.0 & 190.7 & 0.0 & $\bullet .0$ & ses & iss & 163 & 159 & 1 & 310 & 31 \\
\hline 10.4 & $:$ & N & ర & 120 & 1.26 & 3.67 & 120.7 & 16.6 & 63.1 & 190.7 & $\bullet$ & $\bullet . \bullet$ & 964 & 210 & 174 & 169 & 537 & 351 & 396 \\
\hline 10.0 & 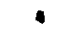 & $\boldsymbol{L}$ & $v$ & 120 & 1.26 & 3.01 & 154.0 & 52.1 & 60.5 & 190.7 & 0.0 & 0.6 & 017 & 230 & 102 & 176 & $\operatorname{sen}$ & 37 & 412 \\
\hline 16.0 & 5 & $\boldsymbol{A}$ & 0 & 120 & 1.26 & 3.41 & 103.7 & so. 1 & 10.5 & 196.7 & $\bullet . \bullet$ & $\bullet . \bullet$ & 027 & 246 & 100 & 102 & 534 & 306 & (2) \\
\hline 10.0 & 6 & $\boldsymbol{x}$ & $\pi$ & 120 & 1.26 & 1.41 & 214.5 & 64.4 & ce.e & Ise.7 & $\bullet .0$ & 0.0 & ass & 255 & [13 & 181 & 580 & 395 & 132 \\
\hline 16.0 & 1 & $\boldsymbol{A}$ & 0 & $=20$ & 1.26 & 3.47 & 225.5 & 64.4 & ט.) & 190.7 & 0.0 & 0.0 & aso & 21) & 202 & 190 & sse & 129 & ise \\
\hline 10.0 & $\bullet$ & $\boldsymbol{\mu L}$ & 0 & $=20$ & 1.26 & 3.47 & 250.1 & 70.0 & e7. & 190.7 & 0.0 & 0.0 & ast & 270 & 205 & 197 & ses & 40 & 456 \\
\hline 10.0 & • & $\boldsymbol{N}$ & $\mathbf{v}$ & 120 & 1.26 & 3.97 & 202.3 & 71.3 & 93.0 & 190.7 & 0.0 & 0.0 & Ast & 203 & 201 & 200 & seo & 40 & 459 \\
\hline 10.0 & 10 & A & 0 & 20 & 1.26 & 3.97 & 310.1 & 01.2 & 97.7 & 190.7 & 0.0 & 6.0 & 965 & 281 & 212 & 203 & 596 & 439 & 467 \\
\hline 10.0 & $: 1$ & $\boldsymbol{M L}$ & 0 & \pm 20 & 1.26 & 3.47 & נ30.0 & 03.0 & 100.2 & 190.7 & 1.0 & $\bullet .0$ & 973 & $\mathbf{3 e 1}$ & $2: 6$ & 207 & 687 & 153 & 476 \\
\hline
\end{tabular}




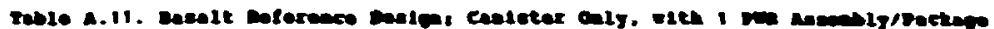

\begin{tabular}{|c|c|c|c|c|c|c|c|c|c|c|c|c|c|c|c|c|c|c|c|}
\hline \multirow[b]{2}{*}{ mit } & \multirow[b]{2}{*}{ ex. } & \multicolumn{3}{|c|}{ wrings } & \multicolumn{2}{|c|}{ noling } & \multirow{2}{*}{ 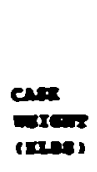 } & 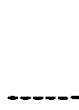 & DI & Imenes & & & & tin & $\operatorname{mat}$ & & $x$ & W.F & $t$ \\
\hline & & $\therefore$ & $\cos$ & ints & an. & סוזים & & $\mathbf{2 0}$ & $\infty$ & enes & 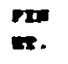 & $x$ & man & nase & Din & case & min & min & and \\
\hline 10.0 & 32 & $\mathbf{A r}$ & $\omega$ & 200 & 0.02 & 6.25 & 190.1 & se. 6 & 79.6 & 103.5 & 0.0 & 0.0 & 991 & 371 & 281 & 226 & 691 & 539 & 9es \\
\hline 10.0 & 33 & $\mathbf{A}$ & $\infty$ & $n$ & 9.62 & 0.25 & 195.6 & 55.0 & 0.0 & 103.5 & 1.0 & 0 & 903 & 373 & 203 & 227 & 642 & 340 & 501 \\
\hline 10.0 & 34 & $\mathbf{A L}$ & 1 & $m$ & 0.02 & 4.25 & 190.2 & 56.3 & 61.3 & 183.5 & 0.0 & $\omega$ & 996 & 377 & 245 & 225 & 68 & 546 & ses \\
\hline 10.0 & 35 & $\mathbf{A L}$ & $\omega$ & 100 & 0.02 & 4.25 & 202.2 & 57.1 & 22.1 & 103.5 & 0.0 & 0.1 & 69 & 301 & 287 & 231 & 658 & $5 s 0$ & sot \\
\hline 16.5 & 36 & $\mathbf{4}$ & $\boldsymbol{n}$ & $\infty 0$ & 4.02 & 1.25 & 201.3 & 50.2 & 03.3 & 103.5 & 0.0 & 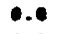 & 501 & 303 & 248 & 232 & 691 & 952 & 510 \\
\hline 10.6 & 37 & $\mathbf{u x}$ & $\omega$ & $\infty$ & $\bullet .02$ & 0.25 & 200.4 & se. 2 & e. 3 & 103.5 & 0.0 & $\bullet$ & sec & 308 & 251 & 234 & 6se & 559 & sis \\
\hline 80.0 & 30 & $\mathbf{A x}$ & $\omega$ & $\infty$ & 0.62 & 0.25 & 211.8 & 50.9 & es. & 103.5 & $\bullet .0$ & $\bullet$. & ses & 392 & 292 & 236 & 662 & 964 & sie \\
\hline 10.6 & 30 & $\mathbf{4}$ & 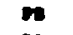 & $\mathbf{m o}$ & 4.02 & $1 . .5$ & 215.0 & 59.7 & 04.7 & 103.5 & 0.0 & $\bullet$ & 311 & 394 & 258 & 237 & 668 & 567 & 520 \\
\hline 10.0 & $\oplus$ & $\boldsymbol{\Delta L}$ & $m$ & 100 &. .02 & 1.25 & 220.7 & 60 & es.0 & 1es.s & 0.0 & $\bullet .0$ & 512 & 396 & 253 & 230 & 666 & 568 & 322 \\
\hline 10.0 & ss & $\mathbf{N}$ & $\omega$ & $\mathbf{m o}$ & 0.02 & 0.25 & 269.0 & 60.1 & 97.1 & 183.5 & 2.0 & 0.35 & 532 & 119 & 245 & 224 & 716 & 625 & 503 \\
\hline 10. & 96 & $\mathbf{A L}$ & $\omega$ & 100 & 4.62 & 4.25 & 290.0 & 73.01 & 102.0 & 103.5 & 2.0 & 0.25 & 522 & 400 & 202 & 221 & 690 & 605 & 575 \\
\hline 16.0 & 57 & $\mathbf{4}$ & $\omega$ & 100 & 0.02 & 4.25 & 296.2 & 74.6 & 103.0 & 103.3 & 2.0 & 6.25 & s23 & 698 & 242 & 222 & 69 & ses & 376 \\
\hline 10.0 & so & $\boldsymbol{A x}$ & $\boldsymbol{\omega}$ & 10 & 1.62 & 0.23 & 291.2 & 74.0 & $103.6-$ & -103.5 & 2.0 & 0.25 & 327 & 113 & 240 & 223 & 703 & 611 & 579 \\
\hline 10.0 & 59 & $\mathbf{A x}$ & $\boldsymbol{n}$ & Dxp & 4.62 & 4.25 & 290.3 & 24.0 & 103.0 & 103.5 & 2.0 & 0.25 & 530 & 017 & 205 & 224 & 700 & 611 & 303 \\
\hline 16.0 & 60 & $\mathbf{A}$ & $\omega$ & 50 & 1.62 & 0.25 & 295.3 & 79.6 & 103.0 & 103.5 & 2.0 & 0.25 & 533 & 021 & 201 & 226 & 113 & 632 & 906 \\
\hline 16.0 & 61 & $\mathbf{A I}$ & $\omega$ & 00 & 1.02 & 0.25 & 302.5 & 28.5 & 103.5 & 183.5 & 2.0 & 0.25 & s3s & 423 & 240 & 226 & 715 & 625 & see \\
\hline 10.0 & 6 & $\mathbf{s}$ & $n$ & 100 & 1.02 & 0.23 & 306.4 & 73.2 & 164.2 & 103.5 & 2.0 & 0.25 & 537 & 25 & 249 & 221 & 717 & 621 & ses \\
\hline 10.0 & 63 & $\mathbf{x}$ & $n$ & 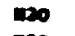 & 1.02 & 4.25 & 307.5 & 75.2 & 104.2 & 103.5 & 3.0 & 0.25 & 580 & 128 & 250 & 220 & 722 & 633 & 592 \\
\hline 10.0 & 69 & $\mathbf{L L}$ & $\omega$ & 1020 & 0.02 & 0.25 & 312.0 & 76.0 & 105.1 & 103.5 & 2.0 & 0.25 & 541 & 011 & 251 & 229 & 723 & 630 & 580 \\
\hline 10.0 & 69 & $\mathbf{A}$ & $\boldsymbol{n}$ & 20 & 4.02 & 0.25 & 315.3 & 76.5 & 185.6 & 103.5 & 2.6 & 0.25 & 943 & 63 & 252 & 230 & 725 & 636 & 596 \\
\hline 10.0 & 66 & $\mathbf{A r}$ & $\omega$ & Dיס & 0.02 & $\bullet .25$ & 318.1 & 17.2 & 106.2 & 103.5 & 2.0 & 0.25 & ses & ass & 253 & 230 & 127 & 638 & 597 \\
\hline 10.0 & 67 & $\mathbf{A x}$ & $\boldsymbol{n}$ & $\omega 20$ & 4.02 & 1.25 & 320.1 & 17.2 & 106.2 & 103.5 & 2.0 & 0.23 & 543 & 439 & 2ss & 232 & 711 & 603 & 600 \\
\hline 16.0 & 21 & $\boldsymbol{M}$ & $\boldsymbol{E}$ & 120 & $\$ .30$ & 3.75 & 106.2 & 50.0 & 79.6 & 207.0 & $\bullet . \bullet$ & 1.0 & 970 & 346 & 226 & 213 & 597 & 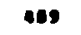 & 44 \\
\hline 10.0 & 26 & $\mathbf{A}$ & $n$ & no & פנ. & 3.75 & 109.8 & 31.1 & 10.4 & 107.0 & $\bullet . \bullet$ & $\bullet . \bullet$ & 913 & 3se & 220 & 214 & 601 & 69 & 94 \\
\hline 16.0 & 28 & $M$ & $n$ & $=20$ & 5.10 & 3.25 & 190.2 & s2.0 & e1. & 107.0 & $\bullet .0$ & 0.1 & 476 & 354 & 230 & 216 & 645 & ass & 451 \\
\hline 10.0 & 30 & 46 & $n$ & $n 20$ & 90 & 3.75 & 196.8 & 52.9 & 01.7 & 102.8 & $\bullet \bullet$ & 0.0 & 900 & Jse & 232 & 210 & 610 & ses & ise \\
\hline 16.0 & 31 & $\mathbf{A}$ & $n$ & 120 & 9.30 & 3.75 & 197.9 & 52.5 & e1. & 107.0 & 0.0 & 0.0 & 106 & 365 & 235 & 220 & 617 & 510 & 961 \\
\hline 10.0 & 32 & 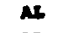 & $n$ & 120 & 9.19 & 3.75 & 206.7 & 54.6 & 03.0 & 107.0 & $\bullet .0$ & 0.0 & 465 & 364 & 235 & 221 & 616 & 512 & 061 \\
\hline 10.0 & 3 & $\boldsymbol{M}$ & $n$ & $=20$ & 9.31 & 3.78 & 212.3 & 55.0 & Cs.t & 187.0 & $\bullet$ & 0.0 & 11 & 166 & 237 & 222 & cie & 514 & 160 \\
\hline 10.0 & 34 & $\mathbf{A L}$ & $n$ & 100 & 9.39 & 3.75 & 215.8 & 56.3 & 15.6 & 187.0 & 0.0 & 0.0 & 490 & 376 & 235 & 224 & 622 & 519 & 960 \\
\hline 10.0 & 35 & 4 & $n$ & $=20$ & 0.10 & 3.75 & 219.2 & 37.1 & 06.4 & 107.8 & $\bullet . \bullet$ & 0.0 & 403 & 373 & 280 & 225 & 626 & 523 & 11 \\
\hline 10.0 & 50 & $\boldsymbol{N}$ & $n$ & 200 & 9.39 & 3.15 & 275.5 & 67.4 & 96.7 & 107.0 & 0.0 & 1.0 & 530 & 111 & 263 & 245 & 671 & 511 & sit \\
\hline 10.0 & 51 & $\mathbf{M}$ & $n$ & 120 & 9.19 & 3,15 & 279.6 & 60.1 & 97.4 & 101.- & 0.0 & 0.0 & 532 & 420 & 265 & 286 & 674 & see & 513 \\
\hline 10.0 & 52 & $\mathbf{A}$ & $n$ & 720 & 9.39 & 3.75 & 200.7 & 60.1 & 91.4 & 101.0 & $\bullet .0$ & $\bullet$ & 536 & 125 & 267 & 248 & 675 & sec & 911 \\
\hline 10.0 & 53 & $\mathbf{A L}$ & $n$ & 120 & 9.39 & 3.75 & 201.7 & $6 e .1$ & 91.4 & 181.0 & $\bullet .0$ & 0.6 & sos & 628 & 269 & 250 & 604 & 592 & 321 \\
\hline 16.0 & 94 & $\mathbf{A b}$ & $n$ & 120 & 0.39 & 3.75 & 200.0 & $6 e .1$ & 101.1 & 201.0 & 2.0 & 0.25 & 522 & 100 & 230 & 210 & 600 & 391 & 530 \\
\hline 10.0 & ss & $\mathbf{A}$ & $n$ & 230 & 0.19 & 3.75 & 209.1 & 60.1 & 101.4 & 101.0 & 2.0 & 0.25 & 526 & 112 & 238 & 218 & ces & 596 & 941 \\
\hline 10.0 & 96 & $\Delta$ & $n$ & 920 & 1.39 & 3.75 & 305.6 & 73.0 & 102.2 & 101.0 & $\bullet .0$ & 0.0 & 539 & 927 & 269 & 250 & 600 & 500 & 921 \\
\hline 14,0 & 57 & A & $n$ & 10 & 0.39 & 3.75 & 316.1 & 24.0 & 101.3 & 107.0 & 2.0 & 0.25 & 510 & 103 & 231 & 211 & 676 & 581 & 535 \\
\hline 10.0 & se & $\boldsymbol{N}$ & $n$ & $=20$ & 9.39 & 3.75 & 311.7 & 74.6 & 101.3 & 107.0 & 2.0 & 0.25 & 521 & 467 & 230 & 218 & 606 & 507 & $\$ 30$ \\
\hline 10.0 & 59 & AL & $n$ & 200 & 1.39 & 3.75 & 110.0 & 24.0 & 101.3 & 101.0 & 2.0 & 3.25 & sas & 110 & 240 & 229 & ses & 502 & 542 \\
\hline 16.0 & 6 & $\mathbf{M}$ & $n$ & mo & 9.39 & 3.75 & 319.0 & 76.0 & 101.3 & 107.0 & 2.0 & 0.25 & 528 & 114 & 202 & 221 & 609 & 597 & ses \\
\hline 10.0 & 61 & AL & $\pi$ & $=20$ & 9.39 & 3.75 & 223.1 & 76.5 & 107.0 & 107.0 & 2.0 & 0.25 & 530 & 917 & 243 & 222 & 692 & 600 & 547 \\
\hline 10.0 & 62 & $A$ & $\boldsymbol{n}$ & 420 & 9.39 & 3.75 & 381.2 & 75.2 & ioe.s & 101.0 & 2.0 & 0.25 & 531 & 19 & 204 & 223 & 694 & 602 & 589 \\
\hline 16.0 & 35 & $\mu$ & 6 & 120 & 2.33 & 3.17 & 107.3 & 57.1 & 16.1 & 171.5 & 1.0 & 0.0 & 584 & 306 & 258 & 245 & 661 & 362 & 534 \\
\hline 10.0 & 16 & $\mathbf{4}$ & 0 & $=20$ & 2.53 & 3.41 & 192.2 & S1. 2 & 17.2 & 171.5 & 0.0 & 0.0 & 505 & 300 & 256 & 201 & 662 & 564 & 515 \\
\hline 10.0 & 37 & $\mathbf{N}$ & v & 20 & 2.52 & 3.47 & 153.2 & 50.2 & 17.2 & 117.5 & 0.0 & 0.0 & 510 & 398 & 258 & 243 & 660 & 572 & 540 \\
\hline 10.0 & 30 & AL & 0 & En & 2.52 & 3.67 & 196.5 & 50.9 & 17. & 117.5 & 1.0 & 0.0 & 513 & 397 & 261 & 243 & 613 & 516 & 543 \\
\hline 10.0 & 19 & $\mathbf{~} \mathbf{L}$ & 0 & $=20$ & 2.52 & 3.41 & 200.0 & 59.7 & 70.7 & 171.5 & $\bullet .0$ & 0.0 & 516 & 100 & 263 & 206 & 675 & 579 & 546 \\
\hline 10.0 & 50 & $\boldsymbol{N}$ & 0 & 120 & 2.52 & 3.97 & 205.2 & 60.0 & 19.7 & 177.5 & 0.6 & 0.0 & 517 & 962 & 264 & 247 & 677 & 501 & 540 \\
\hline 10.0 & 41 & $\boldsymbol{\mu}$ & v & $=20$ & 2.52 & 3.91 & 200.5 & 61.0 & 06.0 & 177.5 & 0.0 & 0.0 & 520 & ces & 265 & 209 & 600 & 504 & 550 \\
\hline 10.0 & 62 & $\mathbf{n}$ & 0 & $=20$ & 2.52 & 3,41 & 214.7 & 61.7 & $0 . .2$ & 177.5 & 2.0 & 0.25 & 501 & 301 & 230 & 216 & 603 & 306 & 516 \\
\hline 10.0 & 43 & $\boldsymbol{u L}$ & v & 1120 & 2.52 & 3.91 & 221.1 & 63.2 & 16.2 & 177.5 & 2.0 & 0.25 & 501 & 303 & 234 & 218 & 602 & sos & 517 \\
\hline 10.0 & 62 & $A$ & v & 120 & 2.52 & 3.41 & 207.3 & 15.2 & 90.2 & 177.5 & 2.0 & 0.29 & 5.0 & 420 & 255 & 214 & 126 & 637 & 615 \\
\hline 10.0 & 63 & 4 & - & 120 & 2.52 & 3.97 & 200.3 & 15.2 & 10.2 & $m .5$ & 2.0 & 0.25 & 543 & 432 & 257 & 236 & 131 & 640 & 610 \\
\hline 10.0 & 64 & $\mathbf{x}$ & v & $=20$ & 2.53 & 3.47 & 292.7 & 16.0 & 99.0 & 177.5 & 2.6 & 0.25 & 580 & 03 & 15* & 236 & 131 & 643 & 619 \\
\hline 10.0 & 65 & $\mathbf{N}$ & $\boldsymbol{0}$ & 120 & 2.52 & 3.47 & 20s. & 16.5 & 98.5 & 177.5 & 2.0 & 0.29 & 546 & 136 & aso & 237 & 133 & 646 & 621 \\
\hline 10.0 & 66 & 4 & v & 120 & 2.53 & 3.47 & 299.5 & 17.2 & 100.1 & 171.5 & 2.0 & 0.25 & 587 & 130 & ass & 230 & 135 & 640 & 623 \\
\hline 10.0 & 67 & as & 0 & $=20$ & 2.52 & 3.91 & 300.6 & 17.2 & 100.1 & 171.5 & 2.0 & 0.25 & 951 & 001 & 261 & 230 & 100 & (5) & 625 \\
\hline 10.0 & 60 & 16 & v & $=20$ & 2.52 & 3.47 & 301.6 & 77.2 & 100.1 & 171.5 & 2.0 & 0.25 & s54 & 945 & 360 & 240 & 184 & 6so & 620 \\
\hline 10.0 & 69 & $\mathbf{A L}$ & - & 020 & 2.50 & 1.61 & 302.7 & 17.2 & 100.1 & 171.5 & 1.0 & -.25 & 557 & 180 & 264 & 241 & 749 & $66:$ & 631 \\
\hline 16.0 & 10 & $A$ & v & 020 & 2.32 & 3.47 & 313.3 & 79.5 & 102.5 & 171.3 & 2.0 & 0.25 & 5s4 & ans & 263 & 241 & 141 & 636 & 629 \\
\hline 10.0 & 11 & $\mu$ & v & 520 & 2.32 & 3.47 & 310.1 & 00.1 & 103.3 & 171.5 & 2.0 & 0.25 & sss & 146 & 263 & 201 & 743 & 657 & 630 \\
\hline 10.0 & 12 & ab & - & $m 20$ & 0.52 & 3.47 & 319.1 & 06.4 & 103.3 & Im.s & 2.0 & 0.25 & 550 & 150 & 263 & 242 & 701 & 662 & 633 \\
\hline 10.0 & 13 & $\boldsymbol{u}$ & 0 & 100 & 2.52 & 3.97 & 320.2 & 6.1 & 103.3 & 111.5 & 2.0 & 0.25 & 361 & 494 & 267 & 294 & 132 & 667 & 635 \\
\hline 10.0 & 10 & $\boldsymbol{\mu L}$ & v & 1020 & 2.52 & 3.67 & 327.1 & 04.7 & 104.1 & 121.5 & 2.0 & 0.25 & 360 & 153 & 266 & 204 & 750 & 665 & 639 \\
\hline
\end{tabular}




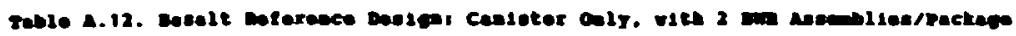

\begin{tabular}{|c|c|c|c|c|c|c|c|c|c|c|c|c|c|c|c|c|c|c|c|}
\hline \multirow[b]{2}{*}{ mas } & \multirow[b]{2}{*}{ crive } & \multicolumn{3}{|c|}{ Eringese } & \multicolumn{2}{|c|}{ 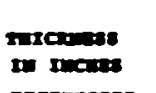 } & \multirow{2}{*}{ 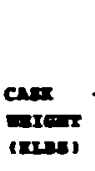 } & & & Incte & & & & $\begin{array}{l}\text { Sher } \\
\text { In }\end{array}$ & 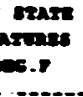 & & & aron & \\
\hline & & & an. & $m$ & can. & S & & ID & $\infty$ & renon & ar. & TII & min & $\operatorname{lng}$ & $\begin{array}{l}\operatorname{ant} \\
\sin \end{array}$ & cons. & rose & $\begin{array}{l}\text { motes } \\
\text { wars }\end{array}$ & $\operatorname{anch}$ \\
\hline 10.0 & 20 & a. & 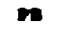 & 100 & 4.62 & 4.25 & 1es.9 & 51.1 & 76.2 & 197.3 & 0.0 & $\bullet .0$ & 362 & 27e & 198 & 199 & e94 & 121 & 911 \\
\hline 10.0 & 29 & $\boldsymbol{N}$ & 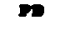 & $=20$ & 0.02 & 0.25 & 190.3 & 32.0 & 71.1 & 197.3 & $\bullet .0$ & $\bullet . \bullet$ & 369 & 200 & 200 & 181 & 697 & 426 & 620 \\
\hline 10.0 & 30 & a. & te & 100 & 4. .2 & 0.25 & 193.0 & 52.5 & 77.5 & 191.3 & 0.0 & 0.0 & 367 & 28 & 201 & 192 & sol & 629 & 423 \\
\hline 10.0 & 31 & a. & $\boldsymbol{P}$ & 200 & 0.02 & 6.25 & 196.1 & 52.5 & 77.5 & 197.3 & 0.0 & $\bullet .0$ & 371 & 20 & 203 & 198 & 507 & 436 & 127 \\
\hline 10.0 & 32 & $\boldsymbol{M}$ & re & 020 & 0.02 & 0.25 & 203. & 54.6 & 79.6 & 197.3 & $\bullet . \bullet$ & $\bullet . \bullet$ & 370 & 208 & 204 & 190 & sos & 633 & 927 \\
\hline 10.0 & 33 & $\boldsymbol{A b}$ & $\mathbf{v}$ & 200 & 0.62 & 0.25 & 206.7 & 55.0 & 16.1 & 191.3 & $\bullet .0$ & $\bullet .0$ & 372 & 208 & 206 & 195 & ses & 630 & 120 \\
\hline 16.0 & 30 & $\boldsymbol{\mu}$ & m & 00 & $\bullet .-2$ & 0.25 & 211.6 & 36.1 & 01.1 & 197.3 & 0.0 & $\bullet . \bullet$ & 370 & 292 & 206 & 196 & ses & 630 & 131 \\
\hline 10.0 & 35 & $\mathbf{A L}$ & 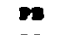 & 100 & 0.02 & 1.25 & 215. & 57.1 & 02.1 & 191.3 & 0.0 & $\bullet . \bullet$ & 376 & 205 & 201 & 197 & 511 & 641 & 633 \\
\hline 10.0 & 36 & $\boldsymbol{A L}$ & 5 & 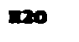 & 0.02 & 0.25 & 221.3 & 50.2 & 03.3 & 197.3 & $\bullet .0$ & $\bullet . \bullet$ & 370 & 296 & 201 & 190 & 512 & 102 & 135 \\
\hline 10.0 & 54 & $\mathbf{A b}$ & re & 20 & 4.02 & 1.25 & 200. & co. 1 & 93.1 & 197.3 & $\bullet . \oplus$ & $\bullet .0$ & 610 & 337 & 228 & 216 & 559 & 196 & 13 \\
\hline 10.0 & 55 & AL & $\boldsymbol{n}$ & 20 & 0.02 & 0.25 & 201.9 & 60.1 & 93.1 & 191.3 & 0.0 & $\bullet . \bullet$ & 611 & 301 & 230 & 211 & s64 & sor & 676 \\
\hline 10.0 & 56 & AL & $\omega$ & 120 & 0.02 & 1.25 & 304.1 & 73.6 & 96.0 & 191.3 & 0.0 & $\bullet . \bullet$ & 110 & 333 & 227 & 215 & 549 & 105 & 470 \\
\hline 10.0 & 57 & al. & ne & 220 & 4.02 & 4.25 & 308.7 & 74.6 & 98.6 & 191.3 & $\bullet$ & 0.0 & 410 & 334 & 220 & 215 & 550 & 106 & 671 \\
\hline 10.0 & se & $\boldsymbol{\mu L}$ & 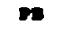 & 20 & 0.02 & 0.25 & 310.0 & 74.0 & 99.0 & 197.3 & 0.6 & $\bullet . \bullet$ & 613 & 337 & 229 & 216 & s5: & 490 & 673 \\
\hline 10.0 & 59 & AL & $\infty$ & 120 & 6.02 & 0.25 & 311.9 & 24.0 & 99. & 191.3 & 0.1 & $\bullet .0$ & 116 & 339 & 231 & 217 & 550 & 498 & 676 \\
\hline 10.0 & 6 & $\mathbf{A}$ & $\boldsymbol{n}$ & 20 & 0.02 & 0.25 & 313.0 & 76.0 & 99.1 & 197.3 & 1.0 & $\bullet .0$ & 10 & 302 & 232 & ats & 561 & 499 & 479 \\
\hline 10.0 & 61 & $\boldsymbol{A}$ & $\omega$ & 20 & 0.02 & 0.25 & 316.3 & 24.5 & 99.5 & 197.3 & $\bullet .6$ & $\bullet . \bullet$ & 420 & 304 & 233 & 213 & 563 & 501 & 180 \\
\hline 10.0 & 62 & As & $\boldsymbol{m}$ & $\mathbf{2 0}$ & 0.02 & -.25 & 320.5 & 75.2 & 106.2 & 191.3 & $\bullet$. & $\bullet .0$ & (21 & 306 & 234 & 220 & sos & $\operatorname{sen}$ & 18 \\
\hline 10.0 & 63 & $\mathbf{N}$ & $m$ & 120 & $\bullet .02$ & 1.25 & 321.5 & 75.2 & 164.2 & 197.3 & $\bullet .0$ & $\bullet .0$ & 420 & 348 & 235 & 221 & 560 & 507 & sen \\
\hline 10.0 & 64 & AL & $\omega$ & 220 & 0.02 & 0.25 & 326.0 & 26.6 & 181.1 & 191.3 & $\bullet . \bullet$ & 0.0 & 124 & 350 & 233 & 222 & s69 & 500 & ies \\
\hline 10.0 & 20 & $\boldsymbol{M L}$ & $m$ & 20 & 9.39 & 3.75 & 1es.9 & 41.0 & 77.1 & 201.5 & $\bullet .6$ & $\bullet . \bullet$ & 300 & 262 & tes & 101 & is6 & 300 & 360 \\
\hline 10.0 & 25 & AL & $\boldsymbol{m}$ & $m 20$ & 9.39 & 3.75 & 109.7 & 00.5 & 71.0 & 201.9 & 0. & 0.0 & 350 & 265 & 190 & 102 & 160 & 305 & 371 \\
\hline 10.6 & 26 & A & $m$ & 020 & 9.38 & 3.75 & 194.2 & 08.1 & 70.7 & 201.5 & $\bullet .0$ & $\bullet .0$ & 353 & 250 & 192 & 184 & 163 & 309 & 370 \\
\hline 10.0 & 27 & $\boldsymbol{A}$ & $m$ & 220 & 9.35 & 3.75 & 190.7 & se.t & 79.6 & 201.5 & 0.0 & $\bullet . \bullet$ & $35 s$ & 270 & 193 & 10s & 166 & 392 & 371 \\
\hline 16.0 & 28 & As & $m$ & $\square 20$ & 9.38 & 3.75 & 202.7 & 51.1 & 00.1 & 201.5 & $\bullet .0$ & 0.0 & 350 & 273 & 198 & 106 & 670 & 296 & 200 \\
\hline 10.0 & 25 & $\boldsymbol{A L}$ & $m$ & $\square 20$ & 9.39 & 3.75 & 207.3 & 52.0 & 01.2 & 201.5 & $\bullet .0$ & 0.0 & 360 & 276 & 196 & 101 & 673 & 399 & 303 \\
\hline 10.0 & 30 & A & $\omega$ & 120 & 9.35 & 3.75 & 210.1 & 52.5 & 01.7 & 201.5 & $\bullet .0$ & 0.0 & 363 & 275 & 197 & 100 & 677 & 104 & 306 \\
\hline 10.0 & 31 & AL & $\mathbf{m}$ & 120 & 9.30 & 3.75 & 211.2 & 52.5 & 01.7 & 201.5 & 0.0 & 0.0 & 366 & 203 & ise & 190 & 102 & 10 & 390 \\
\hline 10.0 & 32 & $\mathbf{A}$ & $m$ & 120 & 9.38 & 3.75 & 220.5 & 50.6 & 83.1 & 261.5 & 0.0 & $\bullet .0$ & 366 & 203 & 200 & 190 & 101 & cos & 390 \\
\hline 16.0 & 46 & AL & $m$ & 120 & 9.39 & 3.75 & 270.2 & 68.0 & 90.1 & 261.5 & 0.0 & 0.0 & 392 & 313 & 215 & 203 & 515 & 607 & ea! \\
\hline 14.0 & 97 & $\boldsymbol{A}$ & $m$ & 120 & 9.39 & 3.75 & 203.2 & 65.7 & Is.t & 201.5 & 0.0 & $\bullet . \bullet$ & 393 & 310 & 215 & 208 & 516 & ase & 122 \\
\hline 16.0 & 40 & $\boldsymbol{A L}$ & $\omega$ & 620 & 9.39 & 3.75 & 207.1 & 66.6 & 95.6 & 201.5 & 0.0 & $\bullet . \bullet$ & 395 & 316 & 216 & 205 & 510 & os1 & 124 \\
\hline 16.0 & 49 & $\boldsymbol{\mu}$ & $n$ & 120 & 9.39 & 3.75 & 209.3 & 66.6 & 95.0 & 201.5 & 0.0 & $\bullet .0$ & 396 & 319 & 210 & 206 & 322 & ess & .21 \\
\hline 10.0 & 50 & As & $m$ & 120 & 9.39 & 3.75 & 294.0 & 61.6 & 96.7 & 201.5 & 0.0 & 0.0 & 399 & 320 & 219 & 207 & 523 & 157 & 120 \\
\hline 18.0 & 31 & AL & $m$ & 120 & 9.39 & 3.75 & 290.0 & 66.1 & 97.4 & 201.5 & 0.0 & 0.0 & 100 & 322 & 219 & 200 & sas & Ass & 130 \\
\hline 10.0 & 32 & AL & ne & 120 & 9.39 & 3.75 & 289.0 & 60.1 & 91.4 & 201.5 & 0.0 & $\bullet .0$ & 103 & 325 & 221 & 209 & 520 & 468 & 633 \\
\hline 10.0 & 33 & $\mathbf{A}$ & $m$ & $\square 20$ & 9.39 & 3.75 & 300.1 & 60.1 & 91. & 201.5 & 0.6 & 0.0 & 104 & 320 & 222 & 210 & 533 & 160 & 136 \\
\hline 16.0 & 54 & AL & $n$ & $=20$ & 9.38 & 3.75 & 301.2 & 6.1 & 97.1 & 261.5 & 0.6 & 0.0 & ses & 332 & 220 & 211 & 537 & 613 & 19 \\
\hline 10.0 & 35 & $\mathbf{A}$ & $n$ & $\square 20$ & 9.39 & 3.73 & 302.3 & 60.1 & 97.4 & 261.5 & 0.0 & 0.0 & $\$ 11$ & 335 & 225 & 212 & 581 & 617 & 101 \\
\hline 10.0 & 36 & AL & $n$ & 120 & 9.39 & 3.75 & 325.5 & 13.0 & 102.2 & 201.5 & 0.0 & 0.0 & ons & 321 & 223 & 210 & 529 & 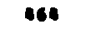 & 136 \\
\hline 10.0 & 32 & AL & 0 & 120 & 2.52 & 3.01 & 107.7 & 58.6 & 73.5 & 191.2 & 0.0 & $\bullet .0$ & 370 & 202 & 209 & 200 & 510 & 4a: & 150 \\
\hline 10.0 & 33 & Al & 0 & 120 & 2.52 & 3.91 & 193.2 & 55.0 & 10.0 & 191.2 & 0.6 & 0.0 & 375 & 293 & 210 & 201 & 515 & as & 451 \\
\hline 10.0 & 34 & $\boldsymbol{\mu}$ & 0 & 120 & 2.52 & 3.07 & 196.0 & 56.3 & 75.3 & 191.2 & 0.0 & 0.0 & 370 & 296 & 212 & 202 & 318 & ens & esa \\
\hline 10.0 & 35 & As & 0 & 120 & 2.52 & 3.01 & 200.1 & $\$ 7.1$ & 26.1 & 191.2 & 0.0 & 0.0 & 300 & 205 & 213 & 203 & 521 & 152 & 456 \\
\hline 10.0 & 36 & AL & 0 & $\mathbf{n 2 0}$ & 2.52 & 3,01 & 205.0 & se.2 & 11.2 & 191.2 & 0.0 & $\bullet .0$ & 301 & 300 & 210 & 208 & 321 & 953 & 450 \\
\hline 10.0 & 37 & A. & 0 & 120 & 2.32 & 3.67 & 206.5 & 58.2 & 77.2 & 191.2 & 0.0 & 0.1 & 308 & 304 & 216 & 205 & 527 & ess & 161 \\
\hline 16.0 & 30 & $\mathbf{A L}$ & 0 & $\mathbf{m 2 0}$ & 2.52 & 3.01 & 210.0 & se. & 11.9 & 191.2 & 0.0 & 0.0 & 301 & 306 & 211 & 207 & 530 & 162 & 464 \\
\hline 10.6 & 39 & a & 0 & 120 & 2.52 & 3.67 & 214.1 & 59.7 & 10.7 & 191.2 & 0.0 & 6.0 & 306 & 300 & d1e & 207 & 532 & 960 & 166 \\
\hline 10.0 & 40 & $\boldsymbol{A}$ & 0 & 120 & 2.52 & 3.67 & 219.2 & 60.0 & 19.7 & 191.2 & 0.0 & 0.0 & 390 & 310 & 219 & 200 & 533 & 165 & 167 \\
\hline 10.0 & 41 & AL & v & $=20$ & 2.32 & 3.97 & 222.7 & 61.6 & 00.1 & 191.2 & 0.0 & 0.0 & 391 & 312 & 220 & 285 & 535 & 60 & 69 \\
\hline 10.0 & 93 & $\boldsymbol{A L}$ & $\mathbf{v}$ & ma & 2.52 & 3.07 & 264.2 & 68.1 & 07.1 & 191.2 & $\bullet .0$ & 0.0 & 480 & 345 & 237 & 224 & 573 & 315 & 500 \\
\hline 10.0 & 56 & AL & $\nabla$ & $m 20$ & 2.52 & 3.91 & 205.0 & 13.0 & 91.0 & 191.2 & 0.0 & 0.0 & 413 & 331 & 233 & 221 & $5 s 0$ & 695 & 192 \\
\hline 10.0 & 37 & AL & 0 & 120 & 2.52 & 3.91 & 290.9 & 18.0 & 93.0 & 191.2 & 0.0 & 0.0 & 410 & 330 & $: 10$ & $\operatorname{saz}$ & 530 & ies & (9) \\
\hline 10.0 & 50 & AL & 0 & $m 20$ & 2.52 & 3.48 & 292.0 & 10.0 & 93.0 & 191.2 & 0.0 & $\bullet .0$ & 117 & 301 & 235 & 223 & 562 & 500 & 996 \\
\hline 10.0 & 50 & AL & v & 120 & 2.52 & 3.47 & 293.1 & 18.0 & 93.0 & 191,2 & $\bullet .0$ & $\bullet .0$ & 119 & 380 & 237 & 224 & 566 & 504 & 498 \\
\hline 10.0 & 6 & $\boldsymbol{M}$ & 0 & 120 & 2.52 & 3.91 & 294.2 & 10.0 & 93.0 & 191.2 & 0.0 & 0.0 & 122 & 301 & 230 & 225 & $\$ 70$ & 500 & 501 \\
\hline 10.0 & 61 & AL & 0 & $m 20$ & 2.52 & 3.91 & 207.4 & 14.5 & 93.5 & 191.2 & 0.0 & 0.0 & 624 & 309 & 239 & 226 & 572 & 511 & 503 \\
\hline 10.0 & 62 & ML & 0 & 020 & 2.52 & 3.97 & 301.0 & 15.2 & 94.2 & 191.2 & 0.0 & 0.0 & 025 & 350 & 200 & 227 & 574 & 512 & 500 \\
\hline 10.0 & 63 & $\boldsymbol{A}$ & 0 & 120 & 2.52 & 3.47 & 3ea.s & 15.2 & 94.2 & 101.2 & 0.0 & 6.1 & 927 & 333 & $2 \div 1$ & 220 & 571 & 316 & 507 \\
\hline 10.0 & 64 & $\mathbf{A}$ & 0 & 120 & 2.32 & 3.91 & 367.2 & 16.0 & 95.0 & 191.2 & 0.0 & 0.0 & 220 & 334 & 242 & 229 & 570 & 517 & 594 \\
\hline 10.0 & 65 & $\mu$ & 0 & 120 & 2.32 & 3.47 & 310.5 & 16.5 & 95.3 & 191.2 & 0.0 & $\bullet$ & $\$ 30$ & 3ss & 243 & 220 & 500 & 519 & 56, \\
\hline 10.0 & 66 & AL & 0 & $m 20$ & 2.52 & 3.01 & 319.3 & 11.2 & 16.1 & 191.2 & 0.0 & 0.0 & 631 & 397 & 244 & 230 & sor & 321 & 511 \\
\hline 10.0 & 67 & AL & v & $\mathbf{9 2 0}$ & 2.52 & 3.67 & 315.4 & 11.2 & 96.1 & 191.2 & 0.0 & 0.0 & 433 & 360 & 245 & 231 & sos & s2s & 513 \\
\hline 10.0 & 6 & AL & 0 & 120 & 2.52 & 3.01 & 316.5 & 17.2 & 96.1 & 191.2 & 0.0 & 0.0 & 436 & 363 & 296 & 232 & sos & 528 & 516 \\
\hline 10.0 & 69 & AL & 0 & 110 & 2.52 & 1.91 & 317.6 & 11.2 & 96.1 & 191.2 & 0.0 & 0.0 & 0 & 365 & 240 & 236 & 502 & 533 & 510 \\
\hline 10.0 & 10 & $A$ & $v$ & 120 & 2.52 & 3.47 & 320.9 & 19.5 & 90.5 & 111.2 & 0.0 & 0.0 & 436 & 361 & 247 & 231 & 301 & 520 & 516 \\
\hline
\end{tabular}




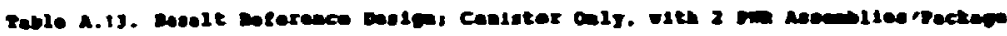

\begin{tabular}{|c|c|c|c|c|c|c|c|c|c|c|c|c|c|c|c|c|c|c|c|}
\hline \multirow[b]{2}{*}{101} & \multirow{2}{*}{ conse } & \multicolumn{3}{|c|}{ curaturs } & \multicolumn{2}{|c|}{ 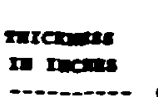 } & \multirow{2}{*}{$\begin{array}{l}\cos x \\
\text { (nemes) }\end{array}$} & \multirow{2}{*}{ ID } & \multicolumn{4}{|c|}{ In yeres } & \multicolumn{4}{|c|}{ 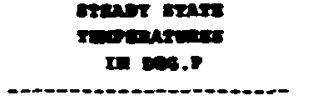 } & \multicolumn{3}{|c|}{ 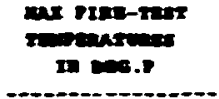 } \\
\hline & & twan & $\operatorname{enc}$ & $\sin$ & ans. & ins & & & $\infty$ & $x=1$ & rw. & trin. & max & nat & cons & exp. & 10 & ruse & and \\
\hline $10 . \bullet$ & 17 & $\boldsymbol{\mu}$ & se & $=20$ & $\bullet .02$ & 0.35 & 163.5 & 52.8 & 17.0 & 103.5 & $\bullet . \bullet$ & 0.0 & 565 & 391 & 250 & 234 & 116 & 565 & $\sin$ \\
\hline 10.0 & 10 & as & $\boldsymbol{n}$ & $m 0$ & 4.02 & 0.25 & 190.5 & 53.3 & $7 e .4$ & 103.5 & 6.0 & $\bullet .0$ & sie & 198 & 254 & 237 & 123 & 378 & 523 \\
\hline 10.0 & 19 & ar & $\boldsymbol{n}$ & $=20$ & $\bullet .02$ & 0.25 & 192.6 & 53.3 & 10.0 & 103.5 & $\bullet . \bullet$ & 0.0 & 500 & 110 & 258 & 201 & 136 & s9o & 512 \\
\hline $16 . \bullet$ & 20 & $\boldsymbol{N}$ & $\omega$ & 720 & 0.02 & 0.25 & 201.2 & 55.2 & e. 3 & 103.5 & $\bullet$ & 6.0 & sen & 413 & 262 & 244 & 739 & 598 & 537 \\
\hline 16.0 & 21 & ns & $\mathbf{n}$ & 20 & 0.02 & 0.25 & 207.9 & 56.5 & $0 t .6$ & 103.5 & $\bullet . \bullet$ & 0.0 & ses & 021 & 265 & 241 & tas & 61 & $\sin 2$ \\
\hline 10.0 & 22 & $\alpha$ & $\mathbf{n}$ & $\infty 20$ & $\bullet .02$ & 0.25 & 217.1 & 50.5 & 03.5 & 103.5 & 0.0 & 0.6 & 592 & tas & 260 & 245 & 197 & 60 & 506 \\
\hline 10.0 & 32 & As & $\omega$ & 20 & 0.02 & 4.25 & 205.4 & 69.5 & 90.5 & 103.5 & 2.0 & 0.25 & 612 & ise & 250 & 230 & 795 & 661 & $\operatorname{ces}$ \\
\hline 10.0 & 33 & As & $\omega$ & $\mathbf{m 2 0}$ & 0.02 & 0.25 & 296.1 & 11.1 & 100.1 & 103.5 & 2.0 & 0.25 & 614 & 452 & 25) & ass & 757 & 663 & 611 \\
\hline 10.0 & 34 & As & $n$ & 720 & 9.02 & 4.25 & 29e.t & 78.7 & 100.7 & 103.5 & 2.0 & 0.25 & 619 & 4se & 202 & 231 & 103 & 670 & 616 \\
\hline 16.0 & 35 & $\boldsymbol{N}$ & 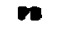 & $=20$ & 0.02 & 0.25 & 105.2 & 12.7 & 161.0 & 103.5 & 2.0 & 0.23 & 622 & 462 & 264 & 238 & 006 & 675 & 6190 \\
\hline 10.0 & 36 & $\boldsymbol{x}$ & $\omega$ & 120 & 4.02 & 0.25 & 313.5 & 74.2 & 103.2 & 103.5 & 2.6 & 0.25 & 624 & 463 & 265 & 240 & see & 677 & 6210 \\
\hline 10.0 & 37 & $\boldsymbol{N}$ & $\boldsymbol{n}$ & 720 & 0.62 & 0.25 & 315.4 & 10.2 & 103.2 & 103.5 & 2.0 & 6.23 & 631 & $\bullet 12$ & 260 & 2912 & 116 & $6 e 7$ & 6270 \\
\hline 18.6 & is & as & n & 120 & 9.39 & 3.75 & 183.7 & 10.7 & 71.5 & 107.0 & 0.0 & 0.0 & 540 & נro & 236 & 222 & 677 & 521 & 465 \\
\hline 10.6 & 16 & $\boldsymbol{N}$ & $n$ & 120 & 9.38 & 3.75 & 191.2 & 56.2 & 79.5 & 107.0 & $\bullet$ & 0.6 & 950 & 377 & 200 & 225 & 69 & 529 & 912 \\
\hline 10.0 & 11 & as & $m$ & $\mathbf{n 2 0}$ & 9.39 & 3.75 & 198.5 & 51.9 & 81.2 & 101.6 & 0.0 & 0.0 & 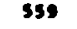 & 300 & 243 & 220 & 690 & 537 & 470 \\
\hline 16.0 & 10 & 16 & $n$ & 120 & 9.31 & 3.73 & 206.0 & 53.3 & 02.6 & 187.0 & 0.0 & 0. & 564 & 391 & 247 & 231 & 697 & ses & 16 \\
\hline 10.0 & 18 & $\boldsymbol{\Lambda x}$ & $n$ & 20 & 9.38 & 3.75 & 200.9 & 53.1 & 22.6 & 101.0 & $\bullet .0$ & $\bullet .0$ & 579 & 902 & $2 s 2$ & 235 & 70 & 568 & 590 \\
\hline 10.0 & 30 & as & $n$ & 720 & 9.39 & 3.75 & 217.9 & 35.2 & 06.5 & 181.9 & 0.0 & $\bullet .6$ & 577 & $\$ 67$ & 2ss & 231 & 713 & 365 & 496 \\
\hline 16.0 & 29 & AL & $n$ & nov & 9.39 & 3.75 & 205.1 & 64.2 & 99.5 & 167.1 & 2.0 & 0.25 & 596 & 429 & 246 & 224 & 737 & 617 & 596 \\
\hline 10.0 & 30 & as & $n$ & 120 & 5.38 & 3.75 & 208.7 & 66.6 & 100.1 & 197.4 & 3.0 & 0.23 & 601 & 635 & 240 & 226 & 763 & 625 & 560 \\
\hline 10.0 & 31 & $\boldsymbol{M}$ & $n$ & 120 & 9.38 & 3.75 & 291.0 & 66.6 & 186.1 & 187.8 & 2.0 & 0.25 & 600 & 140 & 252 & 228 & 712 & 616 & 567 \\
\hline 10.0 & 32 & A & $\boldsymbol{r}$ & $\mathrm{m20}$ & $\$ .31$ & 3.75 & 305.2 & 69.5 & 102.0 & 107.8 & 2.6 & 0.25 & 606 & 643 & 252 & 228 & 710 & 633 & 567 \\
\hline 10.0 & 33 & $\mathbf{A b}$ & $n$ & mo & 9.30 & 3.75 & 314.0 & 21.1 & 104.3 & 197.6 & 2.0 & 0.25 & 608 & 445 & 253 & 230 & 712 & 636 & site \\
\hline 16.0 & 36 & $\mathbf{x}$ & $n$ & 120 & 5.39 & 3.75 & 316.9 & 71.7 & tes.e & 187.8 & 2.0 & 0.25 & 613 & AS1 & 296 & 212 & 77 & 603 & 574 \\
\hline 10.0 & 18 & As & $\nabla$ & 120 & 2.52 & 3.41 & 101.0 & 53.3 & 76.3 & 177.5 & 2.0 & 0.25 & 561 & 389 & 235 & 218 & ins & 42 & 502 \\
\hline 10.0 & 20 & $\mathbf{A}$ & 0 & $=20$ & 2.52 & 3.47 & 190.2 & 55.2 & 76.2 & 117.5 & 2.0 & 0.25 & 567 & 393 & 237 & 219 & 151 & 603 & 506 \\
\hline 10.0 & 21 & Ab & 0 & $\pi 20$ & 2.52 & 3.41 & 196.0 & 56.5 & 78.5 & 178.5 & 2.0 & 0.25 & 571 & 195 & 240 & 221 & 757 & 612 & ser \\
\hline 10.6 & 22 & as & 0 & 120 & 2.52 & 3.07 & 205.0 & 58.5 & 01.5 & 177.5 & 2.1 & 0.25 & 574 & 162 & 201 & 223 & 750 & 613 & 594 \\
\hline 10.0 & 23 & AL & $\mathbf{v}$ & $\mathbf{1 2 0}$ & 2.52 & 3.01 & 212.3 & 39.7 & 02.1 & 177.5 & 2.0 & 0.25 & 580 & 416 & 244 & 225 & 163 & 620 & 590 \\
\hline 16.0 & 24 & A6 & 0 & $\mathbf{m} 0$ & 2.52 & 3.47 & 216.4 & 66 & 03.1 & 177.5 & 2.0 & 0.25 & 583 & 113 & 247 & 227 & 769 & 626 & 603 \\
\hline 10. & 35 & A6 & $\mathbf{0}$ & $\pi 20$ & 2.52 & 3.48 & 206.6 & 72.7 & 05.1 & 117.5 & 2.6 & 0.29 & 625 & ocs & 271 & 247 & 615 & $\cos$ & 645 \\
\hline 10.0 & 36 & AL & $\mathbf{v}$ & $\mathbf{m 2 0}$ & 2.52 & 3.47 & 294.5 & 74.2 & 91.2 & 177.5 & 2.0 & 0.25 & 637 & 460 & 272 & 240 & 017 & 607 & $\mathbf{s e c}$ \\
\hline 10.0 & 37 & $\mathbf{A L}$ & $\mathbf{0}$ & $=20$ & 2.52 & 3.47 & 296.6 & 74.2 & 91.2 & 178.5 & 2.6 & 0.25 & 633 & 475 & 275 & 250 & 126 & 697 & 653 \\
\hline 10.0 & 30 & at & $\mathbf{0}$ & 120 & 2.52 & 3.67 & 303.1 & 75.0 & 100.0 & 177.5 & 3,6 & 0.25 & 632 & 49 & 265 & 244 & 131 & 703 & 666 \\
\hline 10.0 & 39 & As & 0 & 120 & 2.52 & 3.47 & 309.5 & 76.1 & 101.0 & 177.5 & 3.0 & 0.25 & 635 & 47 & 271 & 245 & 634 & 707 & 66 \\
\hline 10.0 & 40 & $\mathbf{N}$ & 0 & \pm 20 & 2.52 & 3.41 & 317.2 & 17.6 & 102.4 & 111.5 & 3.0 & 0.25 & 631 & 400 & 272 & 247 & 136 & 100 & 670 \\
\hline
\end{tabular}




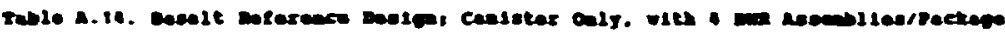

\begin{tabular}{|c|c|c|c|c|c|c|c|c|c|c|c|c|c|c|c|c|c|c|c|}
\hline \multirow[b]{2}{*}{$\max$} & \multirow[b]{2}{*}{ co. } & \multicolumn{3}{|c|}{ armive } & \multicolumn{2}{|c|}{ In } & \multirow{2}{*}{$\begin{array}{l}\text { cant } \\
\text { (nexes) }\end{array}$} & \multicolumn{5}{|c|}{ In nestom } & \multicolumn{4}{|c|}{ 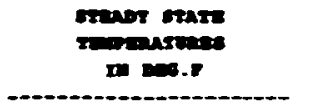 } & \multicolumn{3}{|c|}{ 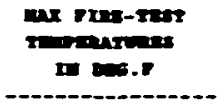 } \\
\hline & & & סוx. & שי, & ס्र. & Wes & & 18 & $\infty$ & $x=\operatorname{sen}$ & m. & tw. & Int & $\operatorname{mix}_{\operatorname{mix}}$ & תוx & $\begin{array}{l}\text { CNR } \\
\text { tan. }\end{array}$ & in & $\begin{array}{l}\max \\
\max \end{array}$ & $\cos _{\cos }$ \\
\hline 10.0 & 16 & N & e & 120 & 0.02 & 0.25 & 101.6 & 50.2 & 75.3 & 198.1 & $\bullet$. & $\bullet .0$ & ate & 297 & 267 & 197 & 555 & 143 & 436 \\
\hline 10.6 & 17 & $\mathbf{N}$ & $\boldsymbol{m}$ & $\infty$ & 0.02 & 1.25 & 195.8 & 51.8 & 71.0 & 198.3 & $\bullet . \bullet$ & $\bullet . \bullet$ & 922 & Je2 & 268 & 199 & 559 & 150 & ase \\
\hline 10.๑ & 10 & $\boldsymbol{N}$ & $\omega$ & $\infty$ & 0.02 & 0.25 & 203.3 & 53.3 & 70. & 197.3 & -... & $\bullet . \bullet$ & 126 & 307 & 212 & 201 & 564 & 160 & 445 \\
\hline 10. & 15 & $\mathbf{x}$ & $m$ & $\infty$ & 4.02 & 9.25 & 205.5 & 53.3 & 70.4 & 197.3 & 0. & $\bullet . \bullet$ & 433 & 315 & 216 & 294 & 575 & (1) & 452 \\
\hline $10 . \bullet$ & 20 & $\mathbf{N}$ & $\omega$ & $\infty$ & 0.02 & 0.25 & 210.7 & 53.2 & ee. 3 & 197.3 & 0.0 & $\bullet$ & 936 & 310 & 217 & 206 & 317 & ats & iss \\
\hline 1ै. & 21 & $\boldsymbol{N}$ & $\boldsymbol{m}$ & $\infty$ & 0.02 & 1.25 & 221.8 & 56.5 & 01.6 & 197.3 & $\bullet . \bullet$ & $\bullet$. & 940 & 323 & 220 & 200 & 582 & 401 & 96 \\
\hline 10.0 & 30 & $\boldsymbol{N}$ & $\boldsymbol{\omega}$ & $\infty$ & 0.02 & $\$ .25$ & 202.9 & 68.0 & 91.9 & 198.3 & $\bullet . \bullet$ & $\bullet . \bullet$ & 170 & 359 & 210 & 224 & 610 & 524 & נ9 \\
\hline 16.0 & 31 & $\mathbf{x}$ & n & 100 & 0.02 & 1.25 & 205.1 & 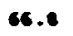 & 91.9 & (5) . & $\bullet$. & 6 & 976 & 365 & 241 & 226 & 626 & 533 & 990 \\
\hline 10.0 & 32 & $x$ & $\omega$ & $\infty$ & 0.02 & ๑.25 & 298.7 & 69.5 & 94..3 & 197.3 & 0.0 & $\bullet$ & ins & 360 & 201 & 221 & 622 & 528 & 490 \\
\hline 16. & 33 & $\boldsymbol{M}$ & $\omega$ & $\infty$ & 0.02 & 4.25 & 301.6 & 11.1 & 96.1 & 197.1 & $\bullet . \bullet$ & $\bullet$ & 176 & 366 & 203 & 228 & 620 & 531 & 500 \\
\hline 18.0 & 34 & $\boldsymbol{N}$ & $n$ & 120 & 0.02 & 9.25 & 313.5 & 71.7 & 96.7 & 198.3 & $\bullet . \bullet$ & ๑. & 400 & 370 & 245 & 230 & 628 & 536 & soe \\
\hline 10.0 & 33 & $\boldsymbol{\Lambda}$ & $\omega$ & $=20$ & 0.02 & 4.23 & 319.3 & 72.7 & 1. & 197.3 & $\bullet .0$ & $\bullet$ & 103 & 313 & 296 & 231 & 632 & 510 & 506 \\
\hline 10.0 & $\cdot$ & $\boldsymbol{N}$ & $\boldsymbol{r}$ & $\infty$ & 9.38 & 3.75 & toe. . & 01.2 & 76.5 & 201.5 & $\bullet . \bullet$ & $\bullet . \bullet$ & ess & 202 & 197 & 100 & sie & 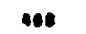 & 347 \\
\hline 10.0 & 13 & $\mathbf{n}$ & $n$ & 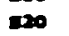 & 9.39 & 3.75 & 196.0 & 0.1 & ו. & 201.5 & $\bullet$ & $\bullet$ & 10 & 287 & 200 & 151 & 325 & $\$ 16$ & 353 \\
\hline 16.6 & 16 & $\boldsymbol{N}$ & $\boldsymbol{m}$ & $\infty$ & 5.38 & 3.75 & 204.2 & 50.2 & 78.5 & 201.5 & $\bullet . \bullet$ & $\bullet . \bullet$ & 114 & 282 & 203 & 193 & 530 & 122 & 390 \\
\hline 10.0 & 11 & $\boldsymbol{x}$ & $m$ & $\infty$ & ง.30 & 3.75 & 212.8 & si.t & 1.2 & 201.5 & $\bullet . \bullet$ & •.๑ & 110 & 296 & 205 & igs & 530 & 128 & 103 \\
\hline 10. & 10 & $\boldsymbol{N}$ & $r$ & 100 & 9 & 3.75 & 220.6 & -3.3 & 12.6 & 201.5 & 0 & $\bullet$ & 922 & 3et & 200 & 191 & sete & 434 & 460 \\
\hline 10.0 & 21 & $\mathbf{x}$ & 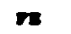 & $=0$ & 5.30 & 3.75 & 280.6 & 64.1 & 93.0 & 201.5 & $\bullet . \bullet$ & $\bullet . \bullet$ & ase & 30 & 227 & 214 & $\operatorname{sen}$ & 484 & 196 \\
\hline 10.0 & 28 & ns & $\boldsymbol{n}$ & 120 & 9.31 & 3.75 & 291.0 & 65.1 & 1. & 201.5 & $\bullet . \bullet$ & $\bullet . \bullet$ & ase & 389 & 228 & 216 & 306 & aes & 450 \\
\hline 18.0 & 28 & ax & $n$ & $=20$ & 9.31 & 3.75 & 291.2 & 66.2 & 95.5 & 201.5 & ๑. & $\bullet . \bullet$ & 461 & 308 & 231 & 217 & 390 & 493 & 453 \\
\hline 10.0 & 10 & $\mathbf{n}$ & $\mathbf{n}$ & $\infty$ & 9.31 & 1.75 & 303.0 & 66. & 96.1 & 201.5 & $\bullet . \bullet$ & $\bullet . \bullet$ & ecs & 352 & 233 & 211 & ses & 500 & ase \\
\hline 18.0 & 31 & $\mathbf{n}$ & $n$ & 120 & 9.38 & 3.75 & 305.2 & 66.0 & 96.1 & 201.5 & $\bullet . \bullet$ & $\bullet . \bullet$ & 470 & Jse & 236 & 222 & 603 & 500 & 963 \\
\hline 10.0 & 12 & $\boldsymbol{\mu}$ & $\boldsymbol{n}$ & 120 & 5.18 & 3.75 & 319.3 & 69.5 & 90.0 & 201.5 & $\bullet . \bullet$ & $\bullet . \bullet$ & 469 & 350 & 236 & 222 & 600 & 506 & 163 \\
\hline 16.0 & 10 & $\boldsymbol{M}$ & - & 120 & 2.32 & 3.41 & 160.3 & 53.3 & 72.3 & 191.2 & $\bullet . \bullet$ & $\bullet . \bullet$ & 40 & 311 & 216 & 208 & 575 & 473 & 169 \\
\hline 10.0 & 18 & $\boldsymbol{\mu L}$ & - & 100 & 2.52 & 3.97 & 190.5 & 53.3 & 12.3 & 191.2 & $\bullet .0$ & $\bullet . \bullet$ & +37 & 320 & 222 & 211 & sec & ins & 11 \\
\hline 10.0 & 20 & $\mu$ & v & 120 & 2.32 & 3.41 & 198.3 & 35.2 & 10.2 & 191.2 & $\bullet .0$ & $\bullet .0$ & 196 & 323 & 224 & 213 & sea & 417 & 900 \\
\hline 10.0 & 21 & $\boldsymbol{M}$ & - & 120 & 2.52 & 3.91 & 206.2 & 96.5 & 75.3 & 191.2 & 1.0 & $\bullet .6$ & 494 & 321 & 226 & 215 & $s 92$ & 192 & ese \\
\hline 10.0 & 22 & $\boldsymbol{N}$ & v & 120 & 2.32 & 3.47 & 215.7 & se.s & 17.5 & 191.2 & 1.0 & $\bullet$. & 196 & 330 & 228 & 216 & S93 & 494 & 106 \\
\hline 10.6 & 23 & $\boldsymbol{N}$ & $\nabla$ & $=20$ & 2.32 & 3.47 & 222.5 & 59.7 & 10.7 & 181.2 & 0.0 & $\bullet . \bullet$ & 940 & 334 & 230 & 210 & 597 & 498 & 480 \\
\hline 10.0 & 33 & 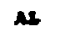 & - & 120 & 2.52 & 1.01 & 209.3 & ו. ו' & se. & 191.2 & $\bullet$. & $\bullet . \bullet$ & 106 & 31 & 250 & 235 & 63) & st: & 323 \\
\hline 10.0 & 34 & $\boldsymbol{N}$ & 0 & 020 & 2.52 & 3.41 & 284.1 & 11.7 & ⿻日. 7 & 181.2 & 0.0 & $\bullet \bullet$ & 104 & 375 & 252 & 237 & 630 & 546 & 527 \\
\hline 10.0 & 13 & $\boldsymbol{N}$ & 0 & 120 & 2.53 & 3.91 & 300.7 & 12.7 & $\$ 1.7$ & 191.2 & $\bullet .0$ & e.t & 106 & 370 & 253 & 239 & 691 & 350 & 530 \\
\hline 10.0 & 36 & At & - & 120 & 2.52 & 1.41 & 308.1 & 10.2 & 93.2 & 191.2 & 6 & -. & ase & 100 & 255 & 280 & 642 & 552 & 532 \\
\hline 10.0 & 37 & 14 & . & 1020 & 2.52 & 3.01 & 311.3 & 14.2 & $\$ 3.2$ & 191.2 & 6.0 & $\bullet .0$ & 483 & 306 & 251 & 242 & 699 & 360 & 536 \\
\hline 10.0 & 10 & $\boldsymbol{M L}$ & 0 & 120 & 2.32 & 3.17 & נו11.0 & 15.0 & 94.0 & 191.2 & 6. & 0.0 & 196 & ses & 259 & 240 & 65) & 560 & 534 \\
\hline
\end{tabular}




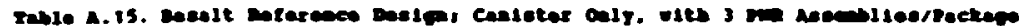

\begin{tabular}{|c|c|c|c|c|c|c|c|c|c|c|c|c|c|c|c|c|c|c|c|}
\hline \multirow[b]{2}{*}{$\min$} & \multirow[b]{2}{*}{ con. } & \multicolumn{3}{|c|}{ masteraes } & \multicolumn{2}{|c|}{ Inodinges } & \multirow{2}{*}{$\begin{array}{l}\text { can: } \\
\text { anes } \\
\text { ctins: }\end{array}$} & \multicolumn{5}{|c|}{ In } & \multicolumn{4}{|c|}{ 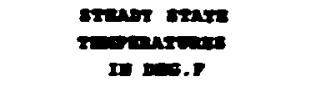 } & \multicolumn{3}{|c|}{ 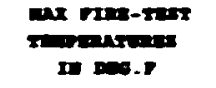 } \\
\hline & & & in. & $\tan _{\cos }$ & ent. & קוd & & ID & $\infty$ & Him & rin & 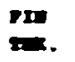 & in & Inser & ond & exr & $\begin{array}{l}\text { var } \\
\text { ox }\end{array}$ & $\begin{array}{l}\text { Ind } \\
\text { nax }\end{array}$ & סגרe \\
\hline 10.0 & 12 & as & $\mathbf{m}$ & 000 & 0.02 & 4.25 & 186.3 & 52.5 & 77.5 & 103.3 & $\bullet . \bullet$ & $\bullet .0$ & 610 & 401 & 255 & 230 & 763 & see & sas \\
\hline 16.0 & 13 & $\boldsymbol{N}$ & $\mathbf{m}$ & ס20 & $\bullet .02$ & 1.25 & 197.3 & 54.0 & 79.0 & 103.5 & $\bullet .0$ & 0.0 & 610 & 011 & 268 & 202 & 711 & 590 & 533 \\
\hline 18. & ie & $\mathbf{A L}$ & $\boldsymbol{m}$ & $\mathbf{E}$ & $\bullet .02$ & 4.25 & 200.2 & 56.9 & 62.0 & 103.5 & $\bullet . \bullet$ & $\bullet$ & 625 & 019 & 265 & 206 & mo & 598 & 541 \\
\hline 10.0 & 15 & as & $\boldsymbol{\omega}$ & 200 & $\bullet .02$ & 4.25 & 211.6 & 50.7 & 63.7 & 103.5 & $\bullet$ & $\bullet . \bullet$ & 632 & 929 & 270 & 250 & 707 & 611 & 549 \\
\hline 16.0 & 22 & $\mathbf{A}$ & De & 100 & 9.02 & 4.25 & 290.4 & 70.6 & 99.7 & 183.5 & 2.0 & 0.25 & 632 & 454 & 260 & 236 & (3) & 666 & 612 \\
\hline 10.0 & 23 & $\boldsymbol{N}$ & $\mathbf{m}$ & $\infty x$ & $\bullet .02$ & 4.25 & 299.7 & 72.1 & 101.2 & 183.5 & 2.0 & 0.25 & 657 & 861 & 263 & 230 & 039 & 678 & 610 \\
\hline 10.6 & 20 & $\mathbf{A L}$ & 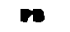 & $=20$ & 9.02 & 4.25 & 300.9 & 73.5 & 102.5 & 103.5 & 2.0 & 0.25 & 663 & 967 & 266 & 241 & 096 & 602 & 6230 \\
\hline 10.0 & 25 & $\boldsymbol{N}$ & $\boldsymbol{m}$ & $\infty$ & 0.02 & 0.25 & 316.2 & 79.6 & 103.7 & 103.5 & 2.0 & 0.25 & 668 & 475 & 268 & 283 & 053 & 68 & 6290 \\
\hline 10.0 & 10 & As & $\boldsymbol{m}$ & $=20$ & 9.39 & 3.75 & 104.0 & 95.2 & 70.5 & 101.0 & $\bullet$ & 0.0 & 524 & 360 & 236 & 221 & ו1 & 510 & 963 \\
\hline 10.0 & 11 & $\boldsymbol{A x}$ & $\mathbf{m}$ & 50 & 9.39 & 3.75 & 193.3 & 50.0 & 60.0 & 187.6 & $\bullet .0$ & 0.0 & ses & 302 & 242 & 226 & 724 & 535 & 175 \\
\hline 10. & 12 & $\mathbf{A L}$ & $m$ & $=20$ & 9.39 & 3.75 & 202.5 & 53.5 & อ1. 7 & 107.0 & $\bullet . \bullet$ & $\bullet .0$ & $6 e n$ & 390 & 240 & 231 & 737 & 550 & 106 \\
\hline 16.0 & 13 & as & $\boldsymbol{n}$ & $\omega 0$ & 9.39 & 3.75 & 213.9 & 59.0 & 04.0 & 107.0 & $\cdot$. & $\bullet . \bullet$ & 612 & 983 & 253 & 236 & 745 & 561 & ass \\
\hline 10.0 & 20 & $\mathbf{N}$ & $\boldsymbol{n}$ & $=0$ & 9.38 & 3.75 & 201.2 & 66.7 & 99.9 & 101.0 & 2.0 & 0.25 & 630 & 936 & 248 & 226 & 799 & 626 & 561 \\
\hline 10.0 & 21 & $\boldsymbol{A x}$ & $\mathbf{m}$ & $=20$ & 5.39 & 3.75 & 296.8 & 60.2 & 108.5 & 187.0 & 2.0 & 0.25 & 644 & 043 & 252 & 228 & ees & 634 & 567 \\
\hline 10.0 & 22 & $\mathbf{A L}$ & $\mathbf{m}$ & 0 & 9.31 & 3.75 & 310.2 & 70.6 & 103.5 & 101.6 & 2.0 & 0.25 & 646 & 987 & 2se & 230 & 0 es & 630 & 571 \\
\hline 10. & 23 & $\boldsymbol{A s}$ & $\boldsymbol{n}$ & $\infty 0$ & 9.39 & 3.75 & 318.8 & 72.1 & res. & 181. & 2.0 & 0.25 & 652 & (53 & 237 & 233 & 014 & 646 & 576 \\
\hline 10.0 & 13 & $\mathbf{A L}$ & च & $=0$ & 3.52 & 3.47 & 106.4 & 54.0 & 11.7 & 177.5 & 2.0 & 0.25 & set & 390 & 235 & 217 & 204 & set & 503 \\
\hline 10.0 & 18 & $\mathbf{s}$ & - & $=20$ & 2.52 & 3.47 & 897.0 & 56.9 & 79.9 & 171.5 & 2.6 & 0.25 & 60 & $3=0$ & 239 & 221 & 790 & 610 & 530 \\
\hline 10.0 & 15 & $\mathbf{x}$ & - & $\infty$ & 2.52 & 3.47 & 206.2 & 50.7 & 01.7 & 177.5 & 2.0 & e.2s & 61s & 007 & 243 & 220 & 790 & 620 & 597 \\
\hline 10.0 & 15 & $\mathbf{A}$ & v & $n 20$ & 2.52 & 3.67 & 216.1 & 60.6 & 01.6 & 172.5 & 2.0 & 0.25 & 621 & 015 & 247 & 227 & ves & 629 & 664 \\
\hline 10.0 & 24 & $\boldsymbol{x}$ & - & $=20$ & 2.52 & 3.67 & 209.5 & 73.5 & 96.5 & 177.5 & 2.0 & e.ds & 666 & 971 & 273 & 240 & ess & $6: x$ & 649 \\
\hline 10.0 & 25 & as & - & $=20$ & 2.52 & 3.67 & 294.2 & 74.6 & 99.6 & 171.5 & 3.0 & 0.25 & 667 & 972 & 260 & 243 & 66 & 702 & 664 \\
\hline 10.0 & 26 & $\mathbf{N}$ & 0 & 120 & 2.52 & 3.67 & 306.9 & 76.0 & 101.0 & 177.5 & 3.0 & 1.25 & 672 & 470 & 27 & 245 & 069 & 109 & ces \\
\hline 10.0 & 27 & at & - & 120 & 2.52 & 3.01 & 315.9 & 21. & 102.0 & 177.5 & 3.0 & 0.25 & 676 & 404 & 274 & 240 & 614 & is & 613 \\
\hline
\end{tabular}




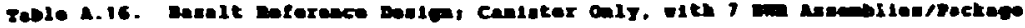

\begin{tabular}{|c|c|c|c|c|c|c|c|c|c|c|c|c|c|c|c|c|c|c|c|}
\hline \multirow[b]{2}{*}{ rones } & \multirow{2}{*}{ cons. } & \multicolumn{3}{|c|}{ manerase } & \multicolumn{2}{|c|}{ In rumeses } & \multirow{2}{*}{$\begin{array}{l}\text { care } \\
\text { wexers } \\
\text { (reters) }\end{array}$} & \multirow{2}{*}{ ID } & \multicolumn{3}{|c|}{ 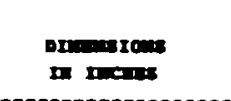 } & \multirow{2}{*}{ In. } & \multicolumn{4}{|c|}{ 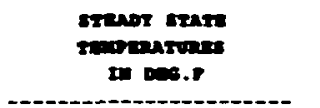 } & \multicolumn{3}{|c|}{ 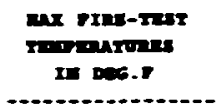 } \\
\hline & & Inex & can. & ס & chin. & סיר: & & & $\infty$ & עיח & Trin. & & $\begin{array}{l}\text { rote } \\
\text { pri }\end{array}$ & $\begin{array}{l}\text { Imese } \\
\text { wart }\end{array}$ & $\cos$ & $\begin{array}{l}\cos . \\
\sin x .\end{array}$ & rix & $\begin{array}{l}\text { toter } \\
\text { ant }\end{array}$ & פוזר \\
\hline 10. & 11 & AL & ne & 120 & 4.62 & 0.25 & 1e9.5 & 30.0 & 75.0 & 197.3 & $\bullet . \bullet$ & 0.0 & 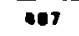 & 323 & 219 & 207 & 628 & 4อ4 & 460 \\
\hline 10.0 & 12 & AL & $\mathbf{P e}$ & $\mathbf{2 0}$ &. .62 & 0.25 & 198.9 & 32.5 & 77.5 & 197.3 & $\bullet .0$ & 0.0 & ess & 33 & 224 & 211 & 638 & 496 & 465 \\
\hline 10.0 & 13 & 46 & be & 120 & 5.62 & - .25 & 210.6 & 54.0 & 79.0 & 197.3 & $\bullet .0$ & 0.0 & see & 340 & 220 & 210 & gis & 504 & 476 \\
\hline 10.6 & 16 & $\mathbf{A L}$ & 10 & 120 & 4.02 & 4.25 & 222.1 & 56.9 & 12.0 & 197.3 & $\bullet .0$ & 6.0 & 506 & 307 & 231 & 210 & 6S1 & 312 & 902 \\
\hline te. & 21 & AL & $\mathbf{p e}$ & 120 & 9.62 & 4.25 & 294.2 & 68.2 & 93.3 & 197.3 & $\bullet . \bullet$ & $\bullet . \bullet$ & sas & 394 & 255 & 239 & 697 & 360 & 524 \\
\hline 10.0 & 22 & at & 80 & 220 & 0.62 & 4.25 & 301.6 & 70.6 & 95.1 & 197.3 & $\bullet .0$ & $\bullet .0$ & 547 & 357 & 257 & 240 & 69 & 371 & 527 \\
\hline 10.0 & 23 & AL & - & $=20$ &. .62 & 0.25 & 313.3 & 72.1 & 91.2 & 197.3 & $\bullet$. & 0.0 & 532 & 403 & 260 & 203 & 704 & 371 & 532 \\
\hline 10.0 & 25 & at & $\mathbf{s}$ & 120 & 4.62 & 4.25 & 322.5 & 73.5 & 94.5 & 197.3 & $\bullet . \bullet$ & 0.0 & 557 & ses & 263 & 245 & 110 & 524 & 537 \\
\hline 18.6 & s & $\mathbf{A L}$ & $n$ & $=20$ & 9.39 & 3.75 & 105.3 & 16.9 & 76.2 & 201.5 & $\bullet . \bullet$ & $\bullet .0$ & ass & 290 & 200 & 190 & set & 130 & 003 \\
\hline 18.0 & 10 & at & 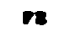 & $\mathbf{2 2 0}$ & 9.39 & 3.75 & 191.3 & 69.2 & 78.5 & 208.5 & $\bullet .1$ & $\bullet$. & 513 & 1er & 209 & 190 & 591 & 142 & 12 \\
\hline 10.0 & 11 & $\boldsymbol{M}$ & 1 & $=200$ & 9.39 & 3.75 & 206.2 & se.e & 16.6 & 201.5 & 0.0 & 0.0 & 902 & 317 & 214 & 203 & 602 & 456 & 422 \\
\hline 10.0 & 12 & $\mathbf{A b}$ & $\boldsymbol{m}$ & 120 & 9.39 & 3.15 & 216.0 & 52.5 & 01.7 & 201.5 & $\bullet .0$ & 0.0 & nes & 327 & 210 & 206 & 612 & ase & 411 \\
\hline 10.0 & 19 & $\Delta$ & $\mathbf{n e}$ & 120 & 9.39 & 3.75 & 207.3 & 64.6 & 93.7 & 201.5 & 0.0 & 0.0 & 531 & 370 & 244 & 225 & 665 & 532 & 480 \\
\hline 10.0 & 20 & A & $\mathbf{n}$ & $\square 20$ & 9.39 & 3.75 & 300.3 & 66.7 & 95.9 & 201.5 & 0.0 & 0.0 & 534 & 302 & 201 & 231 & 663 & 531 & 18 \\
\hline 10.0 & 21 & $\boldsymbol{A L}$ & $\mathbf{m}$ & 1120 & 9.39 & 3.75 & 310.6 & 68.2 & 97.5 & 201.5 & 0.0 & 0.0 & 538 & 307 & 249 & 233 & 674 & 594 & tes \\
\hline 10.0 & 22 & at & $\mathbf{r}$ & 120 & 9.39 & 3.75 & 324.5 & 70.6 & 99.9 & 201.5 & 0.0 & 0.0 & 542 & 390 & 252 & 235 & 511 & 591 & 193 \\
\hline 10.0 & 12 & $\boldsymbol{A L}$ & $\mathbf{v}$ & 1020 & 2.52 & 3.67 & 104.0 & 52.5 & 71.1 & 191.2 & 0.0 & 0.0 & อง & 330 & 211 & 219 & 648 & 505 & 494 \\
\hline 10.0 & 13 & AL & 0 & 1720 & 2.52 & 3.47 & 195.3 & 34.0 & 73.1 & 191.2 & 0.0 & 0.0 & ses & 345 & 233 & 222 & 653 & 511 & 501 \\
\hline 10.0 & 14 & $\mathbf{A}$ & o & 120 & 2.52 & 3.67 & 206.4 & 56.5 & 75.9 & 131.2 & 0.0 & 0.0 & 510 & 352 & 239 & 223 & 661 & 524 & 301 \\
\hline 10.0 & 15 & AL & $\mathbf{0}$ & miso & 2.52 & 1.97 & 216.1 & 58.7 & 77.7 & 191.2 & 0.0 & 0.0 & 516 & 359 & 243 & 229 & 669 & 533 & 514 \\
\hline 10.0 & 22 & at & $\mathbf{0}$ & $\mathbf{n 2 0}$ & 2.52 & 3.67 & 205.1 & 10.6 & 09.6 & 191.2 & 0.0 & 0.0 & 551 & $\$ 02$ & 265 & 249 & 700 & sed & 551 \\
\hline 10.0 & 23 & ab & $\mathbf{0}$ & $m 20$ & 2.52 & 3.4 & 298.7 & 22.1 & 93.1 & 191.2 & 2.0 & 0.25 & 530 & 381 & 235 & 218 & 112 & set & 378 \\
\hline 10.0 & 24 & $\boldsymbol{A L}$ & $\mathbf{0}$ & 120 & 2.52 & 3.67 & 300.7 & 13.5 & 96.5 & 181.2 & 2.0 & 0.25 & 530 & 386 & 237 & 220 & 717 & 581 & 503 \\
\hline 10.0 & 25 & at & $\mathbf{v}$ & $m 20$ & 2.52 & 3.97 & 316.5 & 74.6 & 97.6 & 191.2 & 2.3 & 0.25 & $\operatorname{sen}$ & 392 & 240 & 222 & 720 & 590 & see \\
\hline
\end{tabular}




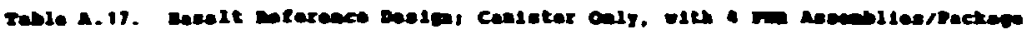

\begin{tabular}{|c|c|c|c|c|c|c|c|c|c|c|c|c|c|c|c|c|c|c|c|}
\hline \multirow[b]{2}{*}{$\operatorname{mat}_{\operatorname{mes}}$} & \multirow{2}{*}{ cas. } & \multicolumn{3}{|c|}{ Mrares } & \multicolumn{2}{|c|}{ 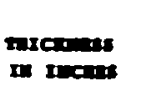 } & \multirow{2}{*}{ 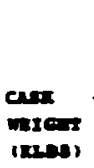 } & \multirow{2}{*}{ 10 } & \multicolumn{3}{|c|}{ Dr in rens } & \multirow[b]{2}{*}{ rx. } & \multicolumn{4}{|c|}{ 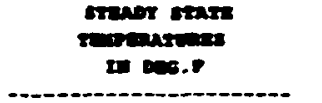 } & \multicolumn{3}{|c|}{ 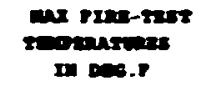 } \\
\hline & & nux & ans. & $\operatorname{men}$ & $\operatorname{con}$ & का & & & $\infty$ & 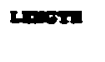 & ve. & & ine & $\begin{array}{l}\min \\
\operatorname{mex}\end{array}$ & andas & care. & ner & $\begin{array}{l}\text { rwast } \\
\text { wrt }\end{array}$ & expan \\
\hline 10.0 & 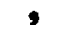 & as & $\mathbf{n}$ & 120 & 3.80 & 0.25 & 170.6 & 52.7 & 77.5 & 103.2 & 6.6 & $\bullet .0$ & 642 & 100 & 255 & 230 & 792 & sta & 526 \\
\hline 10.0 & 10 & $\boldsymbol{A L}$ & $\mathbf{n}$ & $=200$ & 3.00 & 0.25 & 191.2 & ss.t & ee. 1 & 103.2 & 6. & 0.0 & 653 & 110 & 262 & 248 & nea & 593 & 537 \\
\hline 10.0 & 11 & $\mathbf{A}$ & $n$ & $m 20$ & 3.91 & 1.25 & 205. & 57.1 & es. & 103.3 & 2.6 & 0.25 & cas & $\operatorname{sen}$ & 236 & 211 & 120 & 610 & 571 \\
\hline 10.0 & 12 & $\mathbf{M}$ & $\mathbf{n}$ & $m 20$ & 3.53 & 0.25 & 216.0 & s9.0 & 67.9 & 103.3 & 2.0 & 0.25 & ess & 917 & 242 & 221 & 633 & 626 & sez \\
\hline 10.0 & 13 & $\mathbf{A S}$ & $\mathbf{n}$ & 120 & 3.96 & 0.25 & 230.4 & 61.6 & 10.5 & 183.4 & 2.0 & 0.25 & 662 & 126 & 245 & 225 & sec & 636 & ses \\
\hline 10.8 & 17 & as & $\mathbf{n}$ & $=0$ & 0.01 & 0.25 & 201.0 & re.s & 99.6 & 103.6 & 2.0 & 0.25 & 690 & 962 & 263 & 230 & 41 & 676 & 610 \\
\hline 10.0 & 10 & $\mathbf{n}$ & $n$ & 20 & 0.67 & 0.25 & 293.3 & 72.11 & 101.6 & 183.6 & 2.0 & 0.25 & 697 & 97 & 267 & 241 & ere & ces & $6250^{\circ}$ \\
\hline 10.0 & 19 & $\boldsymbol{N}$ & $\mathbf{n}$ & 100 & 0.07 & 0.25 & 296.8 & 22.41 & 101.6 & 103.6 & 2.0 & 0.25 & res & 486 & 273 & 246 & ess & 106 & 6370 \\
\hline 10.0 & 20 & as & $\mathbf{n}$ & 1020 & $\bullet .6$ & 0.25 & 310.9 & is. & 100.1 & 103.6 & 2.0 & 0.25 & 113 & 41 & 216 & 246 & ese & וז & Gezo \\
\hline 10.0 & 21 & $\mathbf{a b}$ & $\boldsymbol{n}$ & $=20$ & 4.07 & 0.25 & 323.2 & 76.01 & 107.9 & 103.6 & 3. & 0.25 & 115 & 483 & 212 & 244 & 901 & 721 & 6350 \\
\hline 10.0 & • & as & $\boldsymbol{n}$ & $=20$ & 9.24 & 3.15 & 176.2 & $\bullet$ & 11.3 & 101.5 & $\bullet .0$ & 0.6 & 630 & Jes & 203 & 227 & 160 & sed & 47 \\
\hline 10.0 & 9 & $\boldsymbol{a r}$ & $r$ & 100 & 9.24 & 3.15 & 195.2 & 52.7 & $e r .7$ & 101.5 & 0.0 & 0.0 & 636 & 303 & 246 & 232 & 166 & 549 & 4e7 \\
\hline 10.0 & 10 & $\mathbf{A s}$ & $\mathrm{n}$ & $n 20$ & 9.24 & 3.75 & 200.3 & 53.4 & 94.3 & 101.5 & 0.1 & 0. & 647 & 406 & 2ss & 230 & 179 & scs & 189 \\
\hline 10.0 & 11 & $\boldsymbol{n}$ & $\boldsymbol{n}$ & $n 20$ & 9.20 & 3.15 & 210.7 & 57.1 & 06.1 & 101.5 & $\bullet . \bullet$ & $\bullet .0$ & 650 & 021 & 262 & 249 & 194 & 5ea & 512 \\
\hline 10.0 & 12 & $\boldsymbol{u}$ & $m$ & $=20$ & 9.32 & 3.75 & 230.1 & ss.t & 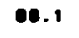 & 101.6 & 0.0 & $\bullet .0$ & 669 & 135 & 269 & 250 & 106 & 600 & 524 \\
\hline 10.0 & 15 & $\mathbf{A b}$ & n & aso & 9.04 & 3.15 & 275 - 6 & 66.0 & 9s.t & 101.9 & 2.0 & 0.25 & 672 & 130 & 249 & 221 & 130 & 620 & 562 \\
\hline 10.0 & 16 & $\boldsymbol{s}$ & n & $=20$ & 9.44 & 3.15 & 280.1 & 60.2 & 101.6 & 101.5 & 2.3 & 0.25 & 67 & 967 & 253 & 230 & 130 & 639 & 580 \\
\hline 10.0 & 17 & $a \mathbf{b}$ & $m$ & $=20$ & 9.96 & 3.75 & 301.0 & 10.5 & tes.9 & ter.s & 2.0 & 0.25 & ces & iss & 251 & 233 & ens & 640 & 571 \\
\hline 10.0 & 10 & $a$ & $n$ & 520 & 3.94 & 3.75 & 313.3 & 12.4 & 105.0 & 101.9 & 2.0 & 0.25 & 691 & 463 & 260 & 236 & 053 & 650 & sed \\
\hline 10.0 & 19 & as. & $\boldsymbol{m}$ & $=20$ & 9.00 & 3.15 & 316.7 & 12.4 & 105.0 & 101.8 & 2.0 & 0.25 & 103 & 170 & 266 & 240 & 060 & 671 & ses \\
\hline 10.0 & 10 & as & 0 & $=20$ & 2.81 & 3.47 & 179.0 & 55.4 & 10.1 & 171.2 & 2.0 & 0.25 & 636 & 383 & 221 & 219 & 16 & 604 & see \\
\hline 10.0 & 31 & at. & v & 120 & 2.43 & 3.07 & 109.5 & 37.1 & 79.3 & 171.3 & 2.0 & 0.25 & $\sec$ & 4อง & 243 & 224 & 031 & 623 & 600 \\
\hline 10.0 & 12 & $\boldsymbol{A L}$ & 0 & $=20$ & 2.44 & 3.47 & 200.1 & 59.0 & 01. & 171.3 & 2.0 & 0.25 & cse & 120 & 245 & 229 & 043 & 639 & 610 \\
\hline 10.0 & 13 & as & 0 & $=20$ & 2.16 & 3.47 & 213.1 & 61.6 & 04.4 & 171.3 & 2.0 & 0.25 & cos & 430 & 258 & 233 & esi & 695 & 617 \\
\hline 10.0 & 14 & as & 0 & $=20$ & 2.00 & 3.47 & 226.1 & 64.0 & e6. & 121.4 & 2.0 & 0.23 & 672 & 439 & 250 & 236 & ese & 6so & 624 \\
\hline 10.0 & is & $\boldsymbol{\mu L}$ & $\mathbf{v}$ & -20 & 2.36 & 1.07 & 3. & 12.4 & 92.5 & 171.5 & 3.0 & 0.25 & 707 & 604 & 272 & 296 & 906 & 110 & 672 \\
\hline 10.0 & 20 & $\boldsymbol{\alpha L}$ & 0 & 120 & 2.56 & 3.41 & 293.1 & 15.0 & 100.1 & 117.3 & 3.0 & 0.25 & 11 & nes & 273 & 290 & 909 & 123 & 676 \\
\hline 10.0 & 21 & al & 0 & 120 & 2.36 & 3.47 & 304.9 & 16.0 & 103.0 & m.s & 0.0 & 0.25 & 115 & 193 & 275 & 291 & 910 & 133 & 690 \\
\hline 10.0 & 22 & $\mu$ & 0 & $=20$ & 2.56 & 3.41 & 319.1 & 15.5 & 106.5 & 171.5 & 4.0 & 0.25 & 110 & 491 & 271 & 249 & 920 & 135 & 693 \\
\hline 10.0 & a) & al & 0 & 120 & 2.56 & 3.41 & 331.5 & 01.2. & 110.2 & 117.5 & 5.0 & 0.25 & 723 & 503 & 270 & 250 & 929 & 196 & 106 \\
\hline
\end{tabular}




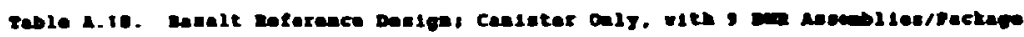

\begin{tabular}{|c|c|c|c|c|c|c|c|c|c|c|c|c|c|c|c|c|c|c|c|}
\hline \multirow[b]{2}{*}{ man } & \multirow{2}{*}{ cor. } & \multicolumn{3}{|c|}{ meriarats } & \multicolumn{2}{|c|}{$\begin{array}{l}\text { grouges } \\
\text { In Incmest }\end{array}$} & \multirow{2}{*}{$\begin{array}{l}\text { case } \\
\text { weres } \\
\text { tensi }\end{array}$} & \multicolumn{5}{|c|}{ 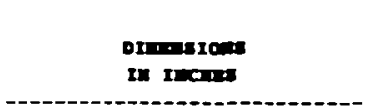 } & \multicolumn{4}{|c|}{ 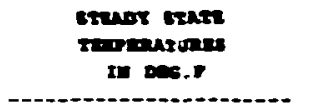 } & \multicolumn{3}{|c|}{ 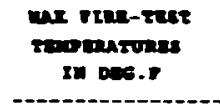 } \\
\hline & & twate & can. & ס्रा & ean. & Din & & 10 & $\infty$ & L"तTI & $\mathbf{r}$ & mim. & vill & $\begin{array}{l}\text { Imox } \\
\text { wart }\end{array}$ & סוחרו & cans & max & $\begin{array}{l}\text { Imax } \\
\text { mane }\end{array}$ & $\cos _{\cos }$ \\
\hline 10.0 & - & $\mathbf{N}$ & $\omega$ & 120 & 3.91 & 4.25 & 121.6 & 48.3 & 73.1 & 191.0 & 0.0 & $\bullet .0$ & sod .. & -320 & 217 & 205 & 647 & 483 & 450 \\
\hline 10.0 & 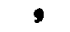 & $\boldsymbol{N 2}$ & $\mathbf{n}$ & 120 & 3.00 & 4.25 & 190.0 & 52.7 & 77.5 & 197.0 & 0.0 & 0.0 & 510 & 327 & 221 & 209 & 650 & 487 & 46 \\
\hline 10.0 & 10 & $\boldsymbol{N}$ & $\mathbf{s e}$ & 120 & 3.0 & 4.25 & 200.1 & 55.1 & 20.1 & 197.0 & $\bullet . \bullet$ & 0.0 & 510 & 337 & 226 & 214 & 660 & อ9 & 170 \\
\hline 10.0 & 11 & $\boldsymbol{N}$ & $\infty$ & no & 3.81 & 4.25 & $2 \div 4.7$ & 57.1 & 11.9 & 191.1 & $\bullet .6$ & 6 & 520 & 349 & 232 & 213 & 672 & 515 & 485 \\
\hline 10.0 & 16 & $\boldsymbol{\mu L}$ & $\mathbf{m}$ & $=20$ & 0.00 & 0.23 & 280.4 & 60.2 & 93.3 & 197.3 & $\bullet . \bullet$ & 0.0 & 561 & 390 & 253 & 237 & זו & 563 & 521 \\
\hline 10.0 & 11 & $\boldsymbol{n L}$ & $\mathbf{w}$ & 20 & 0.07 & 1.25 & 294.6 & 70.5 & 95.6 & 197.4 & 0.6 & 0.0 & 366 & 396 & 257 & 240 & 716 & 570 & 526 \\
\hline 10.0 & 11 & $\boldsymbol{N}$ & $\mathbf{m}$ & $=20$ & 0.07 & 0.25 & 306.6 & 12.0 & 97.6 & 197.4 & 0.0 & 0.0 & 572 & 103 & 261 & 243 & 723 & 570 & 532 \\
\hline 10.0 & 19 & $\boldsymbol{N L}$ & no & no & 0.07 & 0.25 & 110.2 & 12.6 & 97.6 & 197.4 & 0.0 & C.0 & 382 & 116 & 266 & 240 & 737 & sos & 543 \\
\hline 10.0 & 26 & $\boldsymbol{A L}$ & $\infty$ & $=0$ & 4.07 & 4.25 & 325.1 & 75.0 & 100.1 & 197.4 & 0.0 & 0.0 & 586 & 120 & 268 & 250 & 741 & 599 & 547 \\
\hline 10.0 & 1 & ab & $\boldsymbol{n}$ & 120 & 9.24 & 3.15 & 168.0 & 14.0 & 22.9 & 201.2 & 0.0 & 0.0 & 494 & 307 & 207 & 197 & 614 & 945 & 910 \\
\hline 10.0 & $\bullet$ & $\boldsymbol{M}$ & $\mathrm{r}$ & $\pi 20$ & 9.24 & 3.75 & 180.1 & 48.3 & 71.3 & 201.2 & 0.0 & 0.0 & 500 & 310 & 212 & 201 & 620 & 453 & 115 \\
\hline 10.0 & 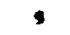 & al & $\mathbf{v}$ & 120 & 9.24 & 3.75 & 208.3 & 52.7 & 1.7 & 201.2 & 0.0 & 0.0 & 505 & 321 & 215 & 205 & 625 & 160 & 126 \\
\hline 10.0 & 10 & $\boldsymbol{N}$ & $\boldsymbol{r}$ & 120 & 9.24 & 3.75 & $222 . ?$ & 55.4 & 64.3 & 201.2 & 0.0 & 0.0 & 513 & 331 & 221 & 209 & 635 & 3 & 136 \\
\hline 10.0 & 10 & $\boldsymbol{N L}$ & $n$ & \pm 20 & 9.40 & 3.75 & 275.1 & 60.0 & 03.3 & 201.6 & 0.0 & 0.0 & 503 & 360 & 200 & 225 & 673 & $\operatorname{sis}$ & 91 \\
\hline 10.0 & 15 & $\boldsymbol{N}$ & 5 & $\mathbf{m 3 0}$ & 0.44 & 3.75 & 208.1 & 66.0 & 25.4 & 201.6 & 0.0 & 0.0 & 550 & 376 & 244 & 220 & 601 & 529 & 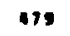 \\
\hline 10.0 & 16 & $\boldsymbol{\mu L}$ & $\mathbf{m}$ & 120 & 9.44 & 3.75 & 301.2 & Ga.2 & 57.6 & 201.6 & 0.0 & 0.0 & 556 & 383 & 240 & 232 & 6et & 330 & 106 \\
\hline 10.0 & 17 & $\boldsymbol{N}$ & $\mathbf{v}$ & $\mathbf{1 2 0}$ & 3.44 & 3.75 & 315.2 & 70.5 & 99.9 & 201.6 & 0.0 & 0.0 & 561 & 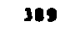 & 251 & 230 & 699 & 546 & 191 \\
\hline 10.0 & 18 & $\boldsymbol{\mu}$ & $n$ & $=20$ & 9.44 & 3.75 & 321.7 & 72.4 & 101.0 & 201.6 & 0.0 & 0.0 & 366 & 396 & 254 & 230 & 101 & ss4 & 990 \\
\hline 10.0 & $\bullet$ & $\boldsymbol{N}$ & 0 & mo & 2.41 & 3.47 & 175.4 & 52.7 & 11.5 & 151.0 & 0.0 & 0.0 & 514 & 331 & 220 & 216 & 660 & 499 & ses \\
\hline 10.0 & 10 & dI & ס & $\mathbf{2 0}$ & 2.41 & 3.47 & 108.3 & 55.4 & 24.1 & 191.0 & 0.0 & 0.0 & 522 & 341 & 233 & 221 & 670 & 511 & ass \\
\hline 10.0 & 11 & AI & 0 & 120 & 2.43 & 3.67 & 190.4 & 31.1 & 75.9 & 191.1 & 0.0 & 0.0 & 531 & 354 & 239 & 226 & cos & 527 & 510 \\
\hline 10.0 & 12 & $\boldsymbol{N}$ & 0 & 120 & 2.94 & 3.47 & 209.6 & 59.0 & 77.0 & is1.1 & 0.0 & 0.0 & 500 & 364 & 245 & 231 & 694 & 540 & 519 \\
\hline 10.0 & 13 & $\mathbf{N}$ & 0 & $m 20$ & 2.96 & 3.17 & 223.3 & 61.6 & 10.4 & 191.1 & 0.0 & 0.0 & 546 & 372 & 206 & 235 & 100 & see & 526 \\
\hline 10.0 & 17 & $\boldsymbol{a r}$ & $\mathbf{0}$ & $\mathbf{1 2 0}$ & 2.53 & 3.47 & 275.1 & 70.5 & 69.5 & 191.3 & 0.0 & 0.0 & 571 & 901 & 265 & 246 & 126 & 501 & 951 \\
\hline 10.0 & 10 & $a L$ & $\mathbf{0}$ & $=20$ & 2.54 & 3.67 & 292.5 & 72.4 & 15.3 & 191.3 & 2.0 & 0.25 & 5ss & 382 & 233 & 210 & 731 & ses & 579 \\
\hline 10.0 & 19 & $\boldsymbol{A L}$ & 0 & 120 & 2.56 & 3.97 & 296.0 & 72.9 & 15.5 & 191.3 & 2.0 & 0.25 & 564 & 394 & 240 & 222 & 746 & 603 & see \\
\hline 10.0 & 20 & $\boldsymbol{N L}$ & 0 & $\mathbf{2 0}$ & 2.36 & 3.67 & 311.3 & 75.0 & 10.1 & 191.3 & 2.0 & 0.25 & 561 & 391 & 242 & 223 & 740 & 606 & 592 \\
\hline 10.0 & 21 & $\mathbf{A L}$ & 0 & $=20$ & 2.54 & 3.67 & 322. & 76.0 & 19.0 & 191.3 & 2.0 & 0.25 & 572 & 403 & 244 & 226 & 754 & 612 & 597 \\
\hline
\end{tabular}




\section{INTERNAL DISTRIBUTION}

$\begin{aligned} \text { 1. } & \text { W. D. Box } \\ \text { 2-6. } & \text { J. A. Bucholz } \\ \text { 7. } & \text { W. D. Burch } \\ \text { 8. } & \text { A. G. Croff } \\ \text { 9. } & \text { H. R. Dyer } \\ \text { 10. } & \text { C. W. Forsberg } \\ \text { 11. } & \text { A. R. Irvine } \\ \text { 12. } & \text { W. C. Jordan } \\ \text { 13. } & \text { D. S. Joy } \\ \text { 14. } & \text { J. A. Klein } \\ \text { 15. } & \text { J. V. Pace, III } \\ \text { 16. } & \text { C. V. Parks } \\ \text { 17. } & \text { R. T. Primm, III } \\ \text { 18. } & \text { R. R. Rawl } \\ \text { 19. } & \text { J. P. Renier } \\ \text { 20. } & \text { T. H. Row }\end{aligned}$

$\begin{aligned} \text { 21-25. } & \text { L. B. Shappert } \\ 26 . & \text { W. C. Stoddart } \\ 27 . & \text { J. S. Tang } \\ 28 . & \text { J. T. Thomas } \\ 29 . & \text { C. C. Webster } \\ 30 . & \text { R. M. Westfall } \\ 31 . & \text { G. E. Whitesides/R. P. Leinius/ } \\ \text { 32. } & \text { Central Research Library } \\ 33 . & \text { Central Research Library } \\ 34 . & \text { ORNL-Y-12 Technical Library, } \\ & \text { Document Reference Section } \\ \text { 35-36. } & \text { Laboratory Records Department } \\ 37 . & \text { Laboratory Records, ORNL, RC } \\ 38 . & \text { ORNL Patent Office }\end{aligned}$

\section{EXTERNAL DISTRIBUTION}

39. George Allen, Jr., Sandia National Laboratories, Div. 5323, P. O. Box 5800, Albuquerque, NM 87185

40. R. Barner, U.S. Department of Energy, Nevada Operations Office, P.O. Box 14100, Las Vegas, NV 89114

41. L. Barrett, U.S. Department of Energy, 1000 Independence Ave., R W-33, Washington, DC 20585

42. W. P. Barthold, Barthold and Associates, P. O. Box i 1730, Albuquerque, NM 87192

43. E. Benz, Weston Corporation, 230! Research Blvd., Rockville, MD 20850

44. W. Bixby, U.S. Department of Energy, Rt. 441 South, Bldg. 400, Middletown, PA 17057

45. C. Boggs-Mayes, U.S. Department of Energy, Chicago Operations Office, $9800 \mathrm{~S}$. Cass Ave.,Argonne. IL 60439

46-50. P. Bolton, Weston Corporation, 2301 Research Blvd., ?ockville, MD 20850

51. E. Burton, U.S. Department of Energy, 1000 Independence Ave., RW-25, Washington, DC 20585

52. D. Carrell, Rockwell Hanford (BWIP), 1100 Jadwin, P. O. Box 800, Richland, WA 99352

53. S. Chu, U.S. Department of Transportation, Resources,and Special Programs Adm., DMT-60, Washington, DC 20590

54. N. Dayem-Sheaks, Weston Corporation, 2301 Research Blvd., Rockville, MD 20850

55. S. Denny, U.S. Department of Energy, 1000 Independence Ave., RW-33, Washington, DC 20585

56. L. Friel, Western Interstate Energy Board, Stapleton Plaza, 3333 Quebec St., Denver, CO 80207

57. R. Gale, U.S. Department of Energy, 1000 Independence Ave., RW-40, Wasi..ngton, DC 20585

58. K. Golliher, U.S. Department of Energy, Albuquerque Cperations Office, P. O. Box 5400, Albuquerque, NM 87115

59. S. Gupta, Battelle Project Management Division, 505 King Ave., Columbus, $\mathrm{OH} 43201$

60. R. Halstead, Radioactive Waste Review Board, 3 South Pinckney St., 921 Tenney Bldg., Madison, WI 53702

61. R. Hannon, U.S. Department of Transportation, Resources, and Specici! !rograms Adm., DMT-60, Washington, DC 20590 
62-64. M. Heiskell, U.S. Department of Energy, Oak Ridge Operations Office, G-24, P. O. Box E, Oak Ridge, TN 37831

65. K. Henry, Rockwell Hanford (BWIP), 1100 Jadwin, P. O. Box 800, Richland, WA 99352

66. R. Izatt, U.S. Department of Enorgy, Richlend Operations Office, 825 Jadwin Ave., P. O. Box 550, Richland, WA 99352

67. Robert Jones, P. O. Box 1510, Los Gatos, CA 95031-1510

68. C. Kimm, Battelle Project Management Division, 505 King Ave., Columbus, ()H 43201

69. D. Langstaff, U.S. Department of Energy, Richland Operations Office, 825 Jadwin Ave., P. O. Box 550, Richland, WA 99352

70. D. Larson, Western Interstate Energy Board, Stapleton Plaza, 3333 Quebec St., Denver, CO 80207

71. J. A. Lenhard, U. S. Department of Energy, Oak Ridge Operations, Oak Ridge, TN 37831

72. L. Marks, U.S. Department of Energy, 1000 Independence Ave., RW-33, Washington, DC 20585

73. Marilyn McNabb, Nebraska Energy Office, State Capitol, Ninth Floor, P. O. Box 95085, Linioln, NE 68509

74. G. W. McNair, Battelle Pacific Northwest Laboratory, Battelle Blvd., P. O. Box 999, Richland, WA 99352

75. J. Neff, U.S. Department of Energy, Salt Repository Program Office, 505 King Ave., Columbus, $\mathrm{OH} 43201$

76. Bim Oliver, High Level Nuclear Waste Office, $355 \mathrm{~W}$. North Temple, 3 Triad Center, Suite 330, Salt Lake City, UT 84180-1203

77. W. Pardue, Battelle Project Management Division, Office of Crystalline Repository Development, 9800 S. C.ass Ave., Bldg. 360, Argonne, IL 50439

78. G. Parker, U.S. Department of Energy, 1000 Independence Ave., RW-25, Washington, DC 20585

79. J. Parker, Office of High Level Nuclear Waste Management, 5826 Pacific Ave., Lacey, WA 98504

80. R. W. Peterson, Battelle Project Management Division, 505 King Ave., Columbus, OH 43201

81. R. Philpott, U.S. Department of Energy, 1000 Independence Ave., RW 33, Washington, DC 20585

82. R. B. Pope, IAEA, Wagramerstrasse 5, Rm. A-2744, P. O. Box 200, A-1400, Vienna. Austria

83. M. Rahimi, Weston Corporation, 2301 Research Blvd., Rockville, MD 20850

84. Marvin Resnixoff, P. O. Box 92, Blairstown, NJ 07825

85. J. N. Rogers, S india National Laboratories, Div. 8474, Livermore, CA 94550

86. Tom Sanders, vandia National Laboratories, Div. 6323, P. O. Box 5800, Albuquerque, NM 87185

87. C. Scardino, Science Applications, Inc. (NNWSI), 2769 S. Highland Ave, Las Vegas, NV 89114

88. K. J. Schneider, Battelle Pacific Northwest Laboratory, Battelle Blvd., P. O. Box 999 , Richland, WA 99352

89. C. Toussaint, Weston Corporation, 2301 Research Blvd., Rockville, MD 20850

90. D. Vieth, U.S. Department of Energy, Nevada Operations Office, P.O. Box 14100, Las Vegas, NV 89114

91. J. Williams, U.S. Department of Energy, Salt Repository Program Office, 505 King Ave., Columbus, $\mathrm{OH} 43201$

92-96. E. Wilmot, U.S. Department of Energy, 1000 Independence Ave., Washington, DC 20585 